\title{
EFFECTS OF DRILLING VARIABLES \\ ON BURR PROPERTIES
}

Published September 1976

Project Leader:

L: K. Gillespie

Department 822

Project Team:

R. K. Albright

B. J. Neal

PDO 6984405

Topical Report

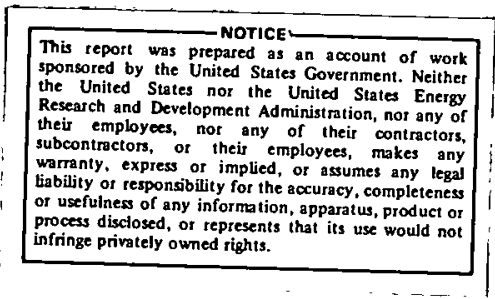

Technical Communications

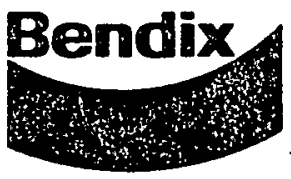

Kansas City
Division 


\section{DISCLAIMER}

This report was prepared as an account of work sponsored by an agency of the United States Government. Neither the United States Government nor any agency Thereof, nor any of their employees, makes any warranty, express or implied, or assumes any legal liability or responsibility for the accuracy, completeness, or usefulness of any information, apparatus, product, or process disclosed, or represents that its use would not infringe privately owned rights. Reference herein to any specific commercial product, process, or service by trade name, trademark, manufacturer, or otherwise does not necessarily constitute or imply its endorsement, recommendation, or favoring by the United States Government or any agency thereof. The views and opinions of authors expressed herein do not necessarily state or reflect those of the United States Government or any agency thereof. 


\section{DISCLAIMER}

Portions of this document may be illegible in electronic image products. Images are produced from the best available original document. 


\title{
EFFECTS OF DRILLING VARIABLES ON BURR PROPERTIES
}

\author{
BDX-613-1502, UNCLASSIFIED Topical Report, Published September \\ 1976
}

Prepared by L. K. Gillespie, D/822, under PDO 6984405

An investigation utilizing 303Se stainless steel, 17-4PH stainless steel, 1018 steel, and 6061-T6 aluminum was conducted to determine the influence of drilling variables in controlling burr size to minimize burr-removal cost and improve the quality and reliability of parts for small precision mechanisms. Burr thickness can be minimized by reducing feedrate and cutting velocity, and by using drills having high helix angles. High helix angles reduce burr thickness, length, and radius, while most other variables reduce only one of these properties. Radial-lip drills minimize burrs from 303Se stainless steel when large numbers of holes are drilled; this material stretches 10 percent before drill-breakthrough. Entrance burrs can be minimized by the use of subland drills at a greatly increased tool cost. Backup-rods used in cross-drilled holes may be difficult to remove and may scratch the hole walls.

WPC-dvh

This report was prepared as an account of work sponsored by the United States Government. Neither the United States nor the United States Energy Research and Development Administration, nor any of their employees, nor any of their contractors, subcontractors, or their employees, makes any warranty, express or implied, or assumes any legal liability or responsibility for the accuracy, completeness or usefulness of any information, apparatus, product or process disclosed, or represents that its use would not infringe privately owned rights.
THE BENDIX CORPORATION

KANSAS CITY DIVISION

P.O. BOX 1159

KANSAS CITY, MISSOURI 64141

A prime contractor for the United States Energy Research and Development Administration Contract Number E(29-1)-613 USERDA 


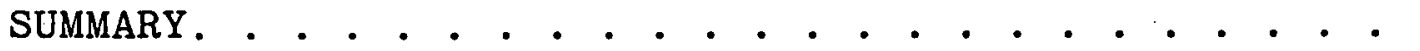

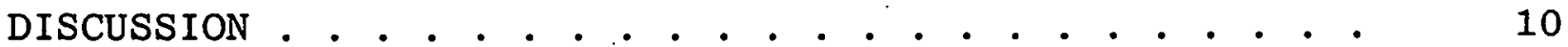

SCOPE AND PURPOSE. . . . . . . . . . . . . . . . . . 10

PRIOR WORK . . . . . . . . . . . . . . . . . 10

ACTIVITY . . . . . . . . . . . . . . . . . . 10

Effects of Helix Angle, Diameter, Velocity, Point Geometry, and Workpiece Material . . . . . .

Effects of Feedrate, Spindle Speed, and Workpiece Material With Subland Drills . . . . . . 16

Effect of Drill Wear . . . . . . . . . . . . . 17

Burr Minimization in Cross-Hole Drilling . . . . . . 25

The Formation of Burrs at Drill-Breakthrough . . . . 27

The Appearance of Drill-Exit Burrs . . . . . . . . . 28

Analysis of Recently Published Reports . . . . . . 30

Production Implications. . . . . . . . . . . . . 37

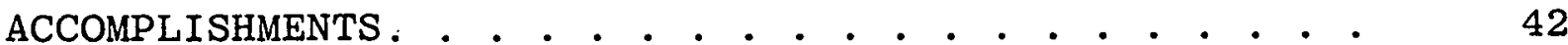

FUTURE WORK. . . . . . . . . . . . . . . . . . . . 42

REFERENCES . . . . . . . . . . . . . . . . . . . . . . 64

APPENDIX. TABULAR DATA ON BURRS OBTAINED FROM
STUDY OF DRILLING VARIABLES . . . . . . . . . . . $\quad 67$

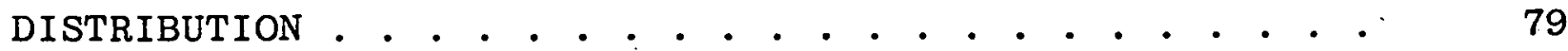




\section{ILLUSTRATIONS}

, Figure

Page

1

Definition of Burr Properties. . . . . . . .

Effect of Surface Velocity on Burr Height. . .

Effect of Workpiece Material on Burr Height. .

Effect of Drill Diameter on Burr Height. . .

Effect of Surface Velocity on Burr

Thickness. . . . . . . . . . . . . . . . .

Effect of Drill-Point Geometry on Burr Thickness. . . . . . . . . . . . .

Effect of Workpiece Material on Burr Thickness. . ...............

Effect of Helix Angle on Burr Radius . . . . . 21 Effect of Drill-Point Geometry on Burr Radius. . . . . . . . . . . . . . . .

Effect of Workpiece Material on Burr Radius . . . . . . . . . . . . . . .

Effect of Helix Angle and Drill-Point

Type on Burr Thickness . . . . . . . . . . .

Effect of Drill Diameter and Drill-Point

Type on Exit-Burr Height and Radius. . . . 
20 Desired and Actual Burr Conditions When Subland Drill Is Used. . . . . . . . . .

Subland-Drill Transition Angle to Minimize Counterbore Burr. . . . . . . .

Effect of Subland-Drill Feedrate on

Burr Thickness . . . . . . . . . . . .

Effect of Subland-Drill Spindle Speed on

Burr, Size. . . . . . . . . . . . . .

Effect of Workpiece Material on SublandDrill Burr Size. . . . . . . . . . . .

Effect of Number of Holes Drilled on Entrance-Burr Size Using Radial-Lip Drill in 6061-T6 Aluminum $\left(\mathrm{R}_{\mathrm{B}} 55\right)$. . . .

Effect of Number of Holes Drilled on Exit-Burr Height in 303Se Stainless Steel $\left(\mathrm{R}_{\mathrm{C} 33}\right) . . . . . . . . . .$.

Effect of Drill-Point Geometry on EntranceBurr Height (From Drill-Wear Study). . . .

Effect of Drill-Point Geometry on EntranceBurr Thickness (From Drill-Wear Study) . . .

Effect of Drill-Point Geometry on ExitBurr Height (From Drill-Wear Study). . . . .

Effect of Drill-Point Geometry on ExitBurr Thickness (From Drill-Wear Study)...

31 Test Sample With Consumable Backup Plug Used in Study of Cross-Hole-Burr Minimization . . . . . . . . . . . . . . . 
Deflection and Thickness of 1018 . Steel

Below Drill point as Drill Exits . ... . .

Deflection and Thickness of $17-4 \mathrm{PH}$

Stainless Steel (H900) Below Drill

Point as Drill Exits : . . . . . . . . . .

Material Deflection Below 0.125-Inch-

Diameter $(3.175 \mathrm{~mm})$ Drill Point in 303Se

Stainless Steel (Specimen 14; P-89226) . . .

Material Deflection Below Drill Point as

Drill Nears Breakthrough in 303 Se Stainless

Steel (Specimen 25; P-89209) . . . . . . .

Tearing of Material Below Drill Point in 17-4PH (H900) Stainless Steel (P-89214). . .

Short, Curled Drill-Exit Burr From 17-4PH (H900) Stainless Steel (P-76291) . . . . .

Cross Section of Long, Semiuniform DrillExit Burr From 6061-T6 Aluminum (P-92280). ,

Cross Section of Long, Semiuniform DrillExit Burr From 1018 Steel (P-92281). . . .

Ragged Drill-Exit Burr From 1018 Steel (P-87045). . . . . . . . . . . .

Cross Section of Ragged Drill-Exit Burr From 303Se Stainless Steel (P-92282) . . .

Cap of Metal Produced.From 1018 Steel (P-87046). . . . . . . . . . . .

Consecutive Burrs From 302 Stainless Steel (P-90328).................

Extruded Burr Formed by Dull Drill in Beryllium-Copper (P-88572) . . . . . . . 


\section{TABLES}

Number

Page

Drilling Conditions Used in the Study..... .

Analysis-of-Variance Summary of Significant Effects.

Average Measurements of Burr Properties. . .

Comparison of Burrs Produced by Subland Drills With Those Produced by Conventional Drills...................

Drilling Conditions Used in Subland-Drill Experiments. . . . . . . . . . . . . .

Analysis-of-Variance Summary of Significant Effects for Subland Drills . . . . . . .

Drilling Conditions Used in Drill-Wear

Study. • . . . • • . . . . . . . . . .

8 Effect of Drilling Variables on Entrance-

Burr Thickness . . . . . . . . . . . .

Effect of Drilling Variables on Entrance-

Burr Height. . . . . . . . . . . . . .

10 Effect of Drilling Variables on Exit-Burr Thickness. . . . . . . . . . . . .

11 Effect of Drilling Variables on Exit-Burr Height . . . . . . . . . . . . . . .

12. Recommended Variable Combinations to Minimize Exit-Burr Thickness... . . . . . . .

13 Recommended Variable Combinations to Minimize Exit-Burr Length .. . . . . . . . . . .

14 Surface Velocities and Feedrates Recommended for Radial-Lip Drills by the Manufacturer.

A-1 . Effects of Drill Geometry on Burr Size . . . . 
SUMMARY

Components of small precision mechanisms typically require nearly sharp, burr-free edges to assure their reliable operation. In the past, the removal of machining burrs with the assurance of part-edge sharpness have dictated that deburring be done only by hand. This method is inherently time-consuming and operatorvariable.

Small burrs are easily removed by many deburring processes. Because the repeatability of burr removal and the time required for removal are directly related to burr size, this study was initiated to determine the influence of drill geometry and drilling techniques upon the size of the burrs produced. The thickness and length of both entrance and exit burrs produced from 303Se stainless steel, 17-4PH stainless steel, 1018 steel, and 6061-T6 aluminum were measured: An explanation of the manner in which drilling burrs form also was developed.

Subland drills minimized the size of entrance burrs, but their use increased the tool cost by 600 percent. With two exceptions, little change was noted in burr properties as additional holes were drilled. However, increasing the feedrate from 0.001 to 0.003 ipr $(25.4$ to $76.2 \mu \mathrm{m} / \mathrm{rev})$ increased the thickness of both entrance and exit burrs by 40 percent. A similar increase in burr thickness and the radius on the backside of the burr occurred when the cutting velocity was increased from 50 to $100 \mathrm{sfpm}$ ( 255 to $510 \mathrm{~mm} / \mathrm{s}$ ).

The radial-lip and the four-facet-point drills produced equivalent results except when a large number of holes (exceeding 150) were drilled in 303 Se stainless steel. In the latter case, the radial-lip drill produced noticeably smaller burrs. In $303 \mathrm{Se}$ stainless steel, the material below the drill point was found to stretch by at least 10 percent before the drili broke through the
bottom surface.

Burr height was found to increase with increased drill diameter, but high helix angles of 37-1/2 degrees were found to reduce burr height by 50 percent and burr thickness by 20 percent.

While the use of a backup-rod was found to minimize the size of the burrs produced in cross-hole drilling, the burrs which formed on the rod tended to lock it in the hole, and they scratched the walls of the hole when the rod was removed.

The information obtained from this study will be combined with that obtained from similar tests of other machining operations to determine optimum machining conditions for minimizing the cost of deburring and other related fabrication expenses. 


\section{DISCUSSION}

\section{SCOPE AND PURPOSE}

This study was made to determine the manner in which conventional drilling practices influence the size of burrs. Specifically, it sought to determine how drill-point geometry, feedrate, workpiece material, workpiece thickness, and the use of backup material affect burr thickness and length.

\section{PRIOR WORK}

This report is the second in-depth study of drilling burrs by personnel of the Bendix Kansas City Division. In the first report, ${ }^{11}$ the effects of drill-point geometry, feedrate, and workpiece thickness were evaluated for four materials. Previous studies, less extensive, have also been reported at Bendix. ${ }^{2}, 3$

In related investigations, burrs produced by ballizing, reaming, end-milling, side-milling, and grinding have been described, 4-8 and general theories of burr formation have been developed. Some experimental work has been reported by other agencies on drilling burrs, $12-19$ stamping burrs, $20-26$ and burrs formed from electrical-discharge machining. ${ }^{2}$

\section{ACTIVITY}

All conventional machining operations produce some burrs, the size of which depend upon the tool-geometries used, the speeds and feedrates, and the properties of the workpiece material. The cost of removing the burrs is proportional to the burr size. When miniature precision parts are involved, the close tolerances, minute part size, and large burr size often may cause the burrremoval cost to approach the cost of machining the parts.

To minimize these fabrication costs, the manner in which deburring costs vary with burr size and the influence of machining conditions upon burr size must be analyzed. A series of tests therefore have been initiated to provide data on burr properties as a function of machining conditions. The complete series of tests will include most of the common machining operations.

This study consists of five sets of tests. In the first set, two drill-point geometries were evaluated in four materials for two drill diameters at two surface velocities. In the second set of tests, subland drills were used to determine whether a light counterboring action would eliminate noticeable burrs on the 
entrance-side of the holes. The third set consisted of a drill-life evaluation of three drill-point geometries in three workpiece materials. The use of removable, consumable backup material for cross-hole drilling was evaluated in the fourth set of tests. Material deflection below the drill point was studied in the fifth set.

Effects of Helix Angle, Diameter, Velocity, Point Geometry, and Workpiece Material

The initial tests in this study were designed to determine the manner in which drill helix angle, diameter, point geometry, and surface velocity affected the burr size for four workpiece materials. However, because of repeated cases of drill breakage in 17-4PH (H900) stainless steel, results for only the following three materials are described: 303 Se stainless steel $\left(R_{C} 34\right)$; 1018 steel $\left(R_{B} 99\right)$; and 6061-T6 aluminum ( $\left.R_{B} 54\right)$. Except for aluminum, the specimens consisted of 0.127 -inch-thick ( $3.175 \mathrm{~mm}$ ) discs, each 0.500 inch $(12.7 \mathrm{~mm})$ in diameter. The thickness of the aluminum specimens was 0.188 inch. $(4.78 \mathrm{~mm})$. Drilling was performed on a Hardinge HLV lathe using power feed and a flood coolant. Five specimens were machined at each of the 48 conditions evaluated.

The test conditions used in this study are indicated in Table 1. All radial-lip drills were ground by the Radial Lip Machine Company (Lake Bluff, Illinois).

The four-facet drills were off-the-shelf, screw-machine-length, high-speed-steel drills (List Numbers 957 and 967 , Cleveland Twist Drill, Cleveland, Ohio) with a 128-degree, printed-circuitboard four-facet point added. The feedrate was maintained constant at 0.001 ipr $(25.4 \mu \mathrm{m} / \mathrm{rev})$. The height, thickness, and radius on the back surface of each burr were measured at both the drill-entrance and drill-exit sides of each hole (Figure 1). The data obtained are shown in Table A-1 of the Appendix.

An analysis-of-variance (ANOVA) indicated that each of the factors studied affected at least two of the six properties measured (Table 2). However, considering only the exit burr, which is much larger than the entrance burr, only the belix angle and the drill diameter played major roles in determining the burr properties. As indicated by the large number of interactions, there are unique combinations of variables which show significantly different results than would have been predicted from the
averaged data. 
Table 1. Drilling Conditions Used in the Study

Leve1

\begin{tabular}{|c|c|c|c|}
\hline \multirow{2}{*}{ Condition } & & & \\
\hline & 1 & 2 & 3 \\
\hline A Helix Angle & $\begin{array}{l}\mathrm{High}-- \\
\left(37-1 / 2^{\circ}\right)\end{array}$ & $\begin{array}{l}\text { Norma 1-- } \\
\left(27-1 / 2^{\circ}\right)\end{array}$ & \\
\hline $\begin{array}{l}\text { B Drill Diameter } \\
\text { (Inch)* }\end{array}$ & 0.250 & 0.125 & \\
\hline $\begin{array}{l}\text { C Surface Velocity } \\
\text { (SFPM)** }\end{array}$ & 100 & 50 & \\
\hline D Drill-Point Type & Radial Lip & Four-Facet & \\
\hline E Material & 1018 Steel & $303 \mathrm{Se}$ SST & 6061-T6 AI \\
\hline
\end{tabular}

Burr Height

Although the entrance-burr height decreased slightly with increased cutting velocity (Figure 2), the exit-burr height was unaffected by the cutting velocity. (Unless otherwise indicated, the results shown are averages for the three different materials used in the study.) Entrance burrs were on $1 \mathrm{y} 0.0014$ inch $(35.6 \mu \mathrm{m})$ high, while typical exit burrs were 0.0056 inch $(142.2 \mu \mathrm{m}) \mathrm{high}$ (Table 3). Exit burrs from 303Se stainless steel were slightly higher than those from 1018 steel (Figure 3 ). High helix angles reduced noticeably the height of both entrance and exit burrs (Figure 4). The exit-burr height was directly proportional to the drill diameter (Figure 5). Results from the radial-lip drill were similar to those from the conventional drill (Table 2).

Burr Thickness

The 37-1/2-degree helix angle resulted in noticeably thinner burrs, than were produced by the standard 27-1/2-degree helix angle (Figure 6 ). Increasing the surface velocity increased the burr thickness (Figure 7). The exit burrs tended to be 30 percent thicker than the entrance burrs (Figures 6, 7, and Table 3). The radial-lip drill point did not produce thinner burrs than did the four-facet point (Figure 8). In this study, the thinnest burrs occurred from 303Se stainless steel (Figure 9), although the difference was not great. 


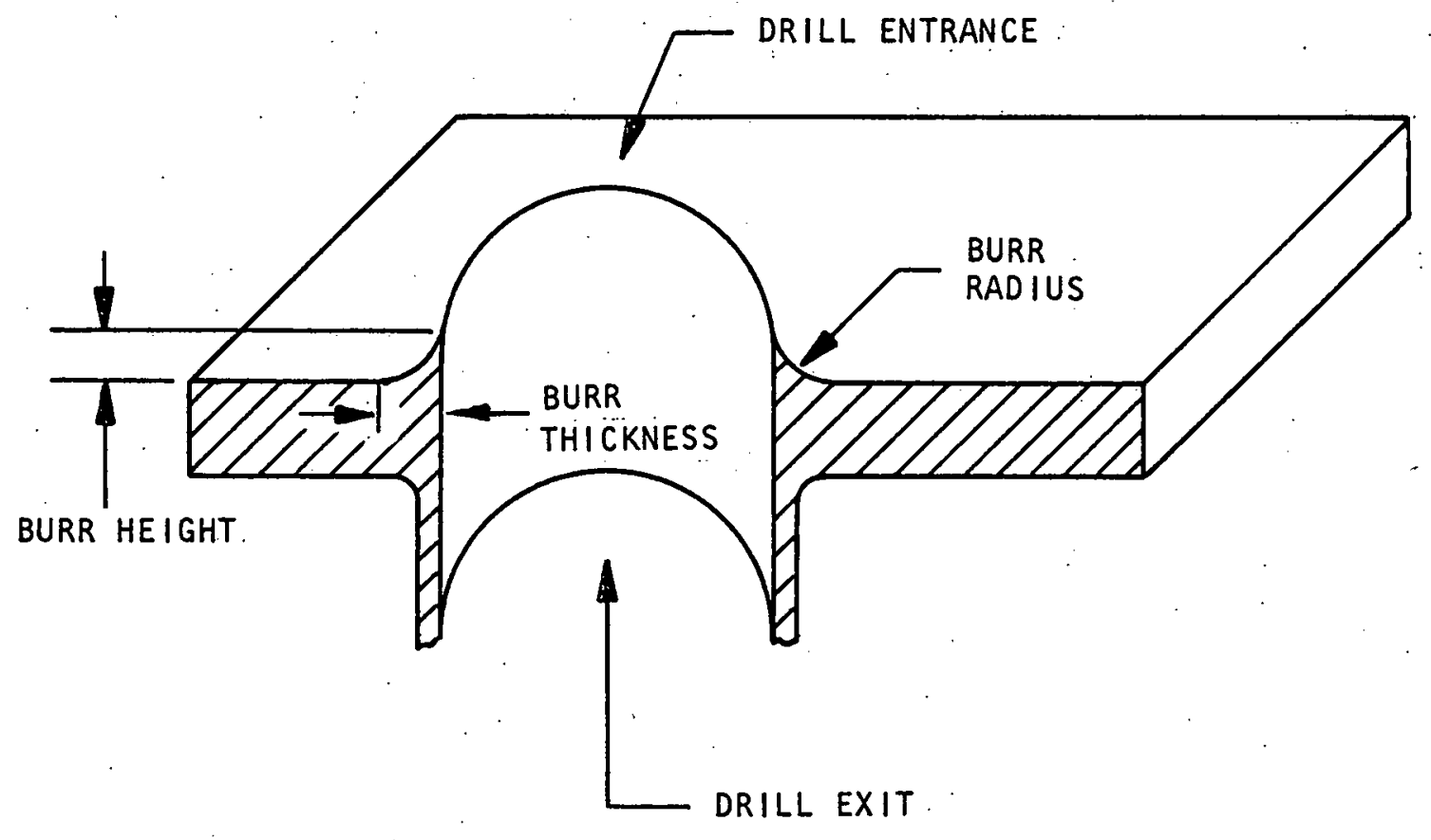

Figure 1. Definition of Burr Properties

Burr Radius

The burr radius decreased with an increase in the helix angle (Figure 10). The exit-burr radius increased slightly with an increase in the drill diameter (Figure 11). Increasing the cutting velocity also increased the burr radius (Figure 12). The radial-1ip drill produced a larger entrance-burr radius than did the four-facet point (Figure 13). The smaller radii occurred in burrs from 303Se stainless steel, and the larger in burrs from 6061-T6 aluminum (Figure 14).

Effects of Specific Variable Combinations

As shown in Figure 15, the conventional helix angle on a 0.25 -inch $(6.35 \mathrm{~mm})$ drill resulted in much higher burrs than did the other combinations. The high helix angle combined with the four-facet drill point produced thinner burrs than, the other combinations (Figure 16). The exit-burr height and radius were the least when the small-diameter four-facet drill points were used (Figure 17). The burr height from the aluminum specimen was not as velocity-dependent as it was from the other materials (Figure 18). 
Table'2: Analysis-Of-Variance Summary of Significant Effects

\begin{tabular}{|c|c|c|c|c|c|c|}
\hline \multirow[b]{3}{*}{ Conditions* } & \multicolumn{6}{|c|}{ Significant Effects } \\
\hline & \multicolumn{3}{|c|}{ Entrance Burr } & \multicolumn{3}{|c|}{ Exit Burr } \\
\hline & $\begin{array}{l}\text { Thick- } \\
\text { ness }\end{array}$ & Length & Radius & $\begin{array}{l}\text { Thick- } \\
\text { ness. }\end{array}$ & Leng:th & Radius \\
\hline A & $* * *$ & $* * *$ & & $* *$ & $* * * *$ & $* * * *$ \\
\hline B & & & & & $* * *$ & $* * *$ \\
\hline $\mathrm{C}$ & $* * * *$ & $* * *$ & $* *$ & $* *$ & & \\
\hline D & $* *$ & & $* *$ & & & \\
\hline $\mathbf{E}$ & $* * *$ & $* * *$ & $* *$ & & & \\
\hline $\mathrm{AB}$ & & & & & $* * *$ & $* * *$ \\
\hline $\mathrm{AC}$ & $* * * *$ & $* * *$ & $* * *$ & & & \\
\hline $\mathrm{AD}$ & $* *$ & & & $* *$ & & \\
\hline $\mathrm{AE}$ & $* *$ & $* *$ & & & & \\
\hline $\mathrm{BC}$ & & & & & & \\
\hline $\mathrm{BD}$ & & & & & $* *$ & $* *$ \\
\hline $\mathrm{BE}$ & & & & & & \\
\hline CD & & & $\cdot$ & & & \\
\hline $\mathrm{CE}$ & $* *$ & $* * *$ & & $* *$ & $* *$ & $* *$ \\
\hline $\mathrm{DE}$ & $* *$ & $* * *$ & $* *$ & & - & . \\
\hline $\mathrm{ABC}$ & $* * *$ & & $* *$ & & & \\
\hline $\mathrm{ABD}$ & & & & $* *$ & $* *$ & $* *$ \\
\hline $\mathrm{ABE}$ & $* *$ & & & & & \\
\hline
\end{tabular}


Tabie 2 Continued. Analysis-Of-Variance Summary of Significant Effects

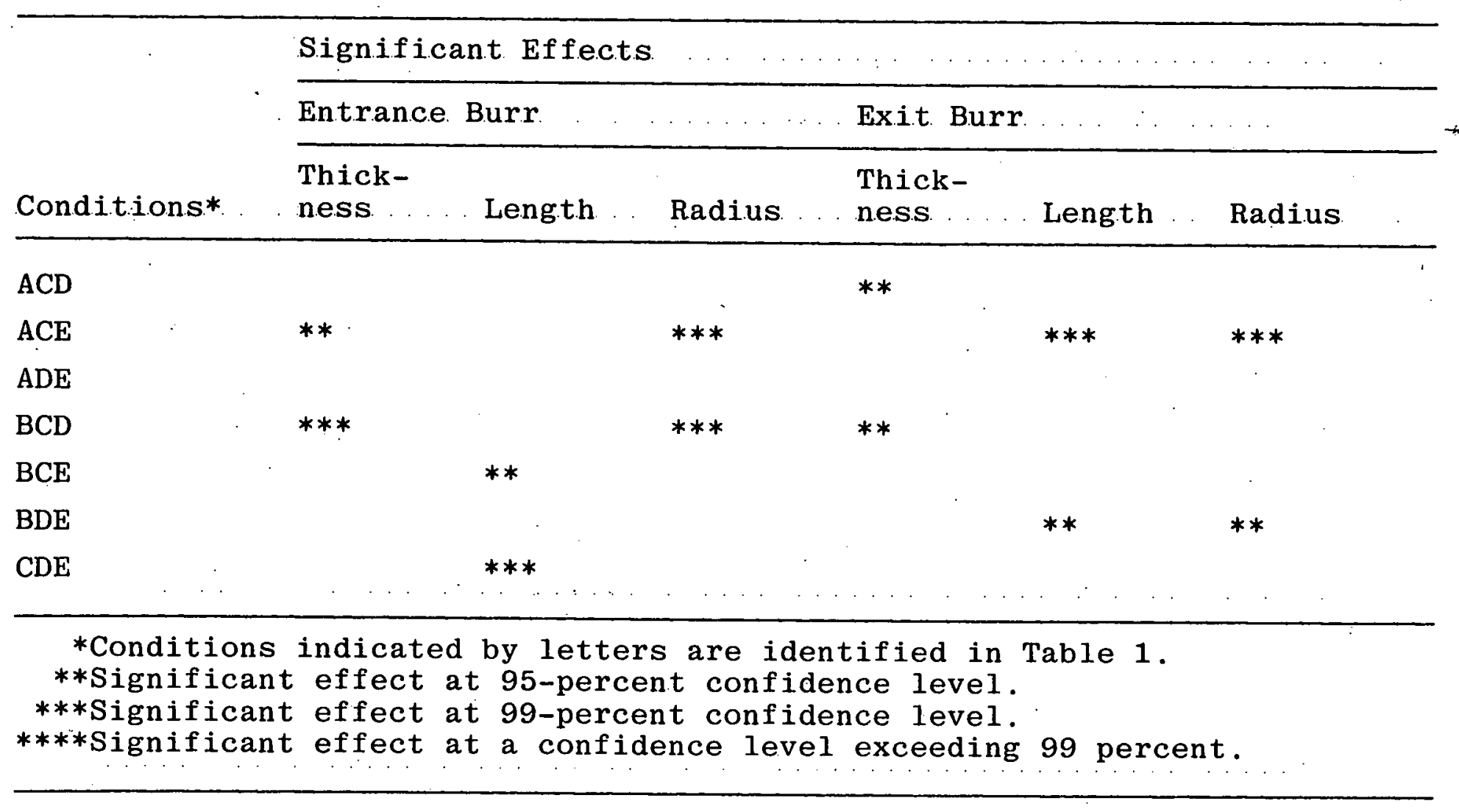




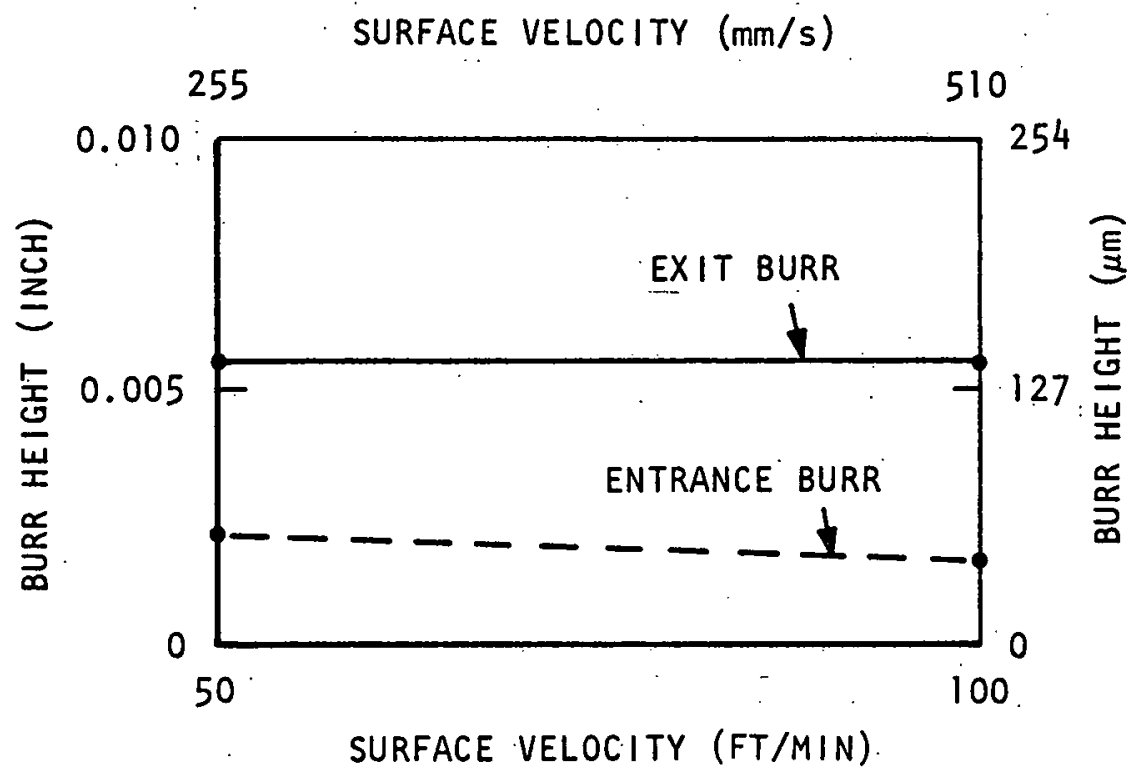

Figure 2. Effect of Surface Velocity on Burr Height

Effects of Feedrate, Spindle Speed, and Workpiece Material With Subland Drilis

In the second study, subland drills (List Number 1401, Mohawk Tools Inc., Montpelier, Ohio) were used to determine whether the transitional area from the small to the large diameter of the drill would provide the hole with a burr-free entrance-side. Ideally, the transitional area should remove any burr which is formed when the small diameter of the drill enters the workpiece. In essence, this type of tool can be an integral drilling-deburring tool; however, it does not affect the burr on the exit-side of the hole.

When in operation, the subland drill is lowered until the transitional area just touches the entrance-surface of the workpiece. In practice, a very shallow counterbore must be produced to assure the removal of the entrance burr (Figures 19 and 20). Although a second burr is produced at the diameter of the counterbore, it is very small and. easy to remove.

As shown in Table 4 , the subland drill minimized the entrance-burr size for all materials, although the burr produced at the counterbore was approximately the same size as the original entrance burr. The counterbore burr probably could be virtually eliminated by utilizing a transition angle that is slightly greater than 90 degrees; this tool then would not produce a distinct edge if it were stopped before the large cutting diameter entered the 
Table 3. Average Measurements of Burr Properties

\begin{tabular}{lll}
\hline Burr Property* & $\begin{array}{l}\text { Entrance } \\
\text { Burr }\end{array}$ & $\begin{array}{l}\text { Exit } \\
\text { Burr }\end{array}$ \\
\hline Height (Inch)** & 0.0014 & 0.0056 \\
Thickness (Inch) & 0.0023 & 0.0030 \\
Radius (Inch) & 0.0019 & 0.0021 \\
\hline $\begin{array}{l}\text { *Values were obtained from the average } \\
\text { Of four materials. }\end{array}$ & \\
**0.0001 inch $=2.54$ & $\mu \mathrm{m}$. \\
\hline
\end{tabular}

workpiece (Figure 21). The point geometry of the subland drill produced significantly larger exit burrs than did the four-facet point. This also could be prevented by grinding a four-facet point on the subland drill.

In addition to determining the effect of the subland-drill design upon burrs, the effects of feedrate, spindle speed, and workpiece material also were evaluated. The machining variables studied are shown in Table 5; the data obtained are shown in Table A-2 of the Appendix. The analysis-of-variance is presented in Table 6. As indicated, no factor affected all properties. The thickness of both the entrance and exit burrs was affected by each of the three variables studied. The most noticeable trends are shown in Figures 22 through 24. As indicated in Figures 22 and 23 , the burr thickness increased as the feedrate and spindle speed were increased. The entrance-burr length also increased slightly as the spindle speed was increased. Typically, burrs from 303 Se stainless steel were thicker than those from the other materials (Figure 24).

\section{Effect of Drill Wear}

The third test under this project investigated the effect of drill wear on the properties of the burrs. The materials and the 0.125 -inch-diameter $(3.175 \mathrm{~mm})$ drills used in the previous tests were used in this test. Eight-facet drills also were used, in addition to the other 0.125-inch-diameter drills. (Eight-facét drills are four-facet drills with another chamfer added at the drill corners. ${ }^{1}$ )

Text continued on page 23 . 


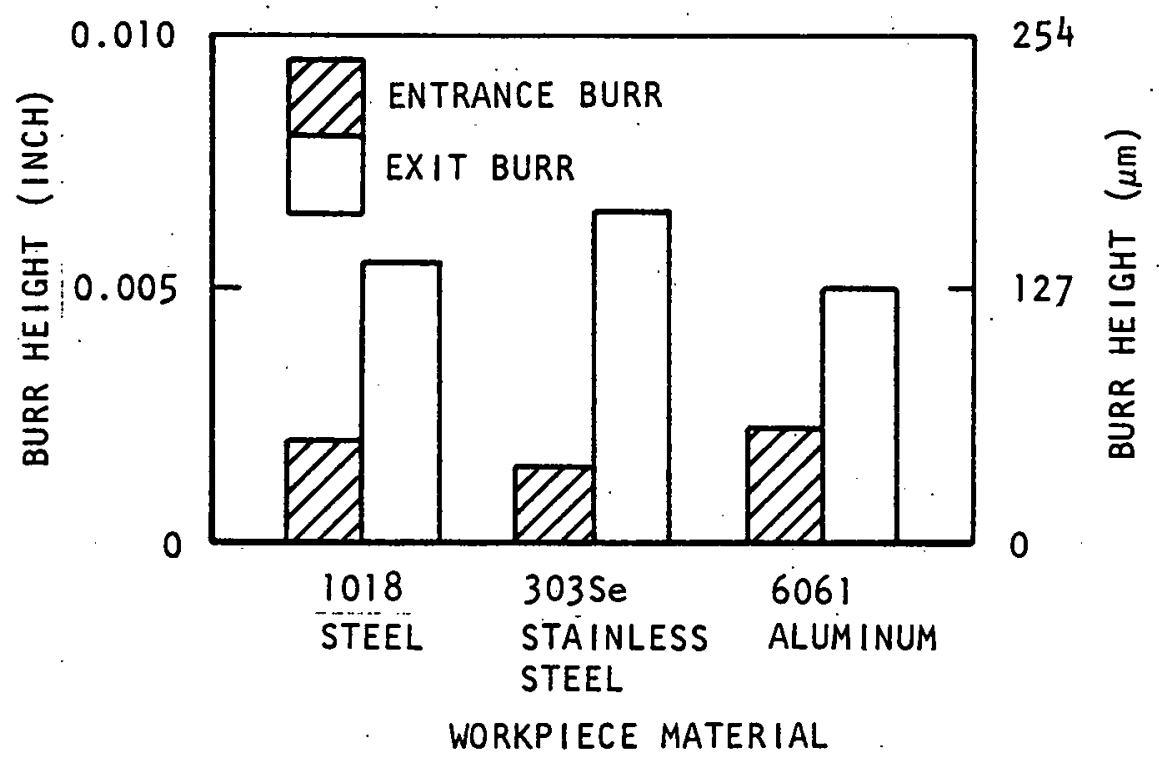

Figure 3. Effect of Workpiece Material on Burr Height

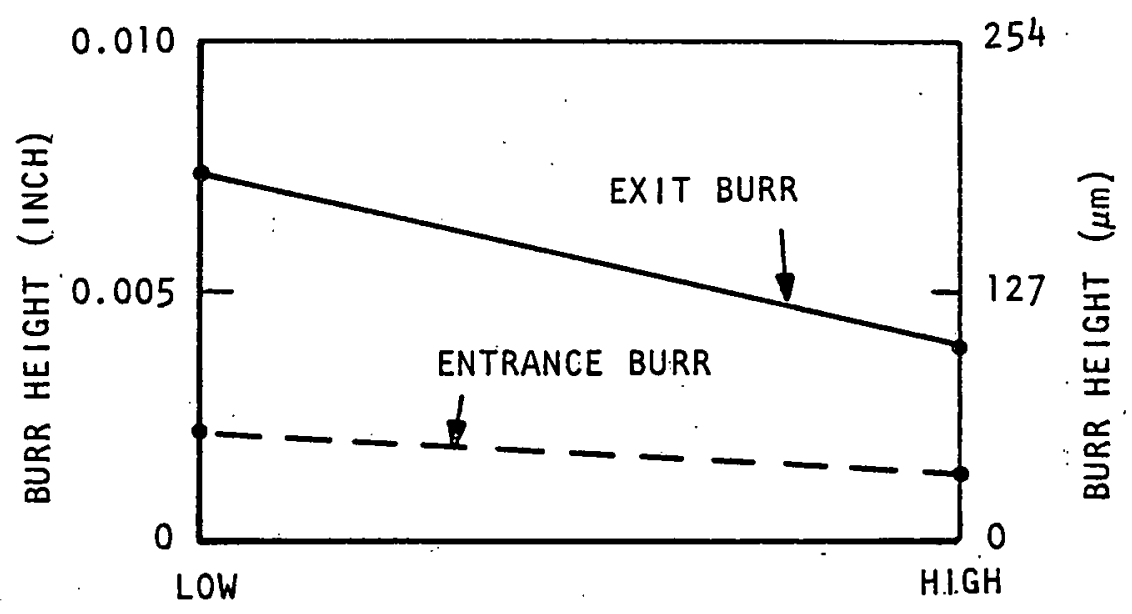

HELIX ANGLE

Figure 4. Effect of Helix Angle on Burr Height 
DRILL DIAMETER (mm)

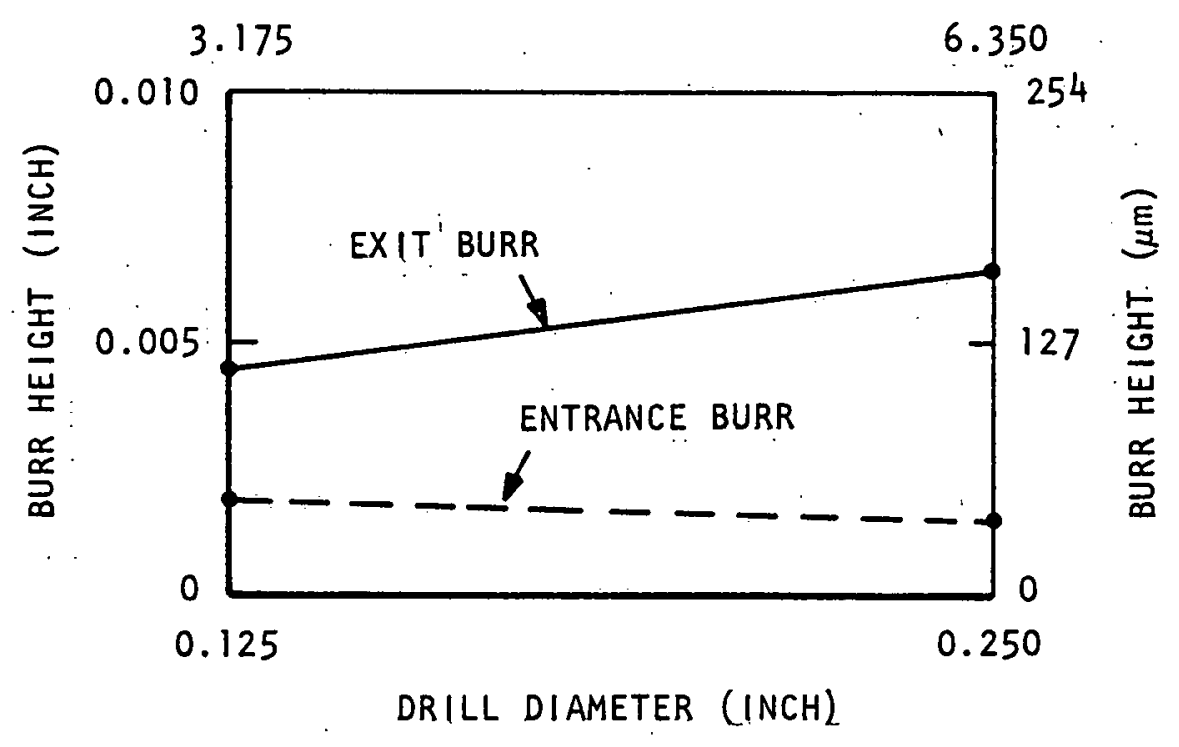

Figure 5. Effect of Drill Diameter on Burr Height

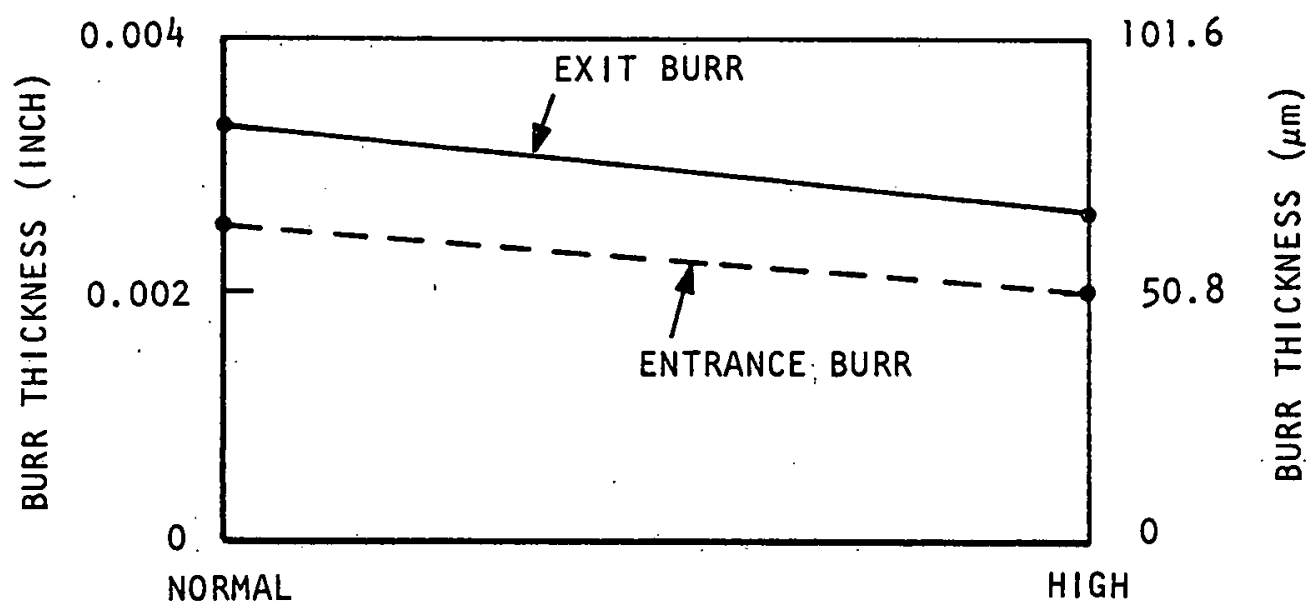

HELIX ANGLE

Figure 6. Effect of Helix Angle on Burr Thickness 


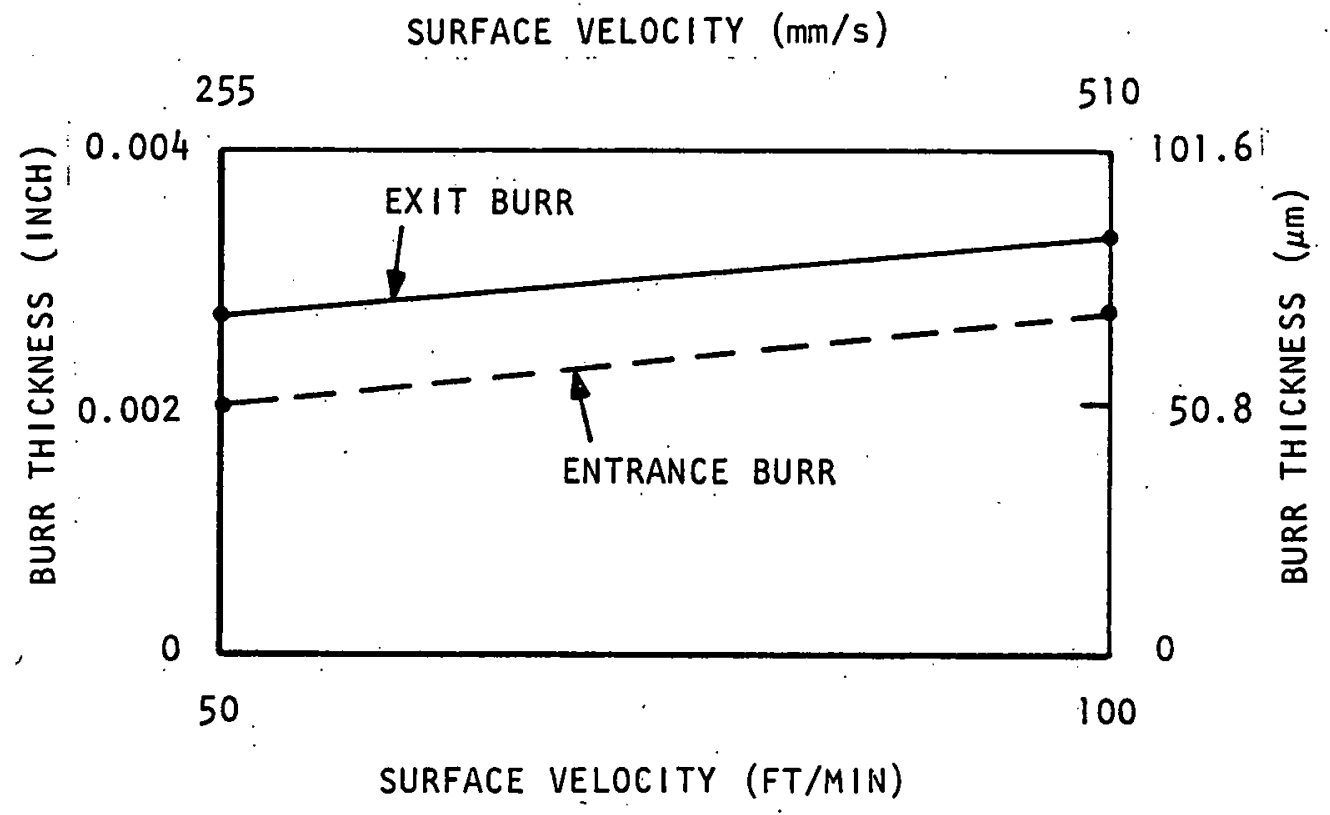

Figure 7. Effect of Surface Velocity on Burr Thickness

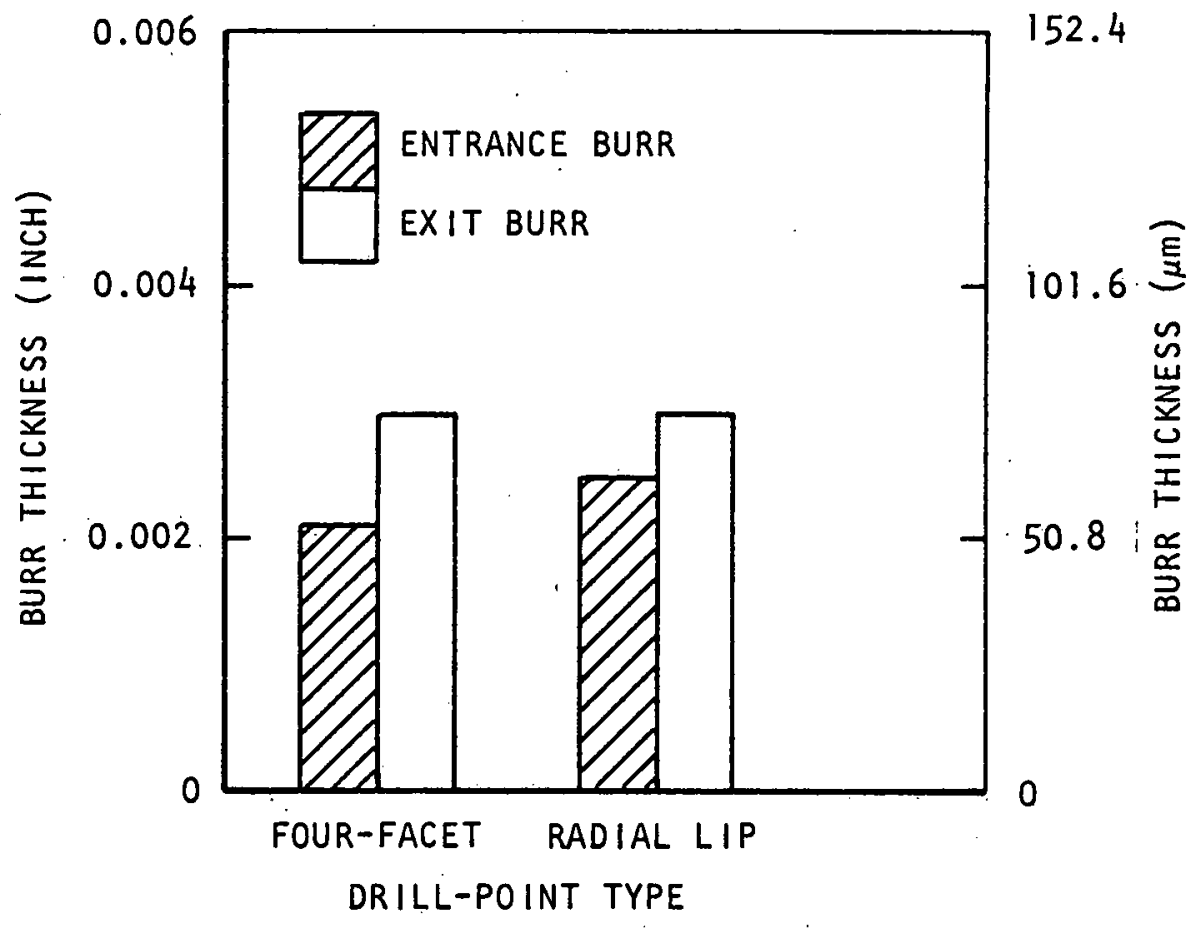

Figure 8. Effect of Drill-Point Geometry on Burr Thickness 


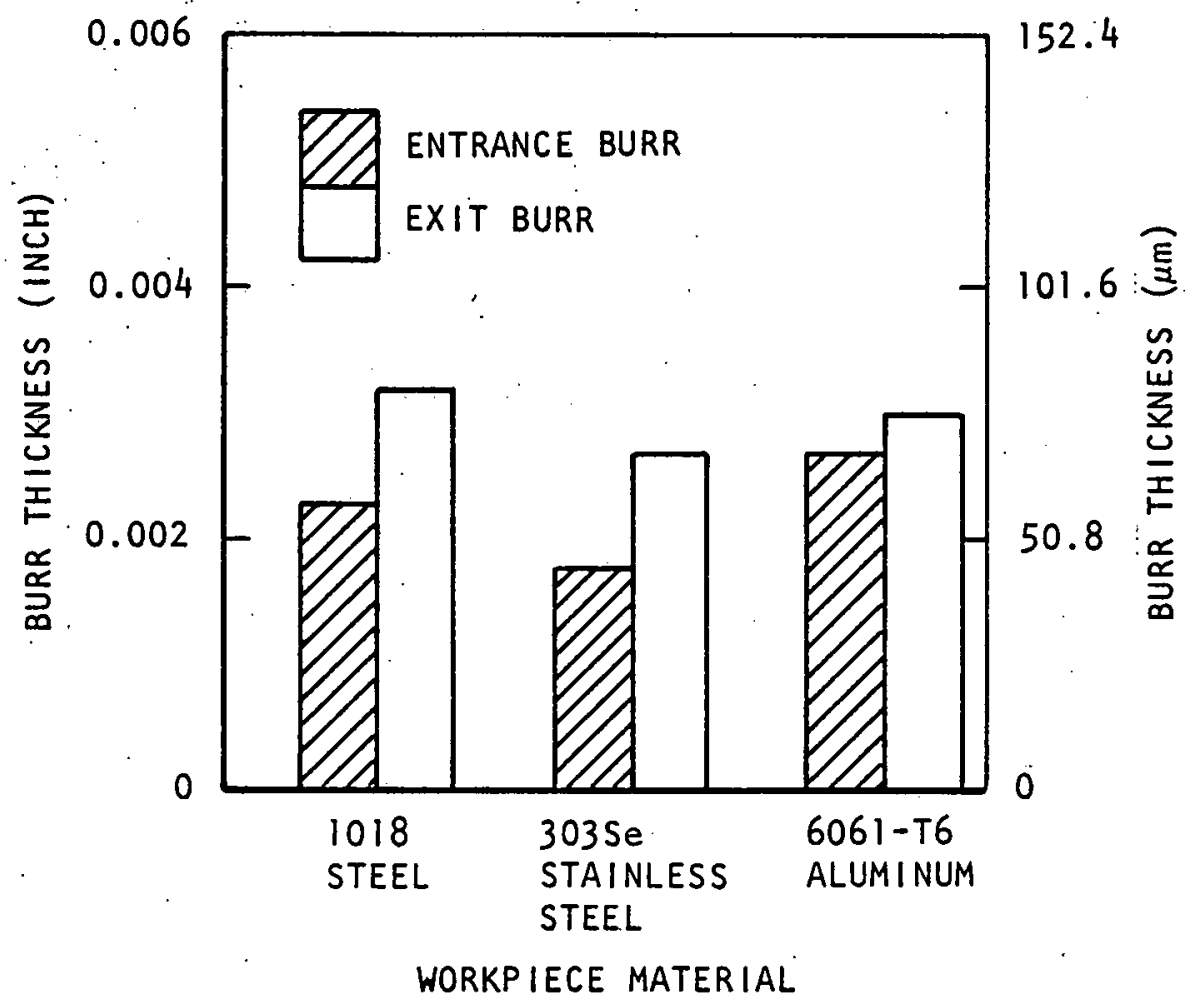

Figure 9. Effect of Workpiece Material on Burr Thickness

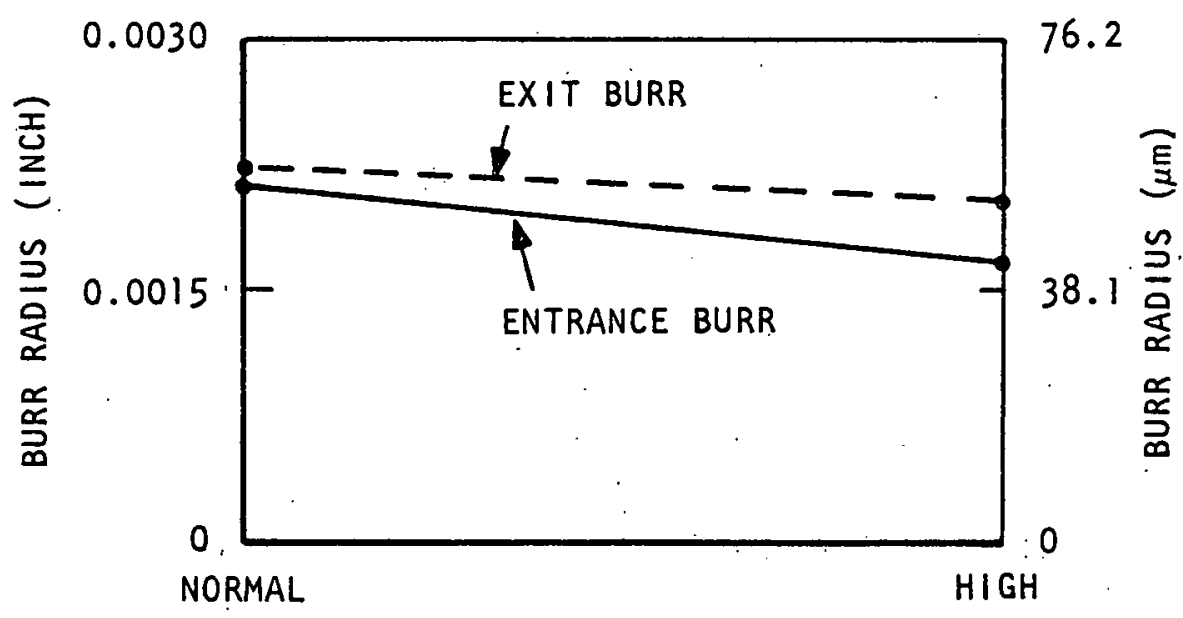

HELIX ANGLE

Figure 10. Effect of Helix Angle on Burr Radius 


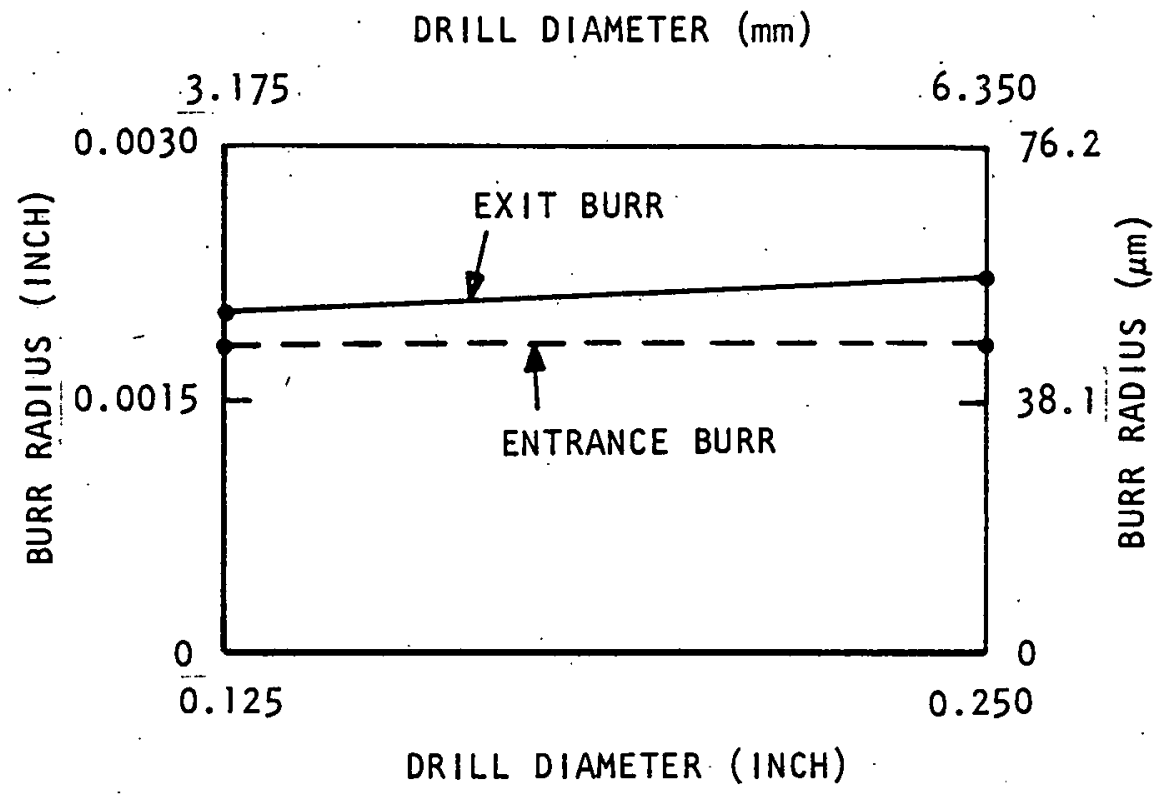

Figure 11. Effect of Drill Diameter on Burr Radius

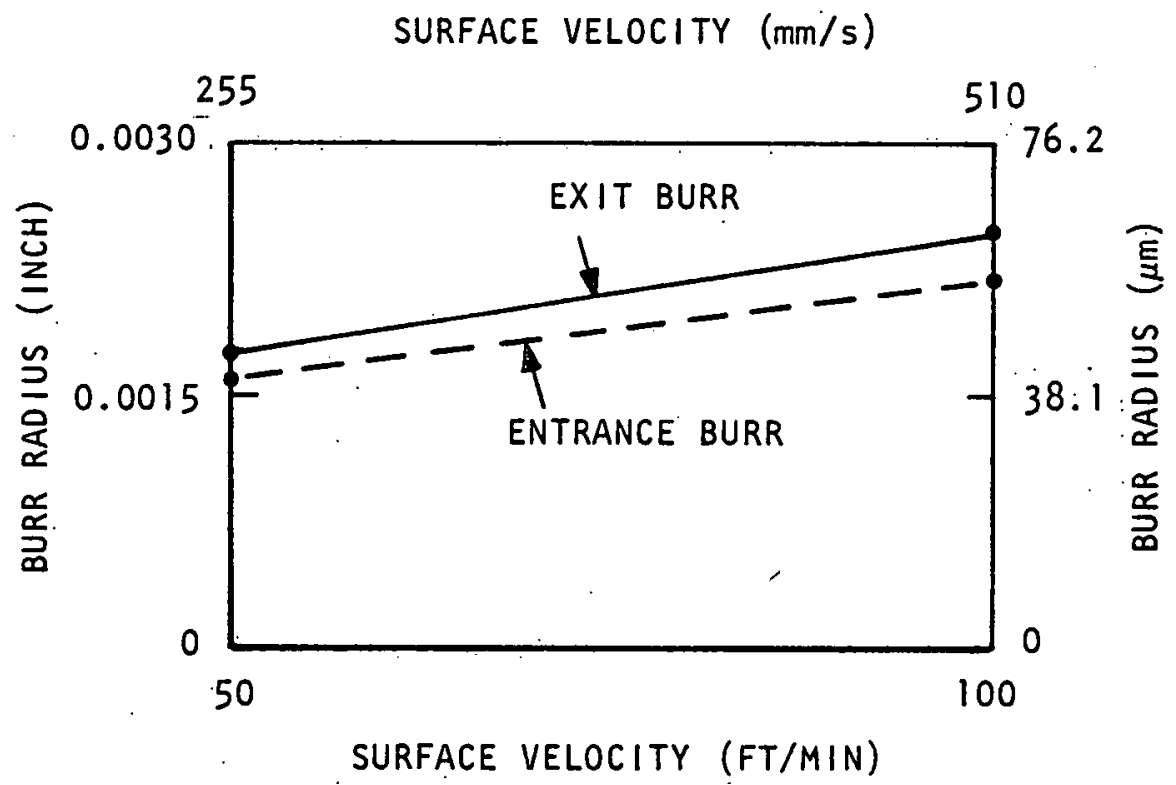

Figure 12. Effect of Surface Velocity on Burr Radius 


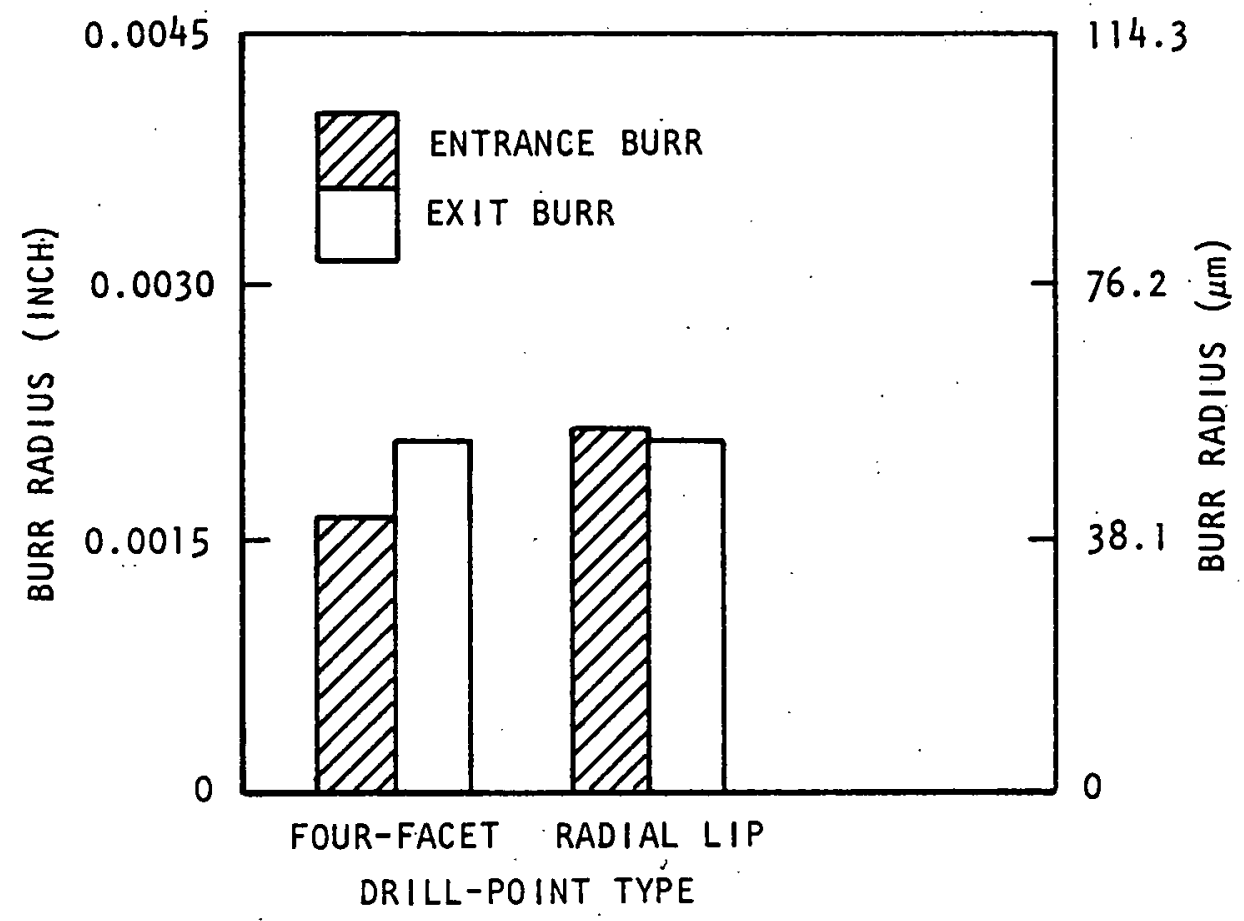

Figure 13. Effect of Drill-Point Geometry on Burr Radius

To duplicate typical production practice, the speeds were varied with each material. Table 7 indicates the drilling conditions that were used. The holes were drilled with an N/C machining center, using a water-soluble flood coolant. All were through holes in a 1/4-inch-thick $(6.35 \mathrm{~mm})$ bar which had been ground to eliminate mill scale and surface residues. No backup material was used to minimize the burr size.

Both the entrance and exit burrs were measured from metallurgical mounts. Four readings were taken of each burr; the data obtained are shown in Table A-3 of the Appendix. Prior to measuring the length, the loose burr fragments were removed by wiping a hand over them. Thus the burr lengths shown represent only the burrs which would be significant in deburring efforts.

Only one of the drill-workpiece combinations studied exhibited any noticeable wear tendency: the entrance-burr height increased with the number of holes drilled when the radial-lip drill was used, but the entrance-burr thickness decreased as the number of holes increased for the same drilling combination (Figure 25-Data are shown in Table A-3 of the Appendix; data for the first 46 holes have been previously published ${ }^{1}$ ). 


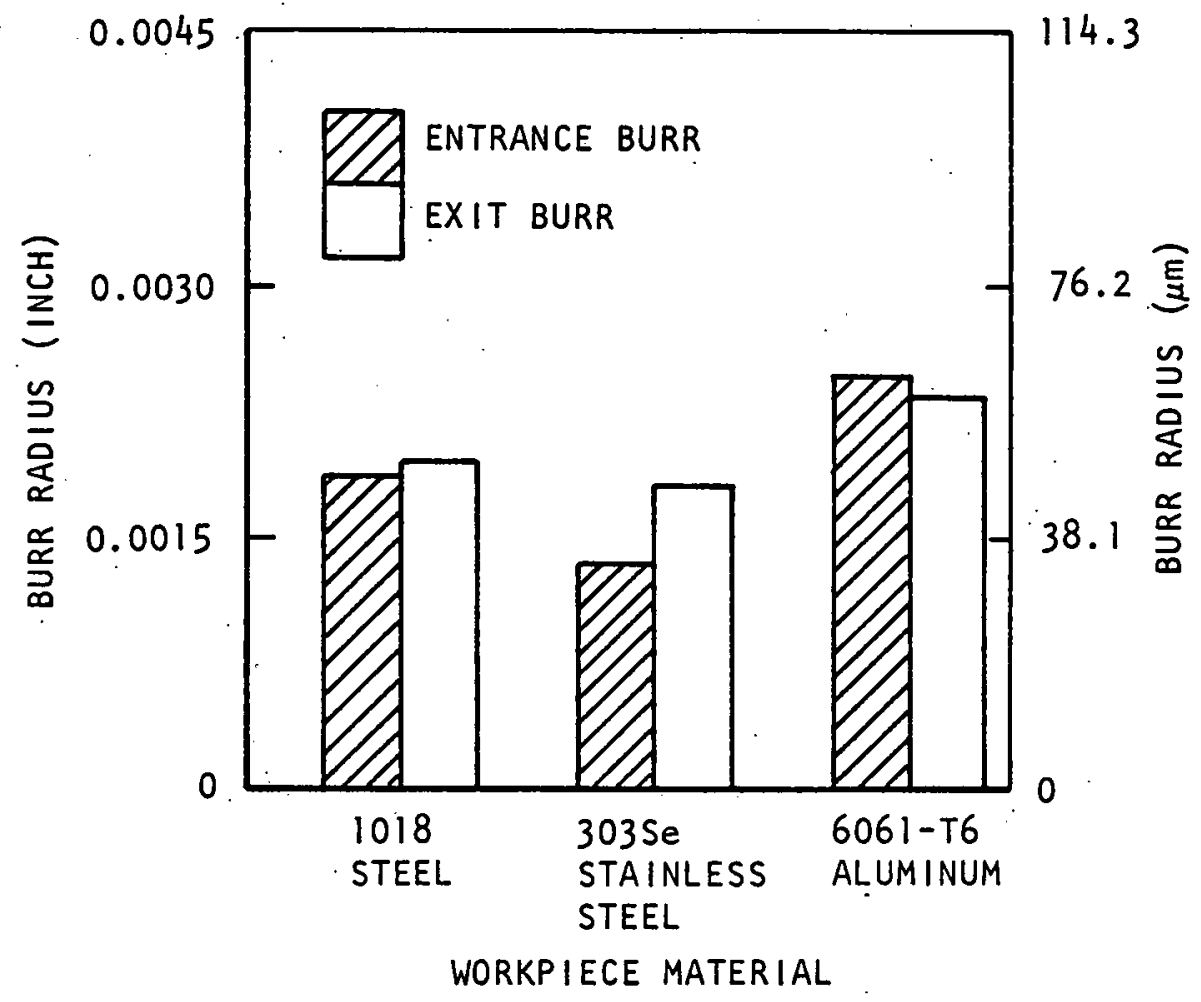

Figure 14. Effect of Workpiece Material on Burr Radius

Except for the burrs produced by the four-facet drill from 303Se stainless steel, no changes in the exit burrs were evident (Figure 26). The four-facet drill appeared to wear rapidly after 125 holes; however, the data were insufficient to determine whether this was a real trend.

Because significant trends were not apparent, except for the combinations just described, the means and standard deviations (o) were calculated to provide comparative data. For these calculations, the data used were from Holes 51 through 184. As shown in Figures 27 through 30 , the radial-lip drill produced significantly smaller burrs than did the four-facet drill in 303Se stainless steel. Little or no difference was observed in burrs from the other two materials. The burrs produced by this drill in $303 \mathrm{Se}$ stainless steel were more uniform (had a small standard deviation) than those produced by the four-facet drill. 


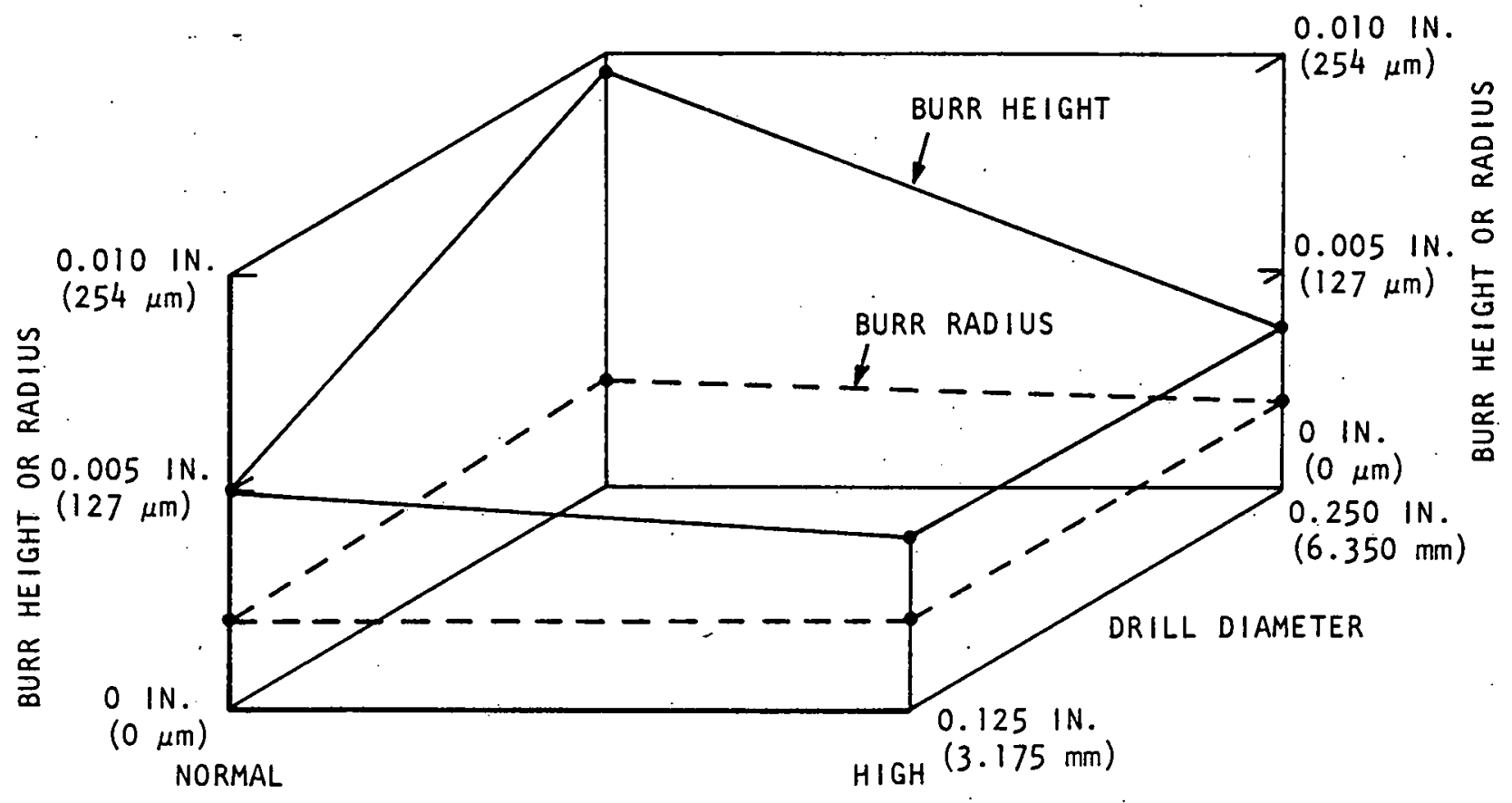

HEL IX ANGLE

Figure 15. Effect of Helix Angle and Drill Diameter on Exit-Burr Height and Radius

Burr Minimization in Cross-Hole Drilling

In the fourth study, an attempt was made to minimize the size of burrs which form when the drill breaks through into another drilled hole. In this test, the first hole drilled in the workpiece was plugged with a removable rod (Figure 31). Both the workpiece and the rod were of 303 Se stainless steel. The rod served as sacrificial backup material to minimize the formation of a large burr.

The use of the consumable rod resulted in shorter burrs being produced at the intersection of the holes; obviously, the long, ragged portion of the burrs could not form. Because the intersection of the holes is a three-dimensional surface, accurate measurements of the differences in burr thickness were impossible to obtain; however, under a magnification of $80 \mathrm{X}$, the burrs produced with the backup-rod in place appeared to be thinner than those produced without the rod by 50 percent.

When the cross-hole was the same diameter as the initial hole, improvement in the burr size occurred without use of the backup-rod because the drill diameter just touched the sides of the first drilled, hole at two places (Figure 32). At these points there was no open area for a burr to form; a burr did form, however, on the remaining portions of the hole intersection. 


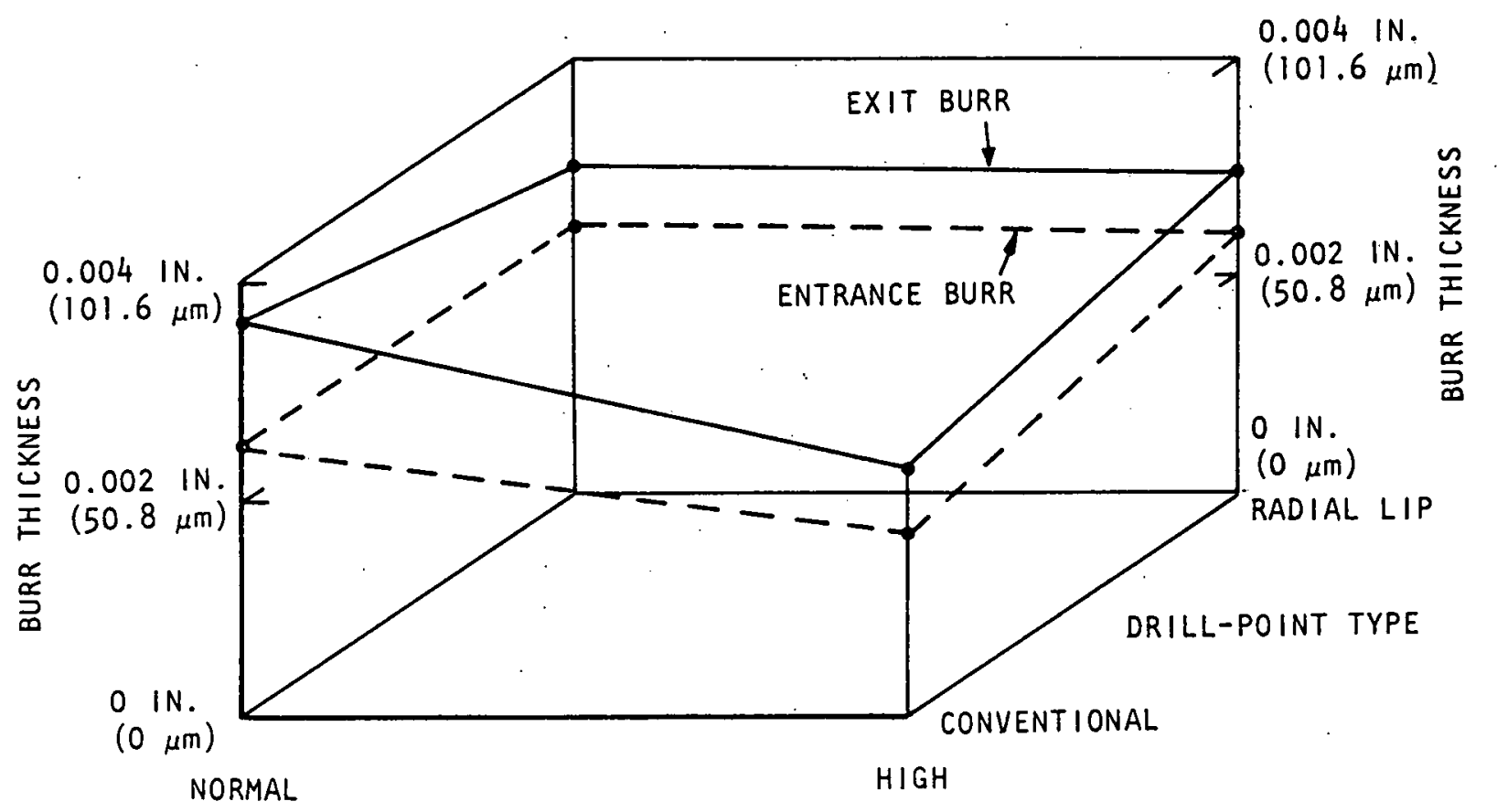

HELIX ANGLE

Figure 16. Effect of Helix Angle and Drill-Point Type on Burr Thickness

The following observations were recorded from this study. When the cross-hole is close to the same size as the first hole drilled, the backup-rod, if used, will be cut in half. Because the slight burr which forms is sufficient to hold both halves of the rod in the workpiece, the rod cannot be used when the first hole is blind since there is no way of removing the bottom portion of the rod from the part. If the rod used is longer than the depth of the hole, the top portion can be removed. In the case of through holes, of course, both pieces of the rod can be knocked out of the part.

In applications where the bottom of the hole-intersection need not be clear, the captured portion of the rod can remain in the hole. However, since the remaining portion of the rod might rotate, and since the drilled portion of the rod does not have a flat surface, a projection may result to block any flow or motion through the cross-hole.

Despite a noticeable change in the burr properties of parts having cross-hole intersections, only a slight saving occurs in the deburring cost when the parts are deburred manually. Deburring of the hole intersections so that 0.005 -inch-maximum (127 $\mu \mathrm{m}$ ) edge breaks were maintained required 12 minutes per part when the backup-rod was used, and 10 minutes per part when it was not used. 
$0.010 \mathrm{IN}$.

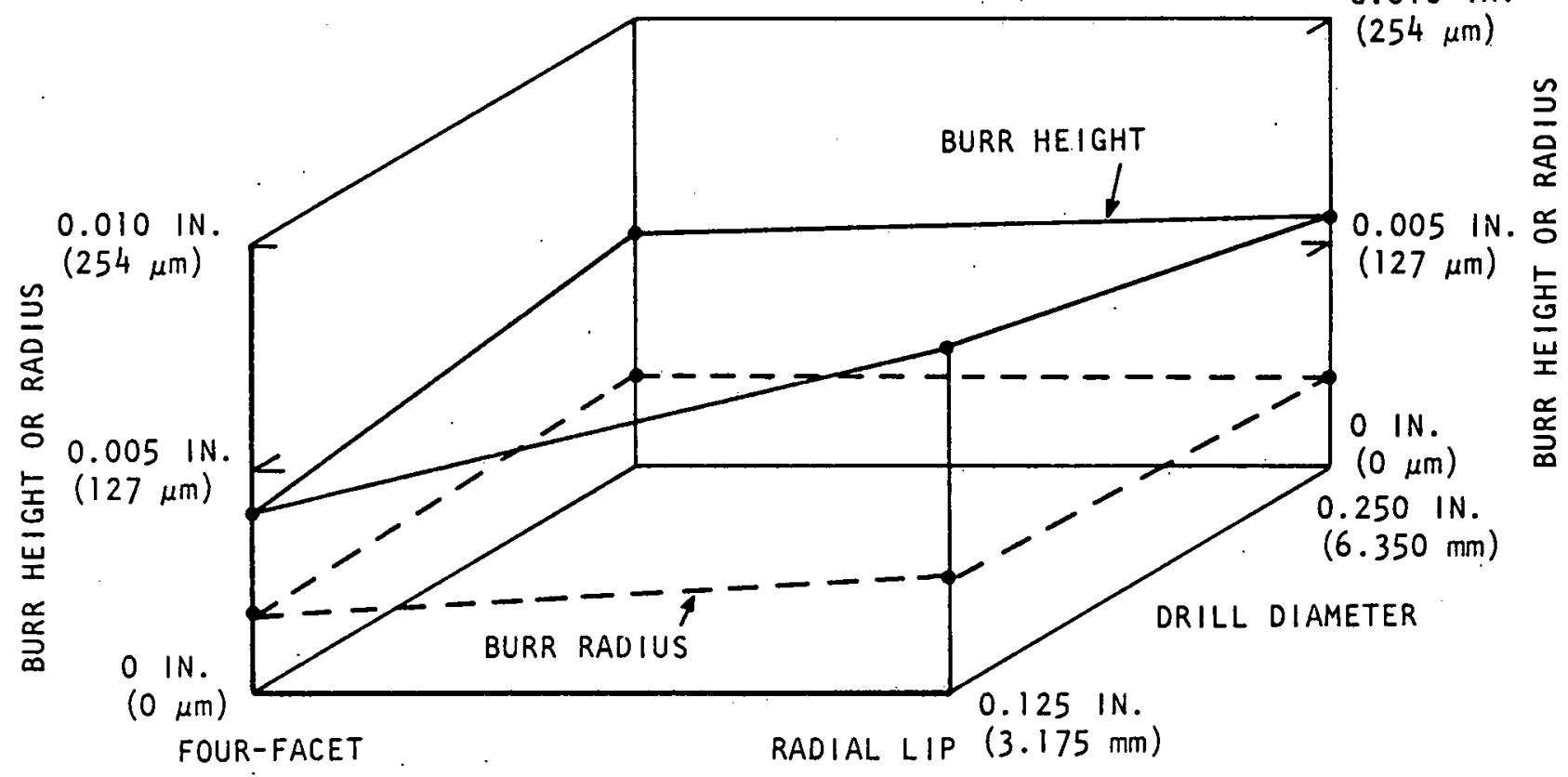

DRILL-POINT TYPE

Figure 17. Effect of Drill Diameter and Drill-Point Type on Exit-Burr Height and Radius

The use of the backup-rod would have a more significant effect if electrochemical or extrude hone deburring were used, since both of these processes are sensitive to long, flexible burrs. In the first process, the long burrs increase the chance of electrical short circuits and consequent part damage. In the second process, the long burrs fold over flush with the hole walls and thus slow the deburring operation.

The Formation of Burrs at Drill-Breakthrough

The formation of drill-exit burrs was briefly studied by crosssectioning workpiece samples as the drill began to exit from the bottom of the workpiece. The workpiece materials studied included $303 \mathrm{Se}$ and $17-4 \mathrm{PH}$ stainless steel, 1018 steel, and 6061-T6 aluminum in the disc form used in the first test previously described. A high-speed-steel drill, 0.125 inch ( $3.175 \mathrm{~mm}$ ) in diameter (List Number 967, Cleveland Twist Drill Co., Cleveland, Ohio), was used at a speed of $1200 \mathrm{rpm}$ and a feedrate of $03.6 \mathrm{ipm}$ $(1.53 \mathrm{~mm} / \mathrm{s})$ in all materials except the 17-4PH stainless steel. For the latter material, a speed of $750 \mathrm{rpm}$ and a feed of $1.2 \mathrm{ipm}$ $(0.51 \mathrm{~mm} / \mathrm{s})$ were used. 


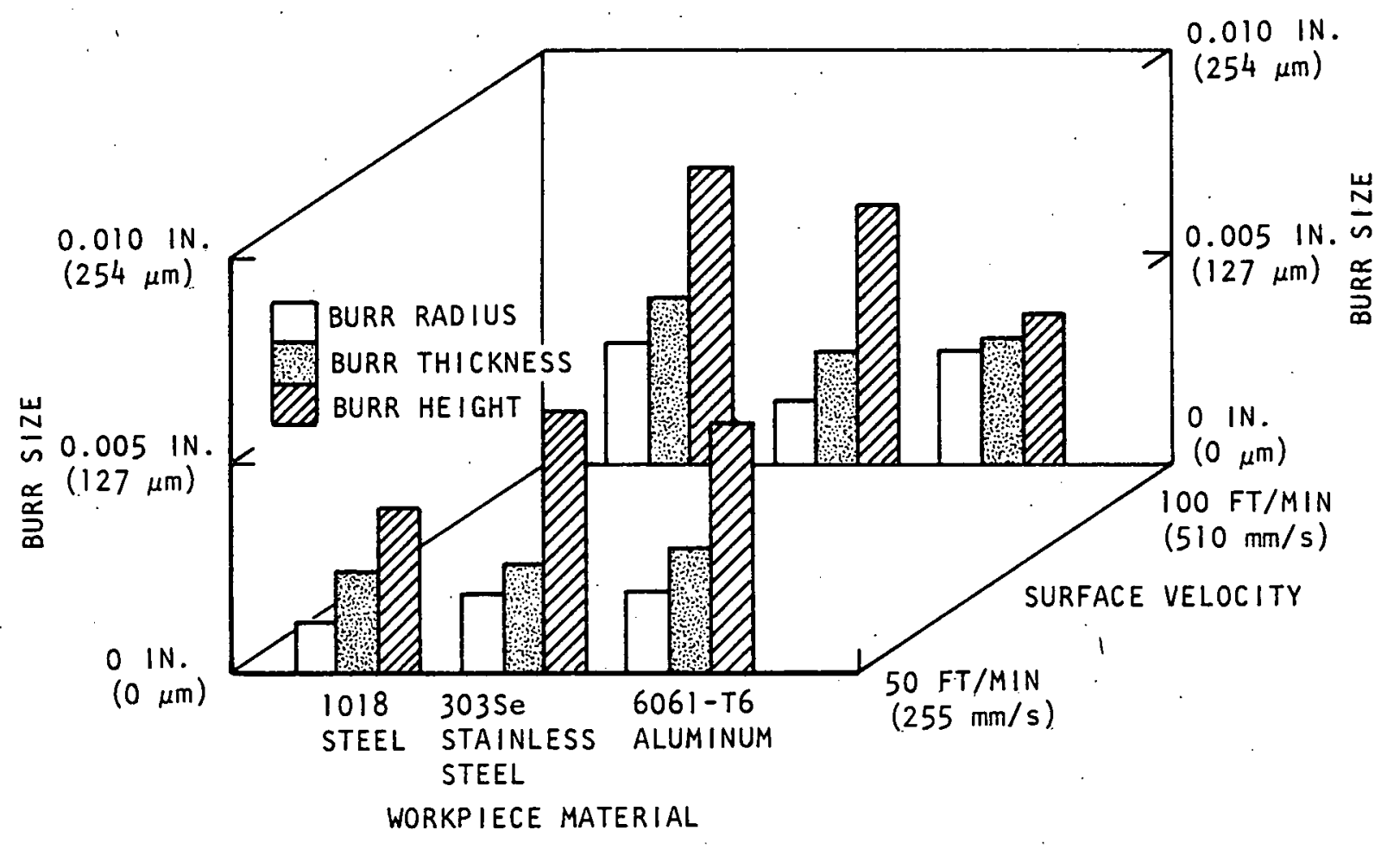

Figure 18. Effect of Workpiece Material and Surface Velocity on Exit-Burr Height, Radius, and Thickness

As previously described, ${ }^{1}$ the material below the drill point stretches and is pushed outward as the drill exits from the workpiece (Figure 33). The closer the drill point approaches the backside of the material, the greater the material deflects (Figures 34 through 36). The thickness of the material below the drill point decreases in a nonlinear fashion as the drill advances. Figures 37 and 38 show material deformation below the drill point, and the discontinuity of the metal shown in Figure 39 evidences a rapid tearing of the $17-4 \mathrm{PH}$ stainless steel. The data obtained during this portion of the study are shown in Table A-4 of the Appendix.

The Appearance of Drill-Exit Burrs

Drill-exit burrs can assume many shapes. The following descriptions and referenced figures illustrate the basic forms:

- Very short and uniform (Figure 40);

- Very long and uniform (Figures 41 and 42); 


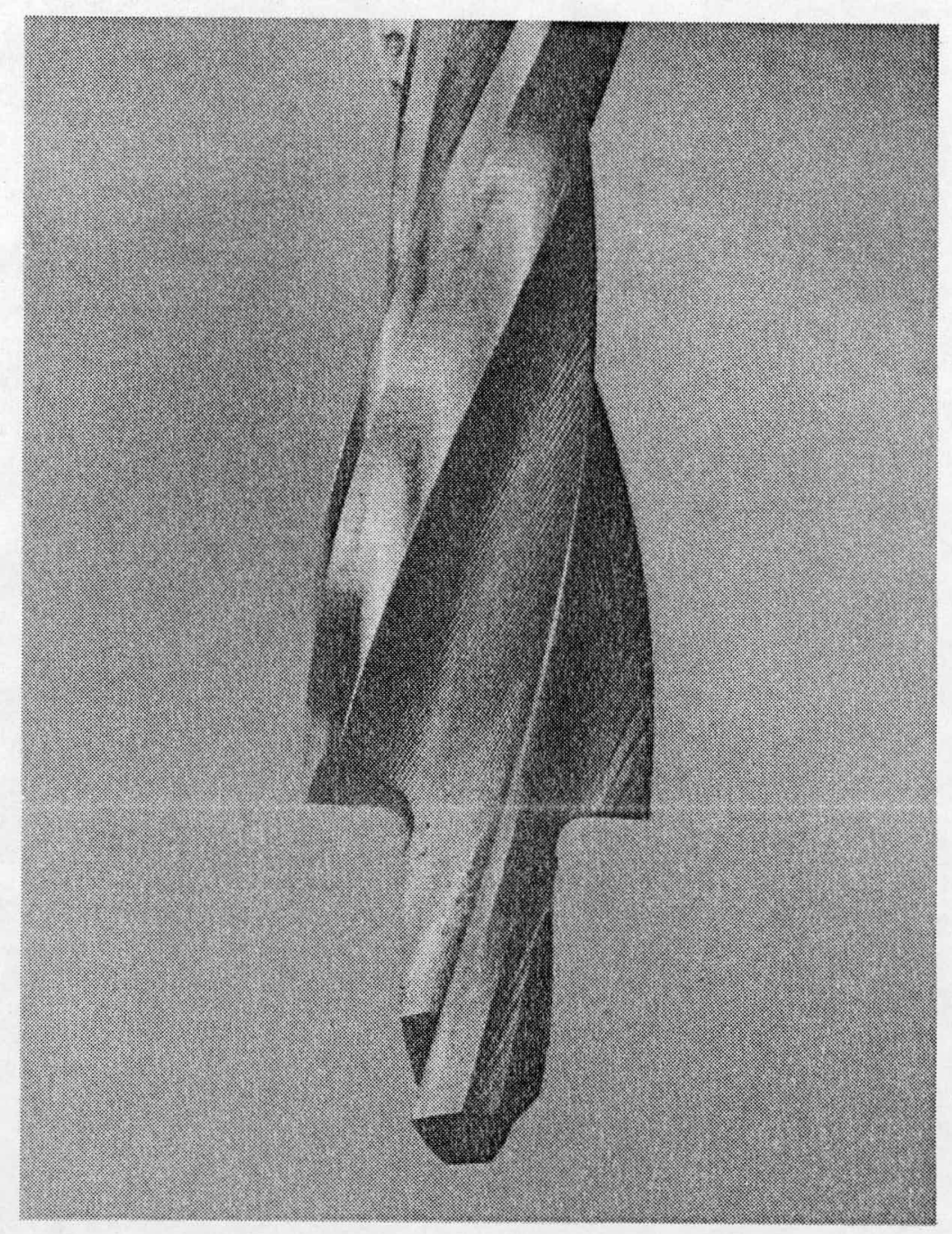

Figure 19. Subland Drill Point

- Extremely ragged (Figures 43 and 44); and

- Short, with a cap of metal (Figure 45).

Combinations between these extremes also are produced. As previously indicated, a great amount of variability occurs from one hole to the next. Figure 46, for example, illustrates two burrs that were produced, one after the other, using a hand-fed drill press. On the part shown, one burr is twice the length of the other. Figure 47 illustrates an extruded burr formed by drilling and boring a 0.0938 -inch $(2.38 \mathrm{~mm}$ ) hole in beryllium-copper. After a twenty-minute cycle in a Harperizer, the thick, uniform burr is still obvious. As illustrated by these photographs, burr-height measurements can be subject to a large amount of variability: The impact of this variability has been described elsewhere. ${ }^{2}$ \& 


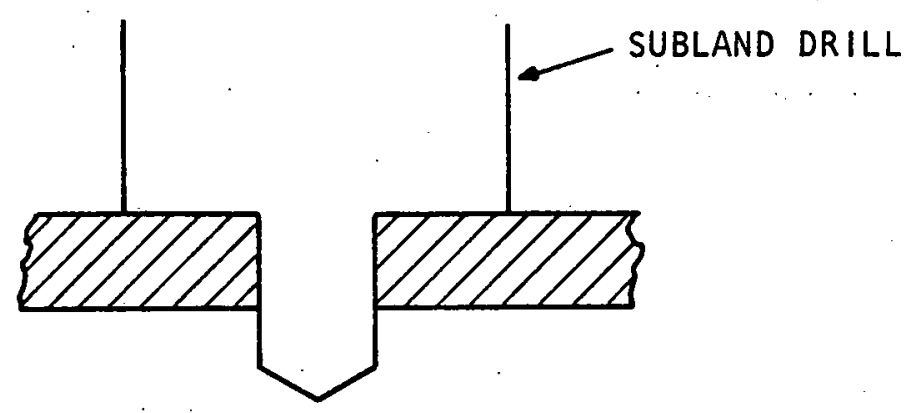

DESIRED CONDITION

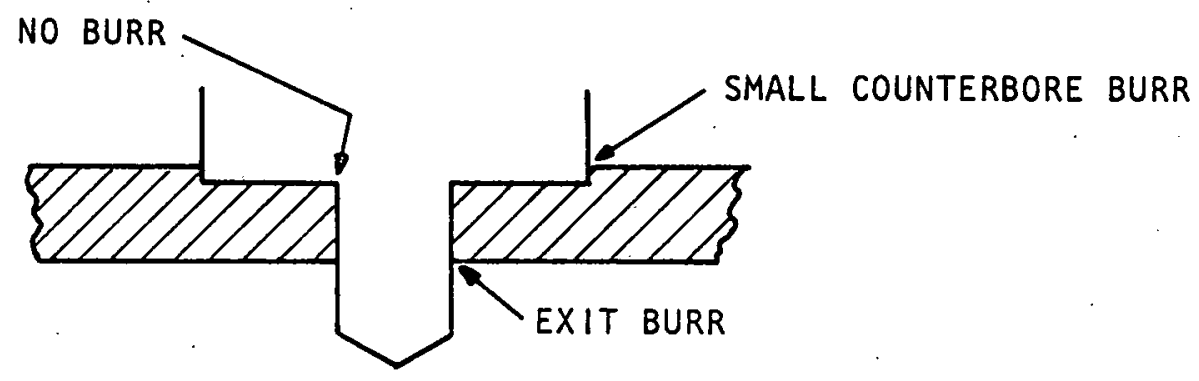

ACTUAL CONDITION

Figure 20. Desired and Actual Burr

Conditions When Subland Drill

Is Used

\section{Analysis of Recently Published Reports}

Since the first report ${ }^{1}$ in this series was prepared, four other publications have appeared on the subject of burrs produced by drilling. In addition to these, at least two other individuals have initiated studies on the subject.

In the first of these recent reports, ${ }^{18}$ the effect of coolants on burrs produced from stacks of different aerospace materials was evaluated. Burr height and thickness were monitored on both the entrance and exit sides of 0.5-inch-diameter (12.7 $\mathrm{mm})$ holes. All drills used in the study were oil-hole drills. Conclusions were based on the results obtained from 520 measurements of burrs produced by drills and reamers in titanium, aluminum, and 4130 steel. 
Table 4. Comparison of Burrs Produced by Subland Drills With Those Produced by Conventional Drills

\begin{tabular}{|c|c|c|c|c|c|}
\hline \multirow[b]{2}{*}{ Material } & \multirow[b]{2}{*}{$\begin{array}{l}\text { Burr } \\
\text { Type }\end{array}$} & \multirow[b]{2}{*}{$\begin{array}{l}\text { Drill } \\
\text { Type. }\end{array}$} & \multicolumn{3}{|c|}{ Typical Burr Properties* } \\
\hline & & & $\begin{array}{l}\text { Height } \\
(\text { Inch }) * *\end{array}$ & $\begin{array}{l}\text { Thick- } \\
\text { ness } \\
\text { (Inch) }\end{array}$ & $\begin{array}{l}\text { Radius } \\
\text { (Inch). }\end{array}$ \\
\hline \multirow[t]{3}{*}{1018 Steel } & Entrance & $\begin{array}{l}\text { 4-Facet } \\
\text { Subland }\end{array}$ & $\begin{array}{l}0.0013 \\
0.0004\end{array}$ & $\begin{array}{l}0.0014 \\
0.0009\end{array}$ & $\begin{array}{l}0.0012 \\
0.0014\end{array}$ \\
\hline & Counterbore & Subland & 0.0007 & 0.0020 & 0.0012 \\
\hline & Exit & $\begin{array}{l}\text { 4-Facet } \\
\text { Subland }\end{array}$ & $\begin{array}{l}0.0045 \\
0.0073\end{array}$ & $\begin{array}{l}0.0020 \\
0.0033\end{array}$ & $\begin{array}{l}0.0012 \\
0.0042\end{array}$ \\
\hline \multirow[t]{3}{*}{$303 \mathrm{Se}$ SST } & Entrance & $\begin{array}{l}\text { 4-Facet } \\
\text { Subland }\end{array}$ & $\begin{array}{l}0.0012 \\
0.0006\end{array}$ & $\begin{array}{l}0.0021 \\
0.0010\end{array}$ & $\begin{array}{l}0.0017 \\
0.0013\end{array}$ \\
\hline & Counterbore & Subland & 0.0010 & 0.0018 & 0.0015 \\
\hline & Exit & $\begin{array}{l}\text { 4-Facet } \\
\text { Subland }\end{array}$ & $\begin{array}{l}0.0024 \\
0.0038\end{array}$ & $\begin{array}{l}0.0025 \\
0.0045\end{array}$ & $\begin{array}{l}0.0023 \\
0.0044\end{array}$ \\
\hline \multirow[t]{3}{*}{ 6061-T6 Al } & Entrance & $\begin{array}{l}\text { 4-Facet } \\
\text { Subland }\end{array}$ & $\begin{array}{l}0.0018 \\
0.0008\end{array}$ & $\begin{array}{l}0.0027 \\
0.0019\end{array}$ & $\begin{array}{l}0.0026 \\
0.0022\end{array}$ \\
\hline & Counterbore & Subland & 0.0015 & 0.0039 & 0.0035 \\
\hline & Exit & $\begin{array}{l}\text { 4-Facet } \\
\text { Subland }\end{array}$ & $\begin{array}{l}0.0038 \\
0.0144\end{array}$ & $\begin{array}{l}0.0032 \\
0.0036\end{array}$ & $\begin{array}{l}0.0022 \\
0.0020\end{array}$ \\
\hline
\end{tabular}

*Feedrate $=0.001 \mathrm{ipr}(25.4 \mu \mathrm{m} / \mathrm{rev}) ;$ surface velocity of the 0.140 inch-diameter $(3.556 \mathrm{~mm})$ subland drill was $27.5 \mathrm{ft} / \mathrm{min}(140 \mathrm{~mm} / \mathrm{s})$; surface velocity of the conventional drills was $50 \mathrm{ft} / \mathrm{min}(255 \mathrm{~mm} / \mathrm{s})$. $* * 0.001$ inch $=25.4 \mu \mathrm{m}$. 


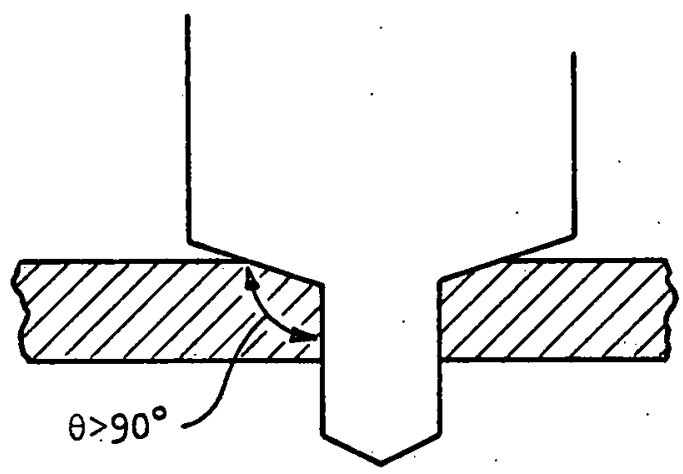

Figure 21. Subland-Drill

Transition Angle to Minimize Counterbore Burr

In the study, one of ten coolant-application combinations was found to minimize the burr size. With this coolant, both the entrance and exit burrs from titanium tended to be approximately 0.003 inch $(76.2 \mu \mathrm{m})$ in height and 0.010 inch $(0.25 \mathrm{~mm})$ in thickness. Burrs from 4130 steel were less than 0.001 inch $(25.4 \mu \mathrm{m})$ high and from 0.002 to 0.005 inch (50.8 to $127.0 \mu \mathrm{m})$ thick.

The second recent report ${ }^{19}$ is a continuation of the tests described in the previous reference. The tests, however, included the influence of speed, feed, and drill geometry, and the results were based on 2600 burr measurements.

In the study, high feedrates and speeds were found to have little effect on burr size. Burrs from 2024-T351 aluminum were much smaller than those from $\mathrm{Ti}-6 \mathrm{~A} 1-4 \mathrm{~V}$ titanium, $\mathrm{PH}-13-8$ stainless steel, or HP-9 $\mathrm{Ni}-4$ Co steel. Holes drilled without the coolant were only slightly larger than those drilled using the coolant.

Drill-point geometry was found to have little effect on burr properties; tool sharpness was the most significant element in determining burr size. Exit burrs from reaming were higher than those from drilling. For many of the specimens, removing the drilling burrs lowered the fatigue strength of the sample.

In the third report ${ }^{2}$ ' of Phillips' series, the burrs formed between two stacked plates were found to be much more consistent than those formed at either the entrance or the exit of holes in single plates. 
Table 5. Drilling Conditions Used in Subland-Drill Experiments

\section{Level}

Condition

A Feedrate

(IPR)*

B Spindle Speed

(RPM)

C Material
1

0.001

375

303Se SST
2

0.003

$* 0.001$ ipr $=25.4 \mu \mathrm{m} / \mathrm{rev}$.

Hasegawa, Zaima, and Yuki's work ${ }^{7}$ on drilling aluminum indicates that exit-burr thickness increases with the feedrate, decreases substantially with the helix angle, and is relatively unaffected by the lip-clearance angle. Burr thickness is a nonlinear function of the point angle; angles less than 75 degrees and greater than 150 degrees result in the thinnest burrs. The point angle at the corners of the drill rather than the angle at the chisel edge is more significant in determining the burr height. In the tests, burr thickness was not affected by the cutting speed. The use of carbon tetrachloride as a coolant resulted in burrs half the thickness of those produced using
water-soluble oil.

Yuki's study ${ }^{30}$ of burrs produced by drilling and through-hole boring of aluminum indicates that burr thickness decreases slightly with an increased end-relief angle and decreases dramatically with an increased back-rake angle. The equivalent side-cutting-edge-angle in boring affects exit-burr thickness in the form of a third-order equation; a 20-degree angle produces the thinnest burr. Burr thickness increases with an increased feedrate and depth-of-cut, decreases with the drill-point angle, and, in the case of boring-burrs, it decreases slightly as the
cutting speed is increased.

The use of carbon tetrachloride as a coolant results in the thinnest burrs. When a drill is used to enlarge an existing hole, the burr thickness becomes a third-order function of the diameter of the initial hole. In boring, the thickness decreases with a decrease in the radial rake angle. 
Table 6. Analysis-Of-Variance Summary of Significant Effects for Subland Drills

\begin{tabular}{|c|c|c|c|c|}
\hline \multirow[b]{2}{*}{ Conditions* } & \multirow[b]{2}{*}{ Burr Type } & \multicolumn{3}{|c|}{ Significant Effects } \\
\hline & & Thickness & Length & Radius \\
\hline$A$ & $\begin{array}{l}\text { Entrance } \\
\text { Counterbore } \\
\text { Exit }\end{array}$ & $\begin{array}{l}* * \\
* * * *\end{array}$ & $* *$ & ** \\
\hline B & $\begin{array}{l}\text { Entrance } \\
\text { Counterbore } \\
\text { Exit }\end{array}$ & $\begin{array}{l}* * \\
* *\end{array}$ & $* *$ & \\
\hline C & $\begin{array}{l}\text { Entrance } \\
\text { Counterbore } \\
\text { Exit }\end{array}$ & $\begin{array}{l}* * * \\
* * *\end{array}$ & $\begin{array}{l}* * * \\
* *\end{array}$ & $* * *$ \\
\hline $\mathrm{AB}$ & $\begin{array}{l}\text { Entrance } \\
\text { Counterbore } \\
\text { Exit }\end{array}$ & & $* *$ & \\
\hline $\mathrm{AC}$ & $\begin{array}{l}\text { Entrance } \\
\text { Counterbore } \\
\text { Exit }\end{array}$ & & & \\
\hline $\mathrm{BC}$ & $\begin{array}{l}\text { Entrance } \\
\text { Counterbore } \\
\text { Exit }\end{array}$ & & $* *$ & \\
\hline $\mathrm{ABC}$ & $\begin{array}{l}\text { Entrance } \\
\text { Counterbore } \\
\text { Exit }\end{array}$ & & & \\
\hline $\begin{array}{r}\text { *Conditions } \\
\text { **Significant } \\
* * * \text { Significant } \\
\text { ****Significant }\end{array}$ & $\begin{array}{l}\text { indicated by } \\
\text { effect at } 95 \\
\text { effect at } 99 \\
\text { effect at a }\end{array}$ & $\begin{array}{l}\text { etters are } \\
\text { percent cont } \\
\text { oercent con } \\
\text { onfidence } 1 \epsilon\end{array}$ & $\begin{array}{l}\text { tified i } \\
\text { nce leve } \\
\text { nce leve } \\
\text { exceedi }\end{array}$ & $\begin{array}{l}\text { Table } 5 . \\
99 \text { perc }\end{array}$ \\
\hline
\end{tabular}

In another study ${ }^{3}$ which was published in 1945 but just recently discovered, Okoshi and others noted that 60-degree point angles produced larger burrs than those produced by larger point angles. Burrs produced at a spindle speed of 10,000 rpm were smaller than those produced at a speed of $1120 \mathrm{rpm}$.

In addition to the test results just described, additional studies have developed a mathematical theory of drilling-burr formation with equations to provide a rationale for predicting burr size.32,3 


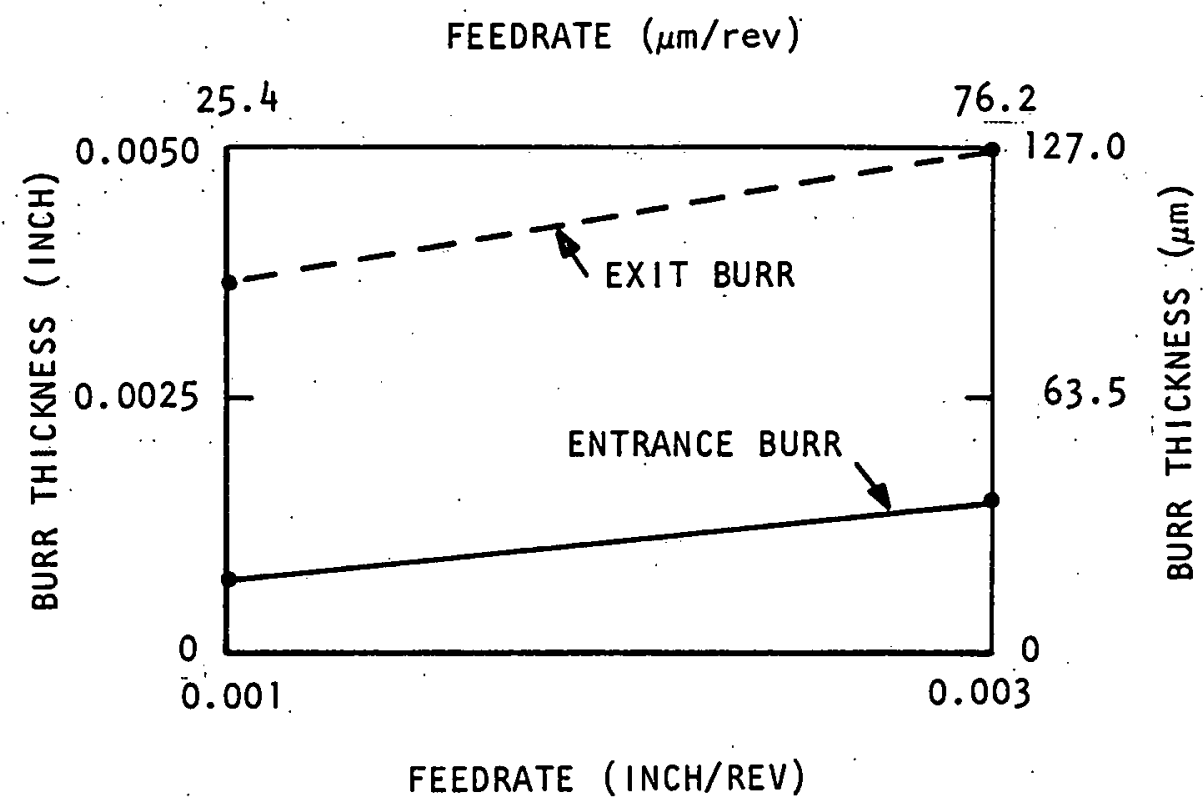

Figure 22. Effect of Subland-Drill Feedrate on Burr Thickness

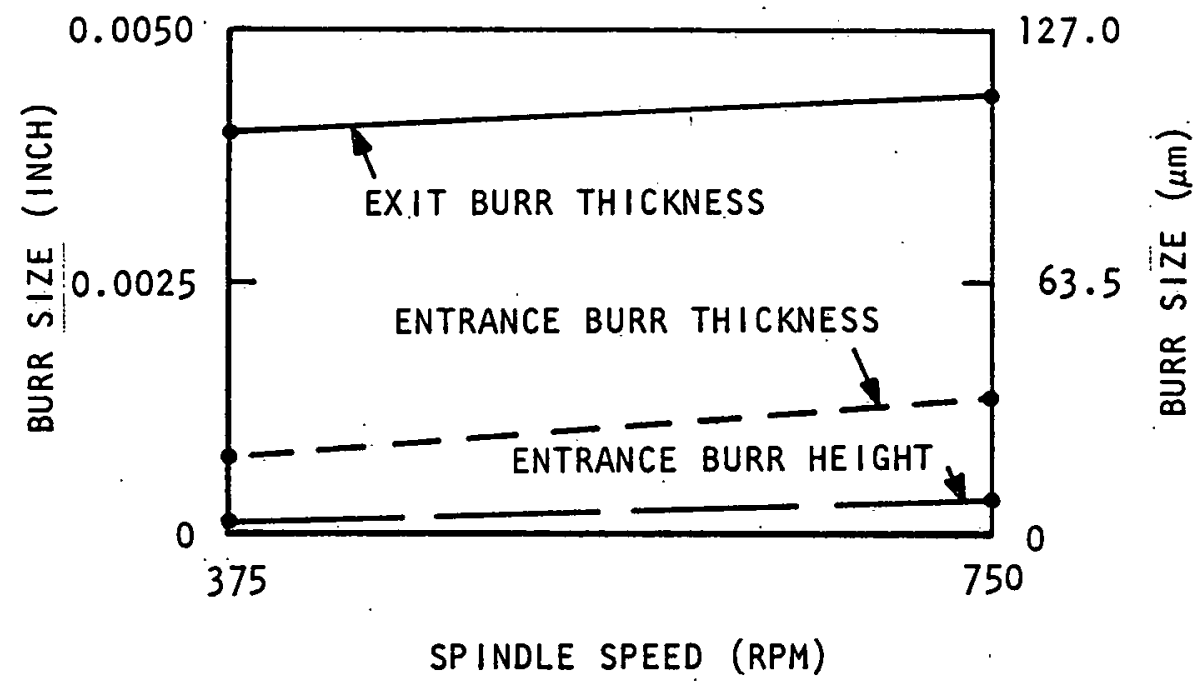

Figure 23. Effect of Subland-Drill Spindle Speed on Bürr Size 


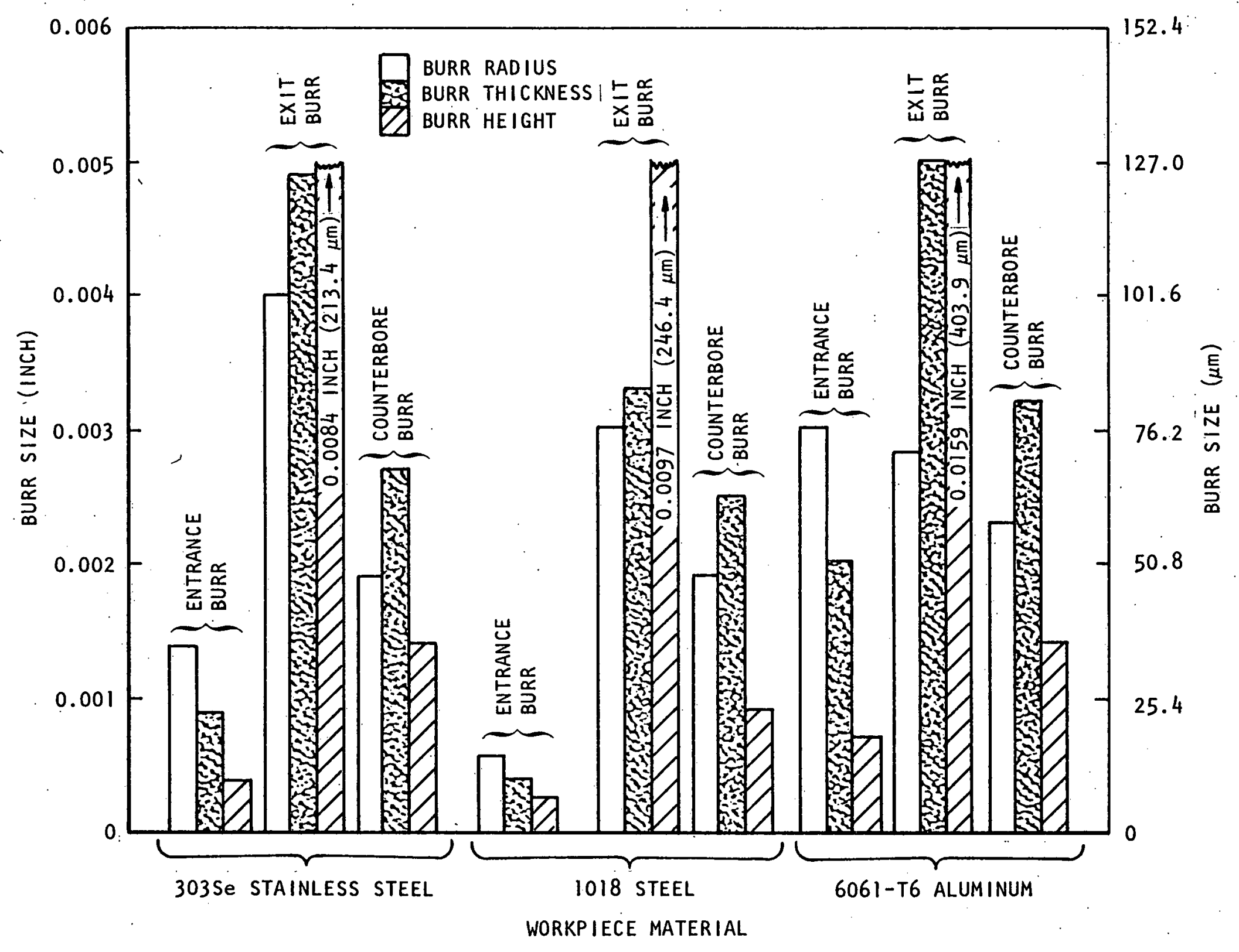

Figure 24. Effect of Workpiece Material on Subland-Drill-Burr Size 
Table 7. Drilling Conditions Used in Drill-Wear Study

\begin{tabular}{ll}
\hline Workpiece Material & $\begin{array}{l}\text { Spindle } \\
\text { Speed* } \\
\text { (RPM) }\end{array}$ \\
\hline 1018 Steel $\left(\mathrm{R}_{\mathrm{B}} 90\right)$ & 2000 \\
303 Se Stainless Steel ( $\left.\mathrm{R}_{\mathrm{C}} 33\right)$ & 3000 \\
$6061-\mathrm{T} 6$ Aluminum $\left(\mathrm{R}_{\mathrm{B}} 55\right)$ & 4000 \\
\hline *All feedrates for this test were \\
maintained at 0.003 ipr $(76 \mu \mathrm{m} / \mathrm{rev})$. \\
\hline
\end{tabular}

\section{Production Implications}

From the studies described in this report, the following conclusions have been drawn concerning the utilization of these results in the production of parts.

Material Influences

- Exit burrs from 303Se stainless steel are typically higher than those from 1018 steel.

- Exit burrs from 6061-T6 aluminum are typically shorter than those from either 1018 steel or 303Se stainless steel.

- Burrs from 17-4PH stainless steel tend to be smaller than those from other steels.

Speed and Feedrate Influences

- Increasing the surface velocity of drills from 50 to $100 \mathrm{sfpm}$ (255 to $510 \mathrm{~mm} / \mathrm{s}$ ) results in a 40-percent increase in the thickness of both entrance and exit burrs.

- The radii of both entrance and exit burrs increase by 40 percent as the surface velocity doubles.

- Increasing the feedrate from 0.001 to 0.003 ipr (25.4 to $76.2 \mu \mathrm{m} / \mathrm{rev}$ ) increases the entrance- and exit-burr thickness by. 40 percent. 


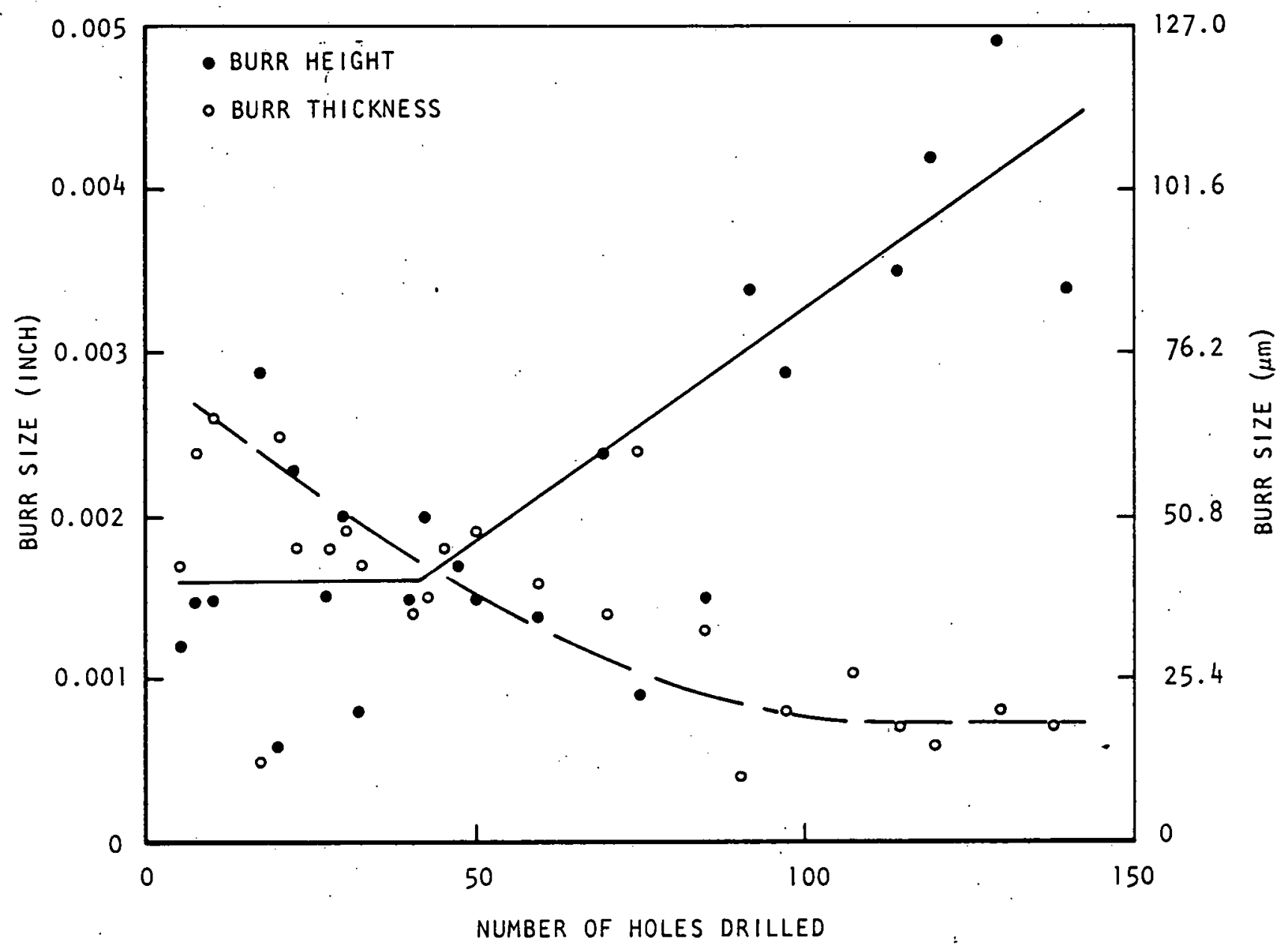

Figure 25. Effect of Number of Holes Drilled on Entrance-Burr Size Using Radial-Lip Drill in 6061-T6 Aluminum $\left(\mathrm{R}_{\mathrm{B}} 55\right)$

\section{Drill-Point Geometry Influences}

- The radial-lip drill point did not result in smaller burrs being produced in the short-run tests (effect-of-geometry tests), but it did result in smaller burrs in the drill-wear tests when 303Se stainless steel was drilled. This implies that when more than 50 holes are drilled in 303 Se stainless steel with a single drill, the radial-lip point should be used; no apparent advantage is obtained by the radial-lip point in short-run applications for the materials tested in this study.

- The use of drills with high helix angles (37-1/2 degrees) reduces burr height up to 50 percent, burr thickness up to 20 percent, and burr radius by 6 percent. 


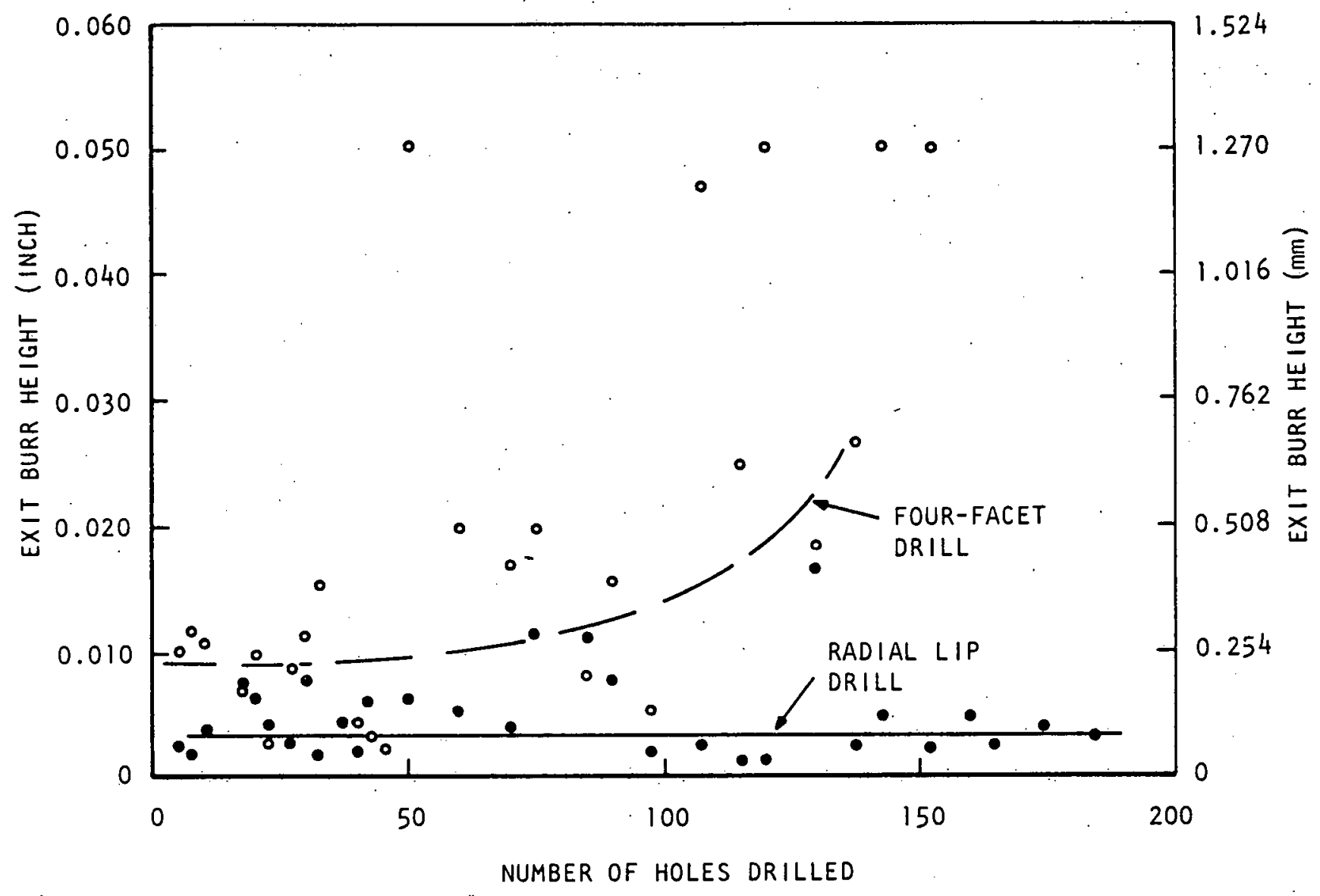

Figure 26. Effect of Number of Holes Drilled on Exit-Burr Height in 303Se Stainless Steel $\left(R_{C} 33\right)$

- Burr height increases with increased drill diameter.

\section{Other Influences}

- Subland drills can be used to minimize the size of entrance burrs. Their use, however, can increase tool costs by a factor of six, and it necessitates additional care in drilling to prevent objectionable spot-facing.

- With two exceptions, no noticeable change occurred in burr properties during the drilling of 150 holes. At different speeds and feedrates, however, noticeable changes can be expected.

- The size of burrs produced in drilling intersecting holes can be minimized by the use of a sacrificial backup-rod. Removing the rod can be a problem, however, because the burr which does form tends to capture the rod and may scratch the wall of the hole. 


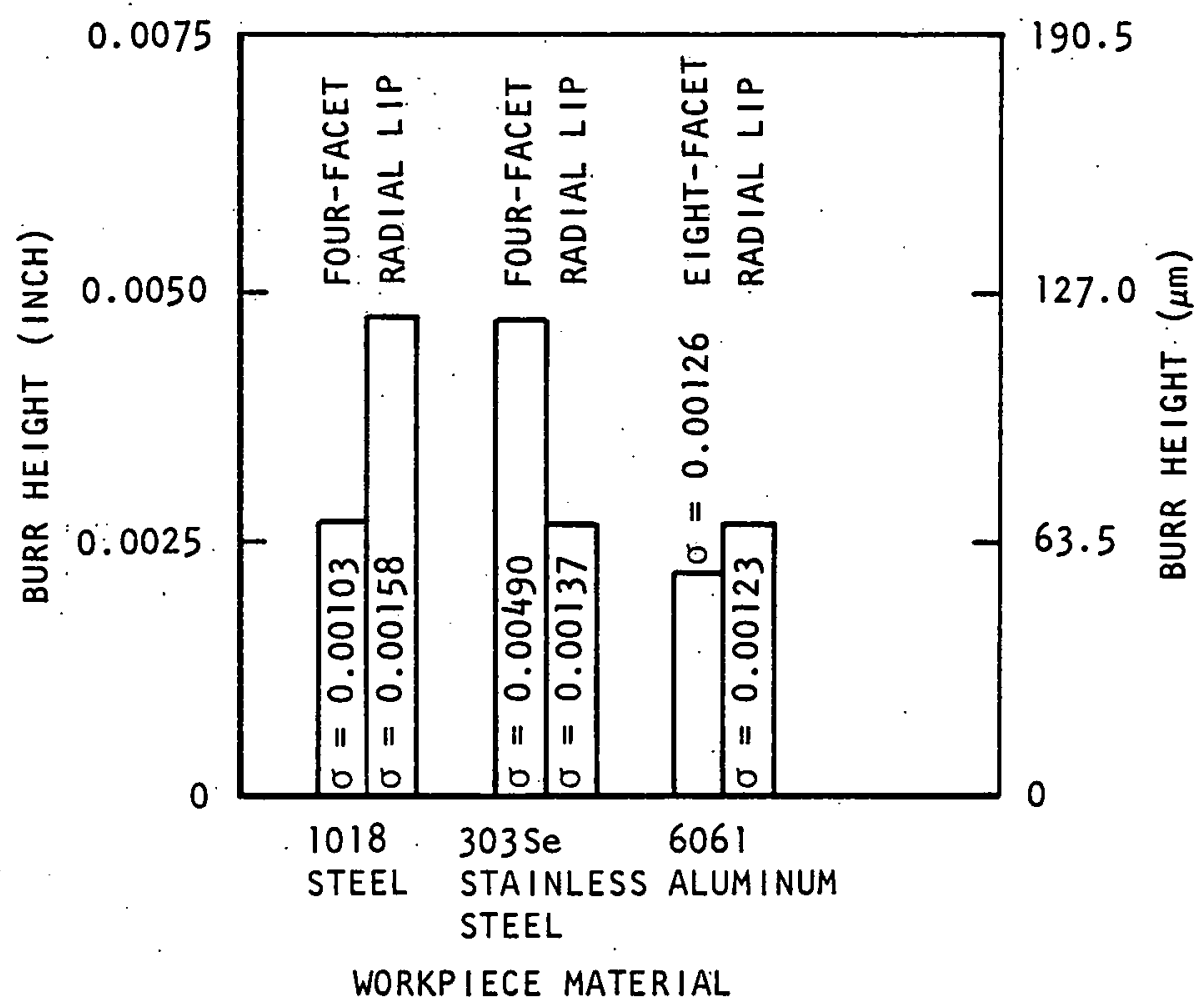

Figure 27. Effect of Drill-Point Geometry on Entrance-Burr Height (From DrillWear Study)

\section{Implications from Published Reports}

- The use of correct coolants can minimize burr size, but, in general, the difference between coolants is rather slight.

- Burrs from titanium tend to be short ( 0.003 to 0.010 inch or 76.2 to $254 \mu \mathrm{m})$ and very thick $(0.010$ inch or $254 \mu \mathrm{m})$.

- Tool sharpness is the single most significant factor in minimizing burr size.

The results of this study of drilling burrs, of the previous study, ${ }^{1}$ and of published observations are summarized in Tables 8 through 11. Specific production recommendations are presented in Tables 12 and 13.

In evaluating the effectiveness of the radial-lip drills, two factors should be noted. First, the principal advantage of the radial-lip drill is its longer tool life. The wear tests described in this report provided some support for the observation that tool wear (as evidenced by burr size) occurs at a slower 


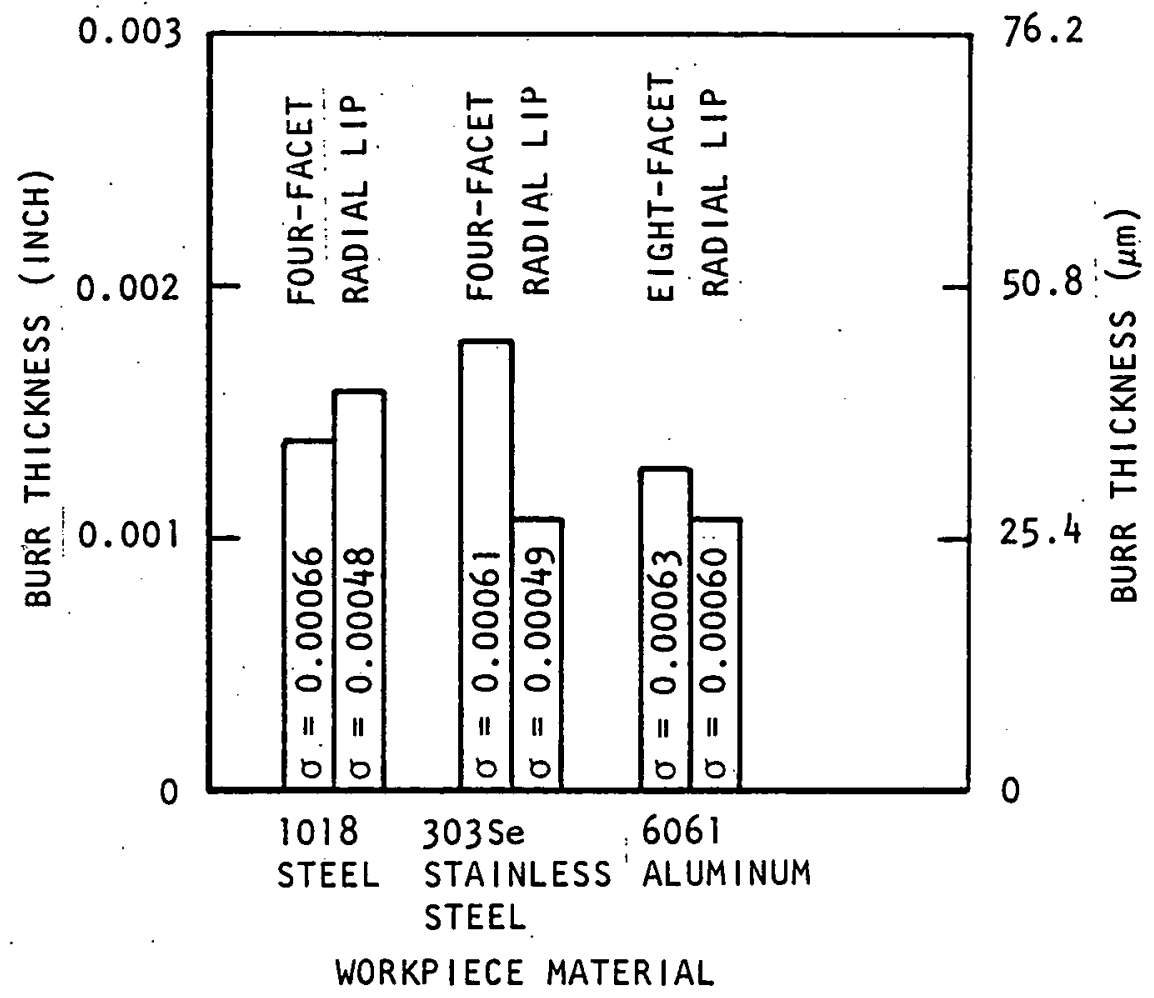

Figure 28. Effect of Drill-Point Geometry on Entrance-Burr Thickness (From Drill-Wear Study)

rate for this drill than for the more conventional drills. The real advantage of the radial-lip drill, however, appears to be for applications which require that more than 200 holes be made per drill.

The second factor that should be noted is that the feedrates used in this study were below those recommended by the manufacturer of radial-lip drills. Faster feedrates possibly would have shown a greater difference in performance between the drills. Table 14 presents the machining conditions recommended by the manufacturer of radial-lip drills and grinders.

The radial-lip drills used in this study were ground for the material in which they were to be used. Although it is not apparent, each material requires a slightly different radial geometry. At the time the studies were being performed, the smallest available size of drill on which a radial lip could be ground was 0.125 inch $(3.175 \mathrm{~mm})$. 


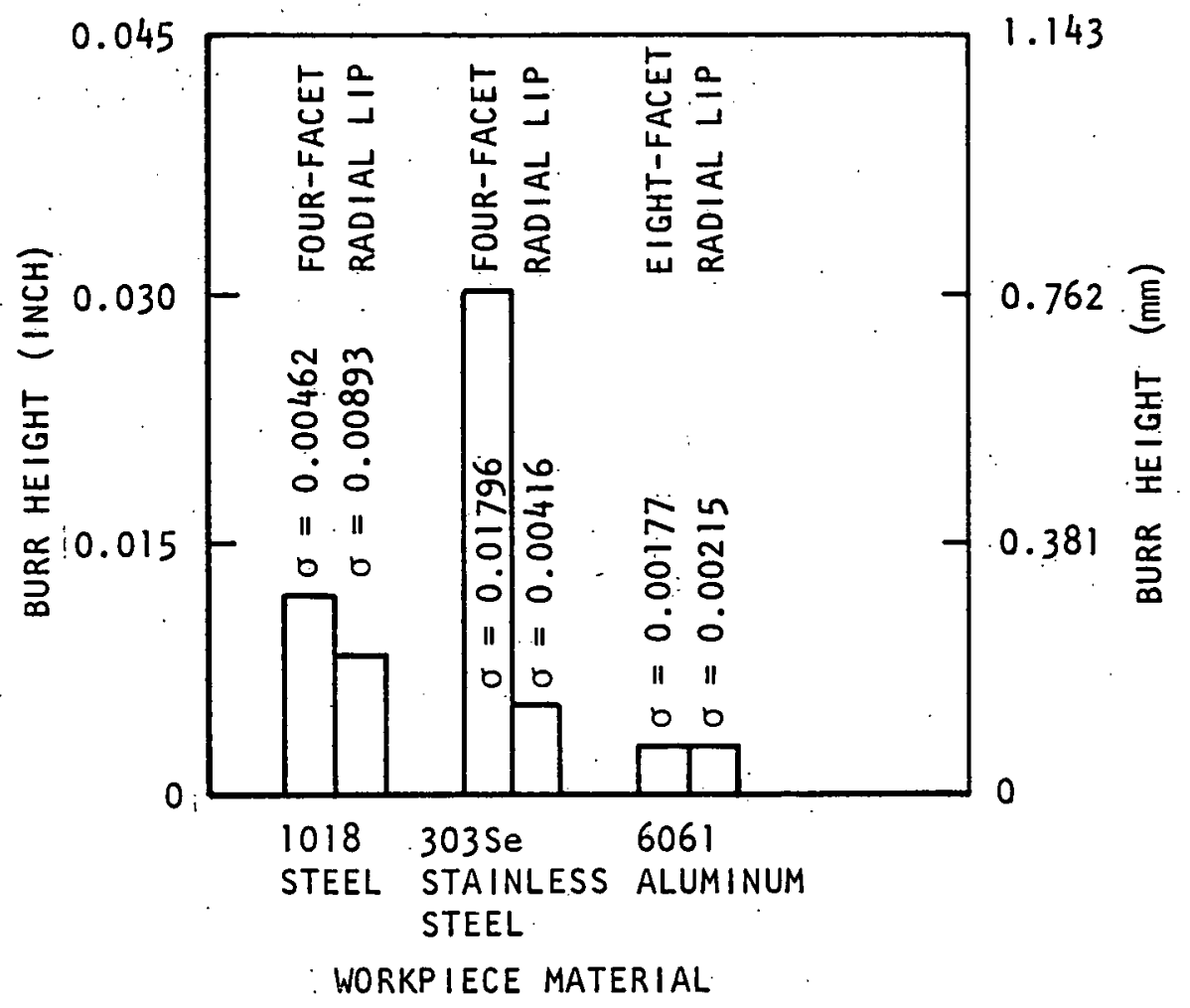

Figure 29. Effect of Drill-Point Geometry on Exit-Burr Height (From Drill-Wear Study)

\section{ACCOMPLISHMENTS}

The effects of feedrate, drill-point geometry, cutting velocity, helix angle, workpiece material, and drill wear have been evaluated for 0.125 - and $0.250-$ inch $(3.175$ and $6.350 \mathrm{~mm})$ drills. Subland drills have been proven capable of minimizing the size of entrance burrs. Drill wear, as indicated by burr size, was found to be negligible after producing 150 holes. The initial formation of the drill-exit burr has been documented by photographs of cross sections of the workpiece as the drill was breaking through the bottom surface. These results will assist engineers in selecting the manufacturing technique which will produce the smallest and most easily removed burrs for the desired application.

FUTURE WORK

Although no additional work on drilling burrs is planned, a study of the burrs produced by turning remains to be reported. Some additional work remains to be done in defining the capabilities of the various deburring processes. 


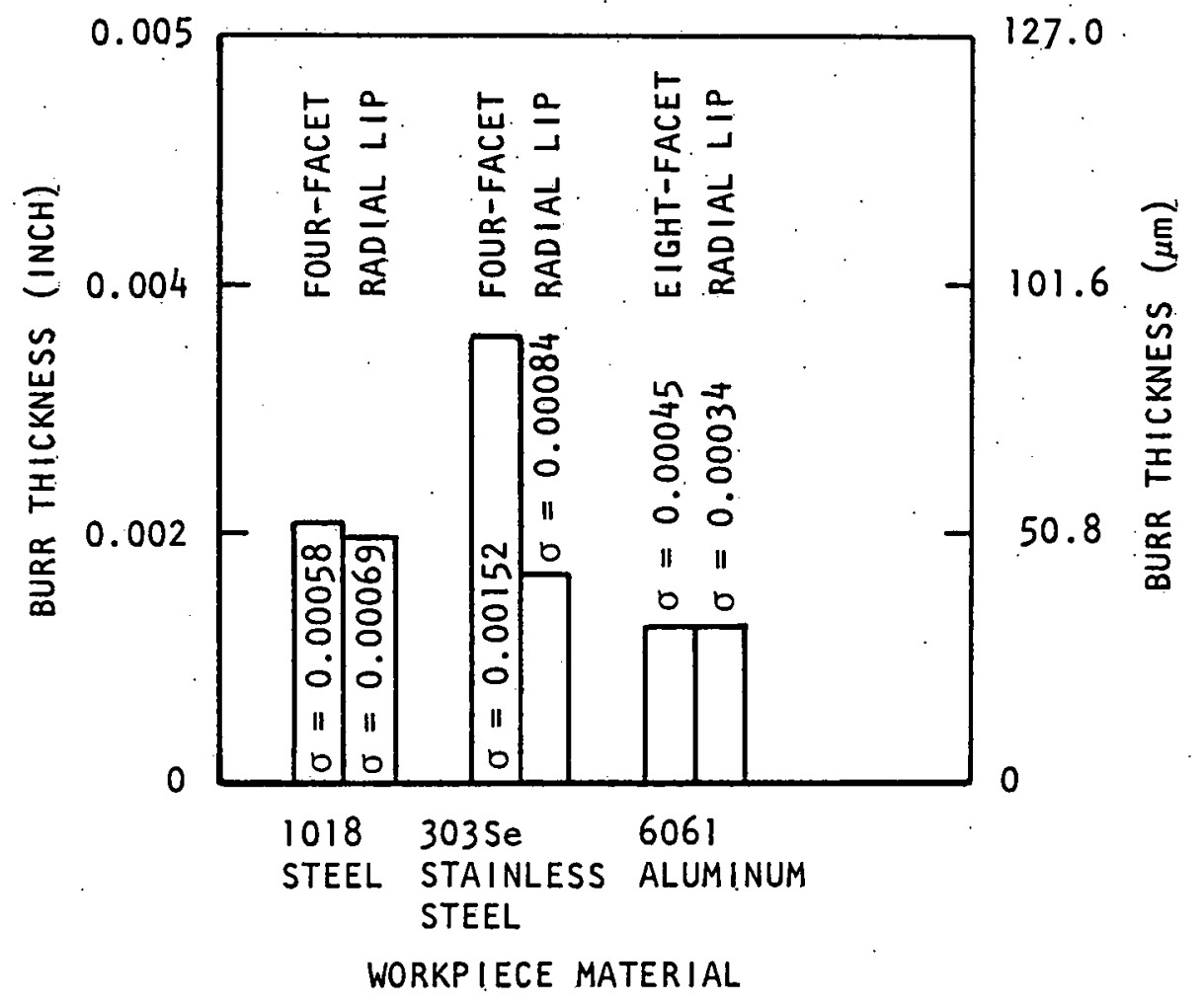

Figure 30. Effect of Drill-Point Geometry on Exit-Burr Thickness (From DrillWear Study)

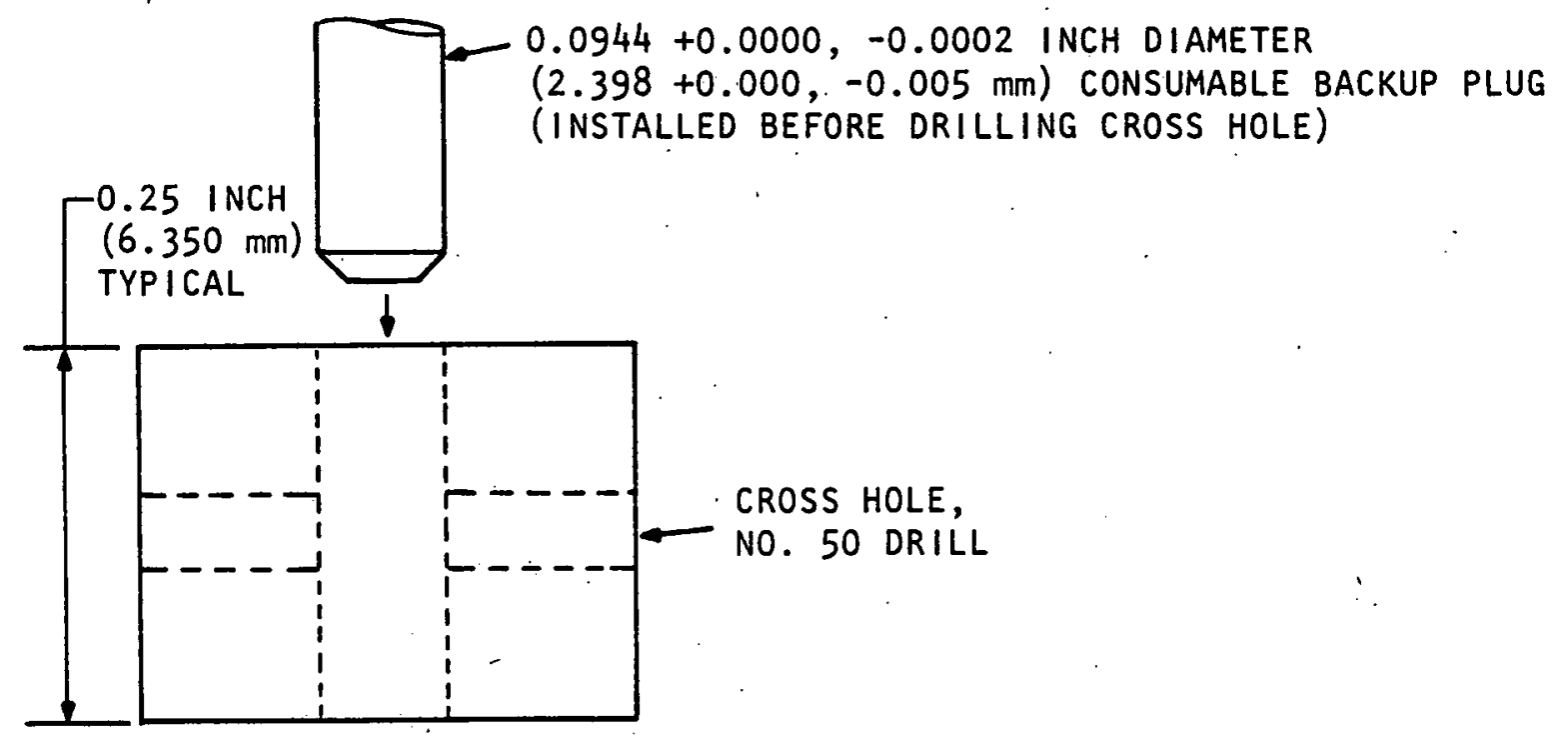

Figure 31. Test Sample With Consumable Backup Plug Used in Study of Cross-Hole-Burr Minimization 


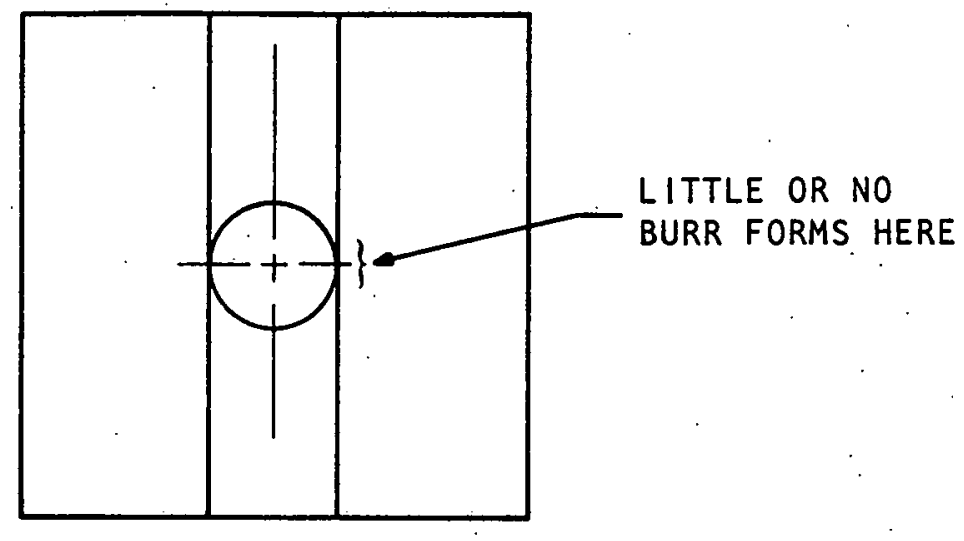

Figure 32. Minimization of Burr at Intersection of Two Holes of Equal Size

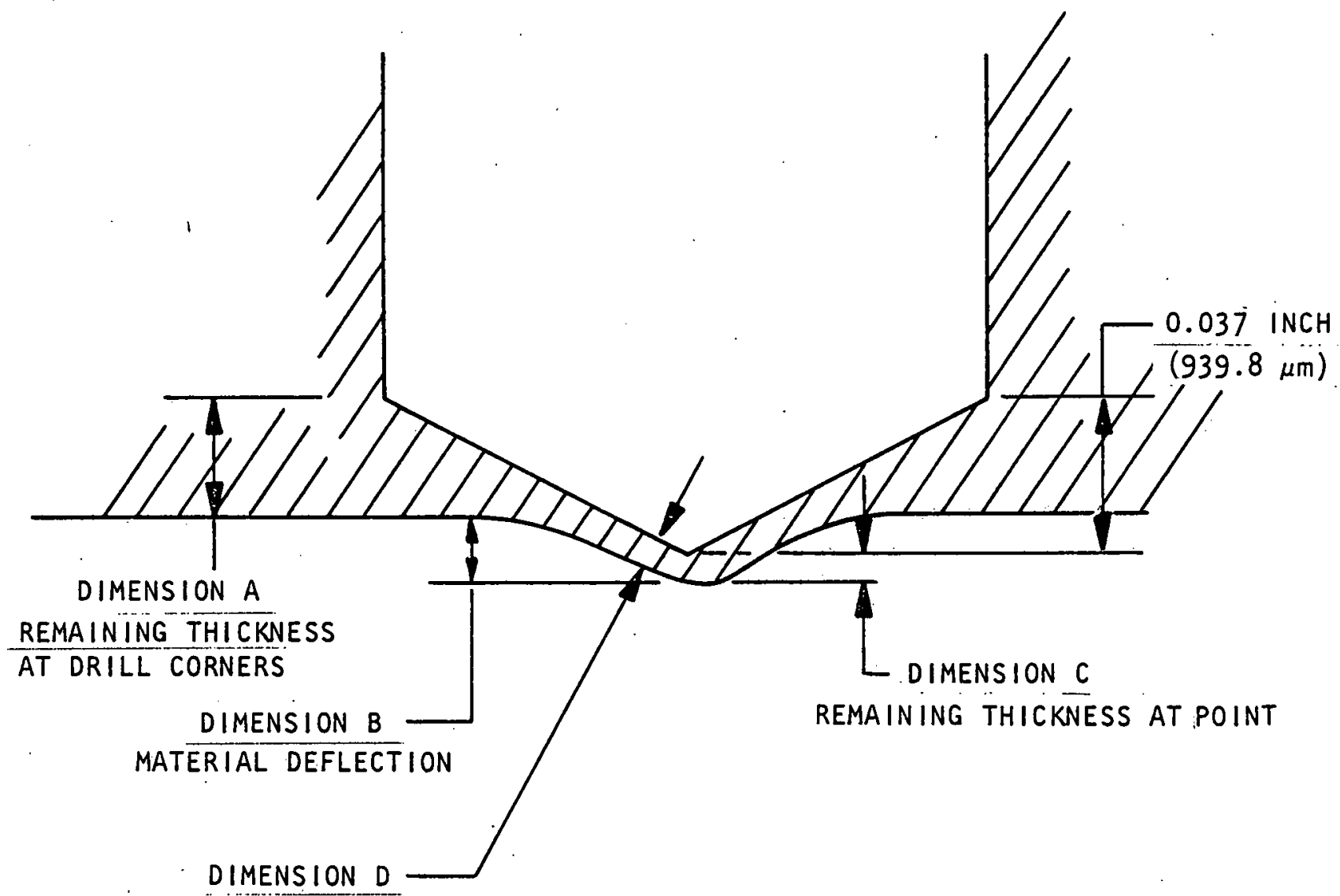

THICKNESS AT THINNEST POINT

Figure 33. Material Deflection Below Drill Point 


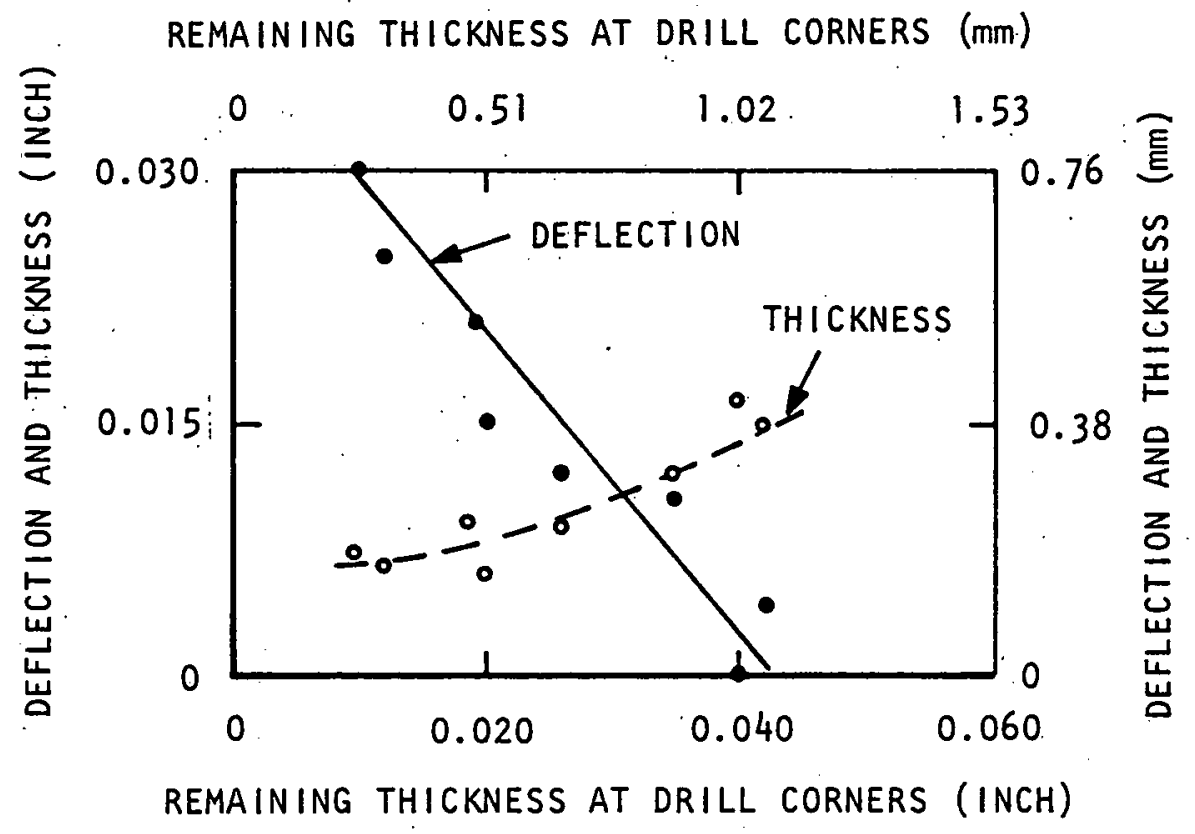

Figure 34. Deflection and Thickness of $303 \mathrm{Se}$ Stainless Steel Below Drill Point as Drill Exits

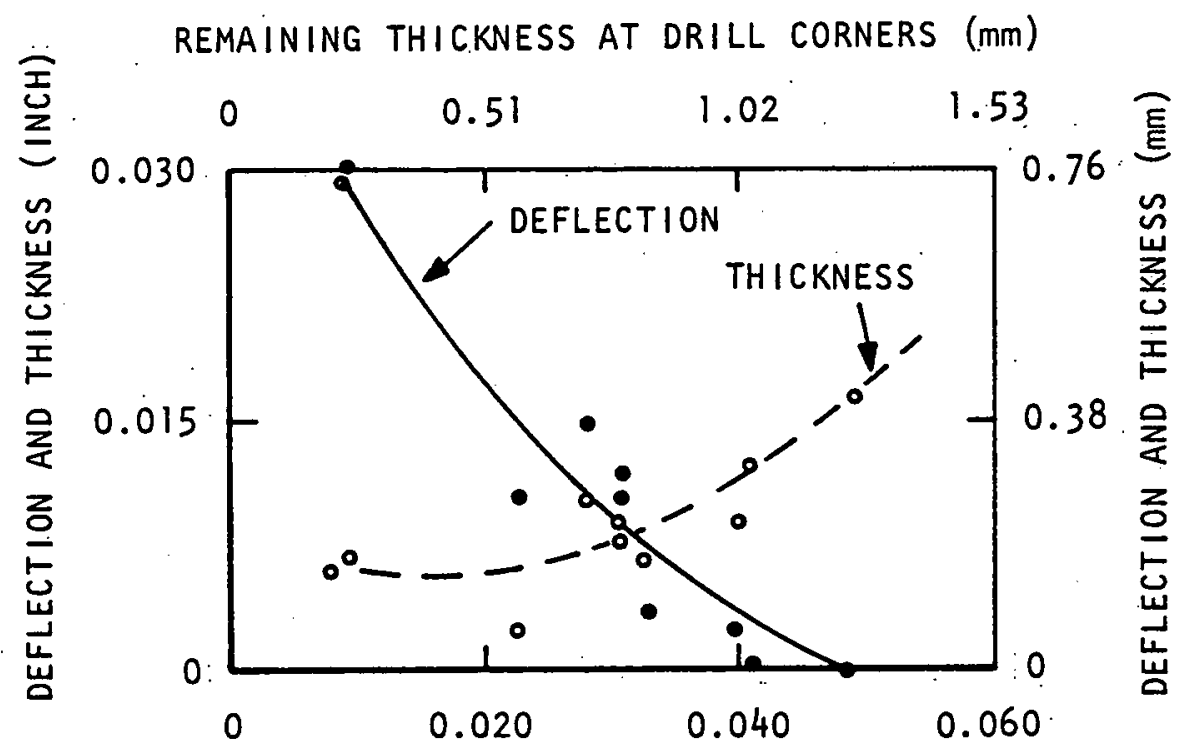

REMAINING THICKNESS AT. DRILL CORNERS (INCH)

Figure 35. Deflection and Thickness of 1018 Steel. Below Drill Point as Drill Exits 


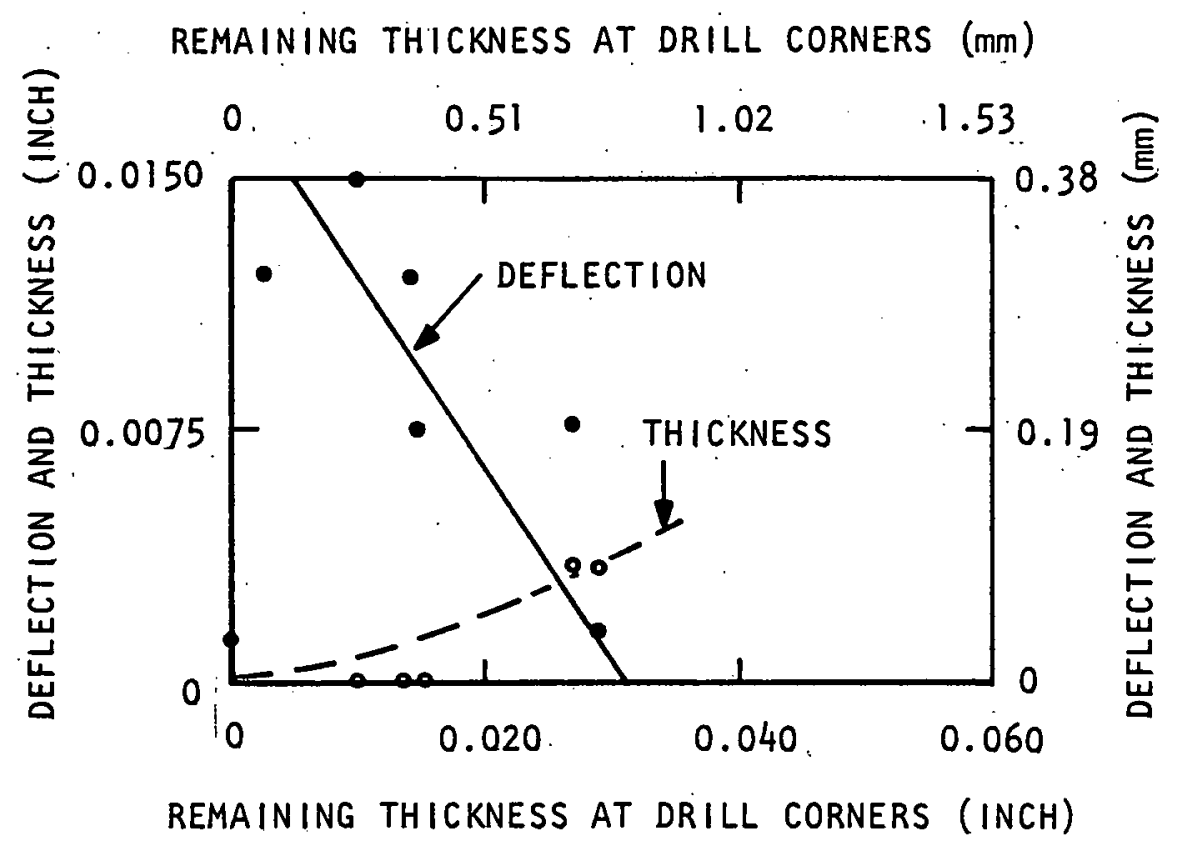

Figure 36. Deflection and Thickness of 17-4PH Stainless Steel (H9O0)

Below Drill Point as Drill Exits 


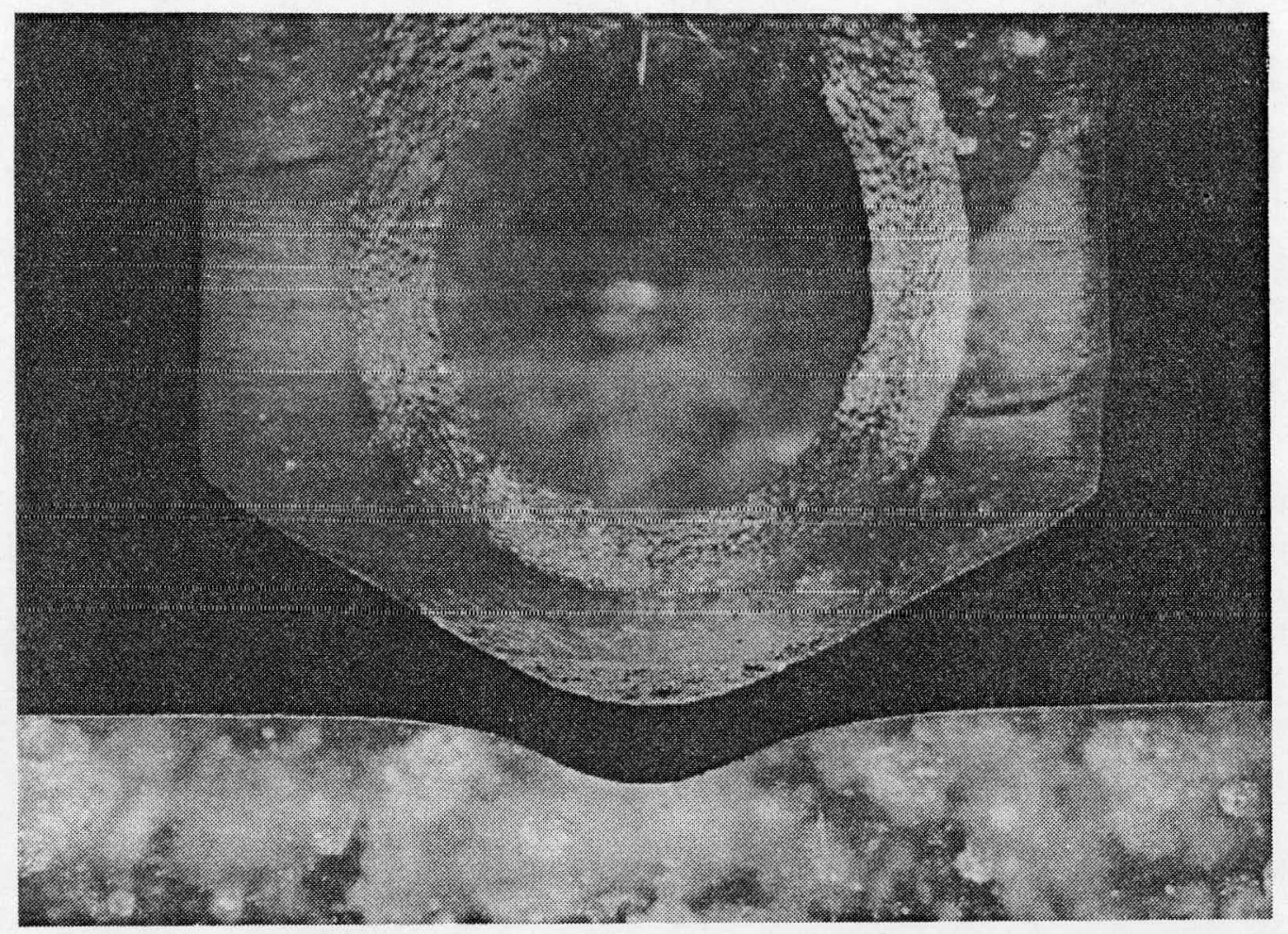

Figure 37. Material Deflection Below 0.125-InchDiameter ( $3.175 \mathrm{~mm}$ ) Drill Point in $303 \mathrm{Se}$ Stainless Steel (Specimen 14) 


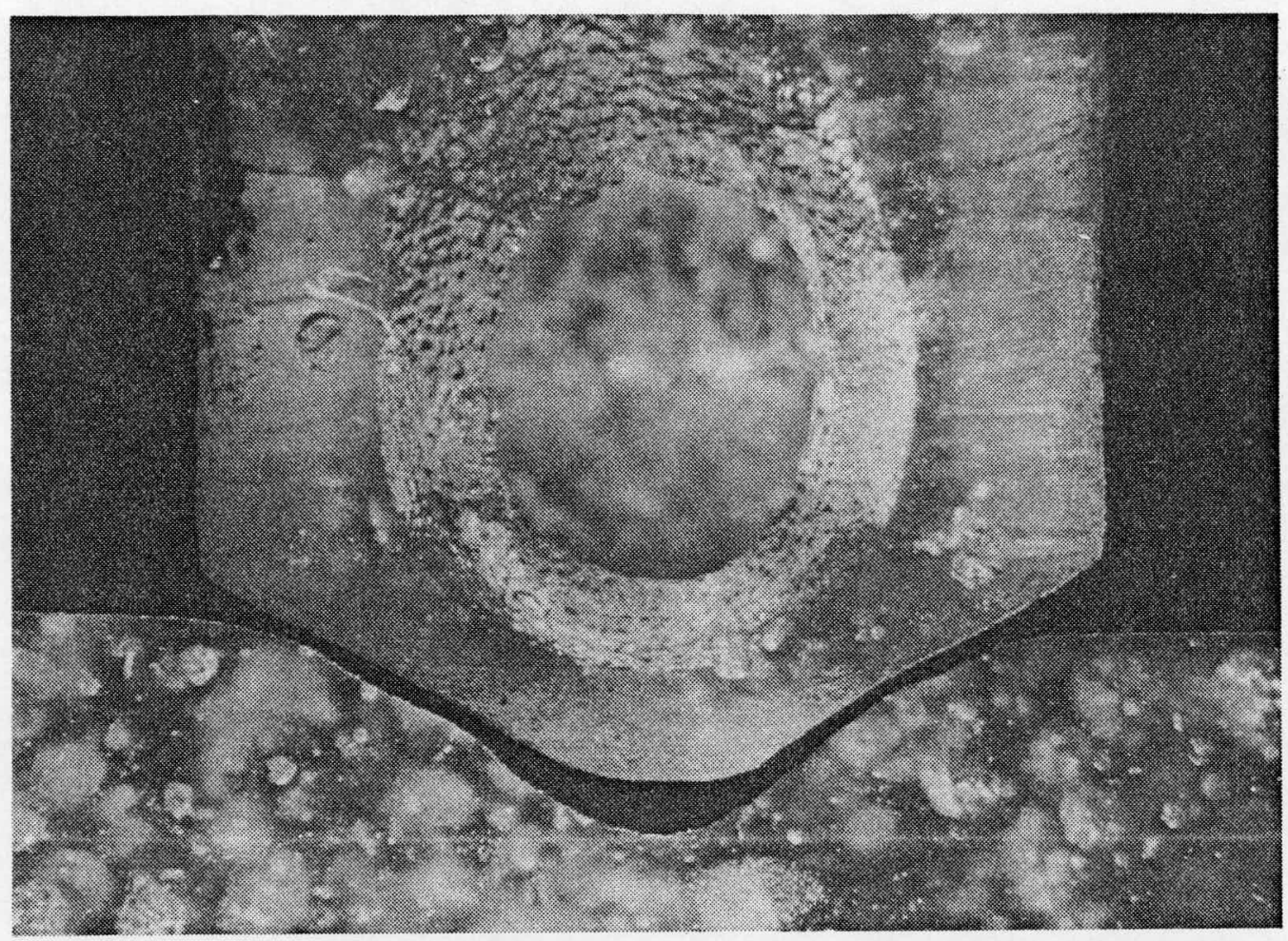

Figure 38. Material Deflection Below Drill Point as Drill Nears Breakthrough in 303Se Stainless Steel (Specimen 25) 


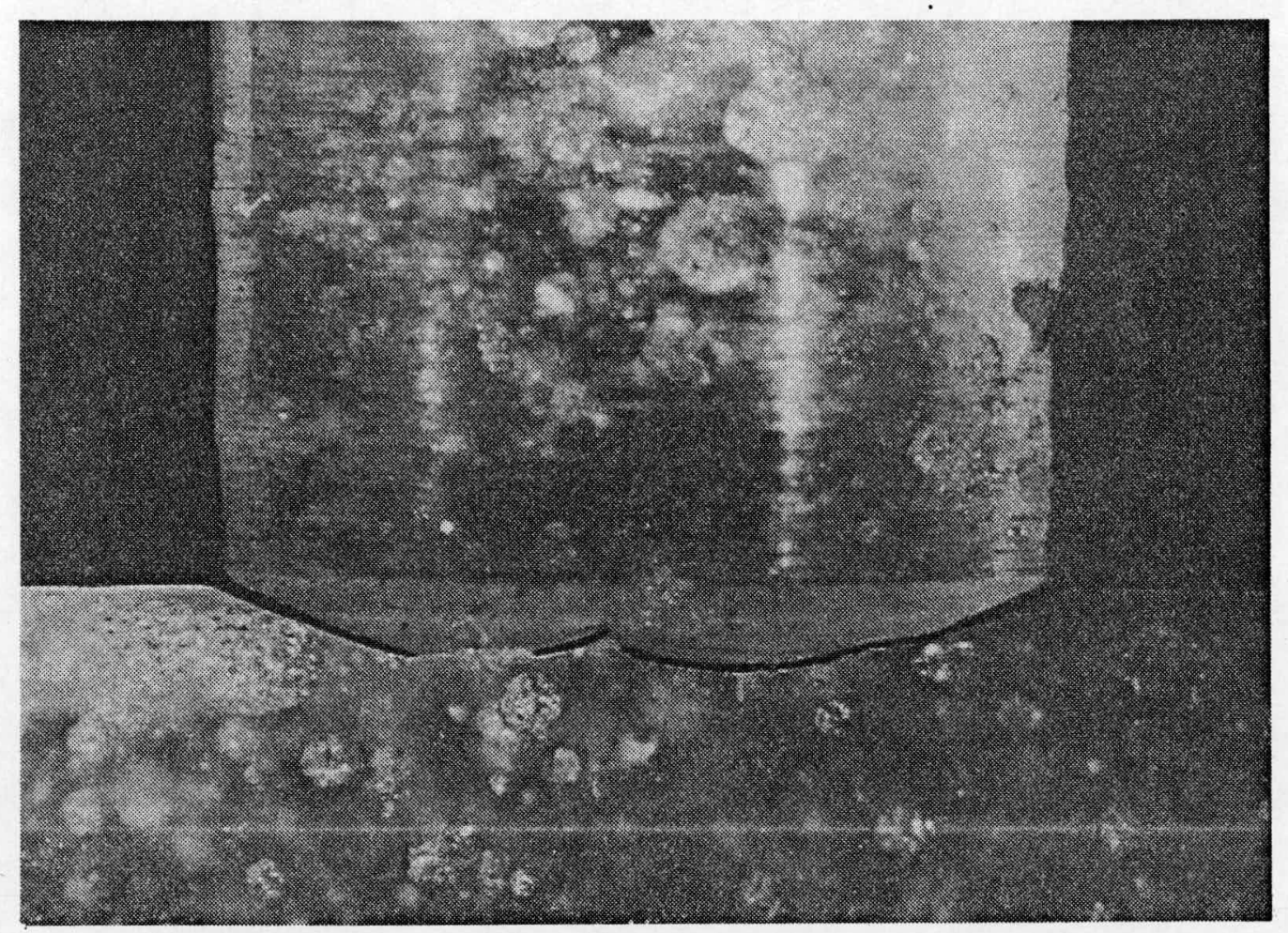

Figure 39. Tearing of Material Below Drill Point in 17-4PH (H900) Stainless Steel 


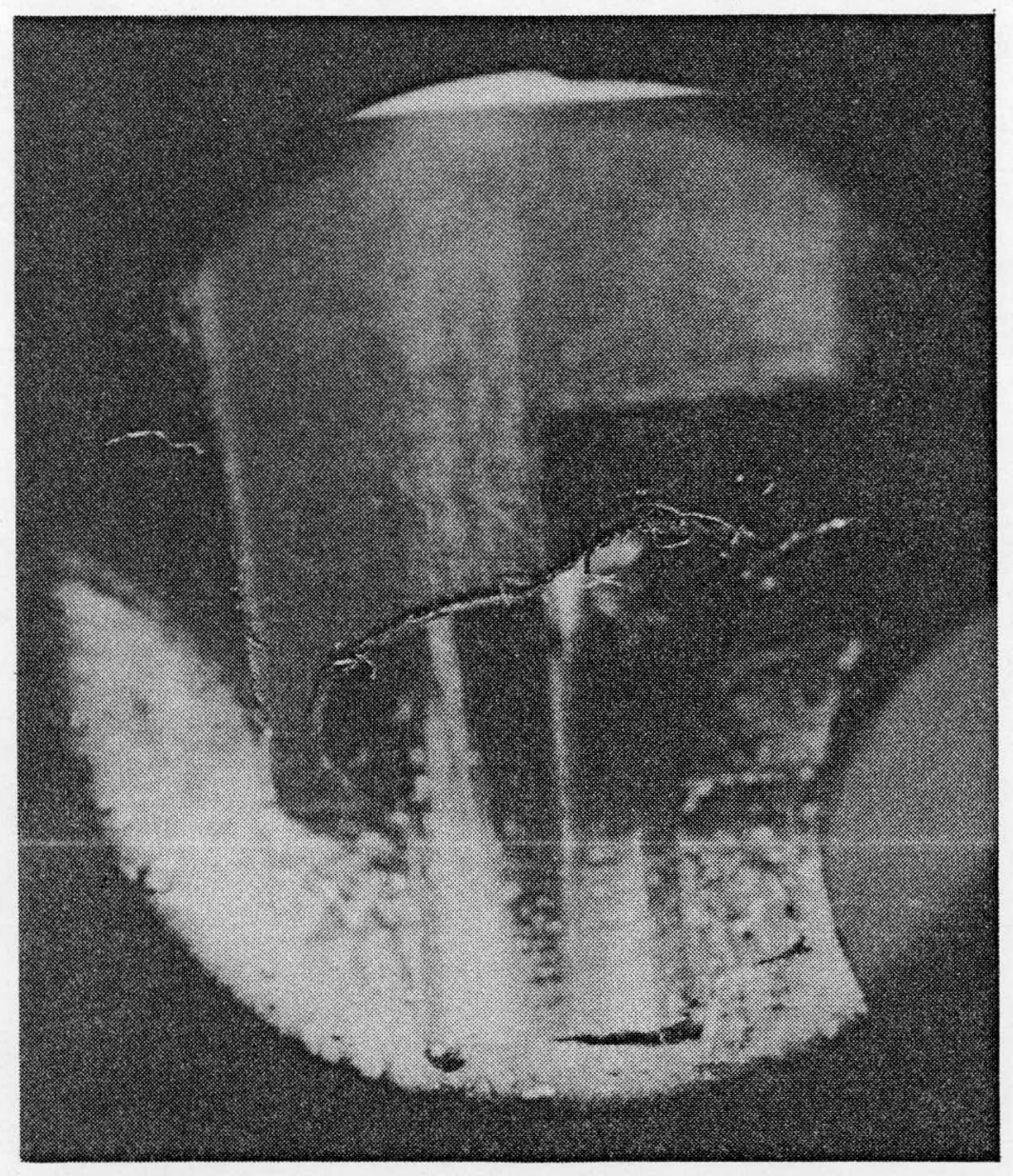

Figure 40. Short, Curled Drill-Exit Burr From 17-4PH (H900) Stainless Steel 


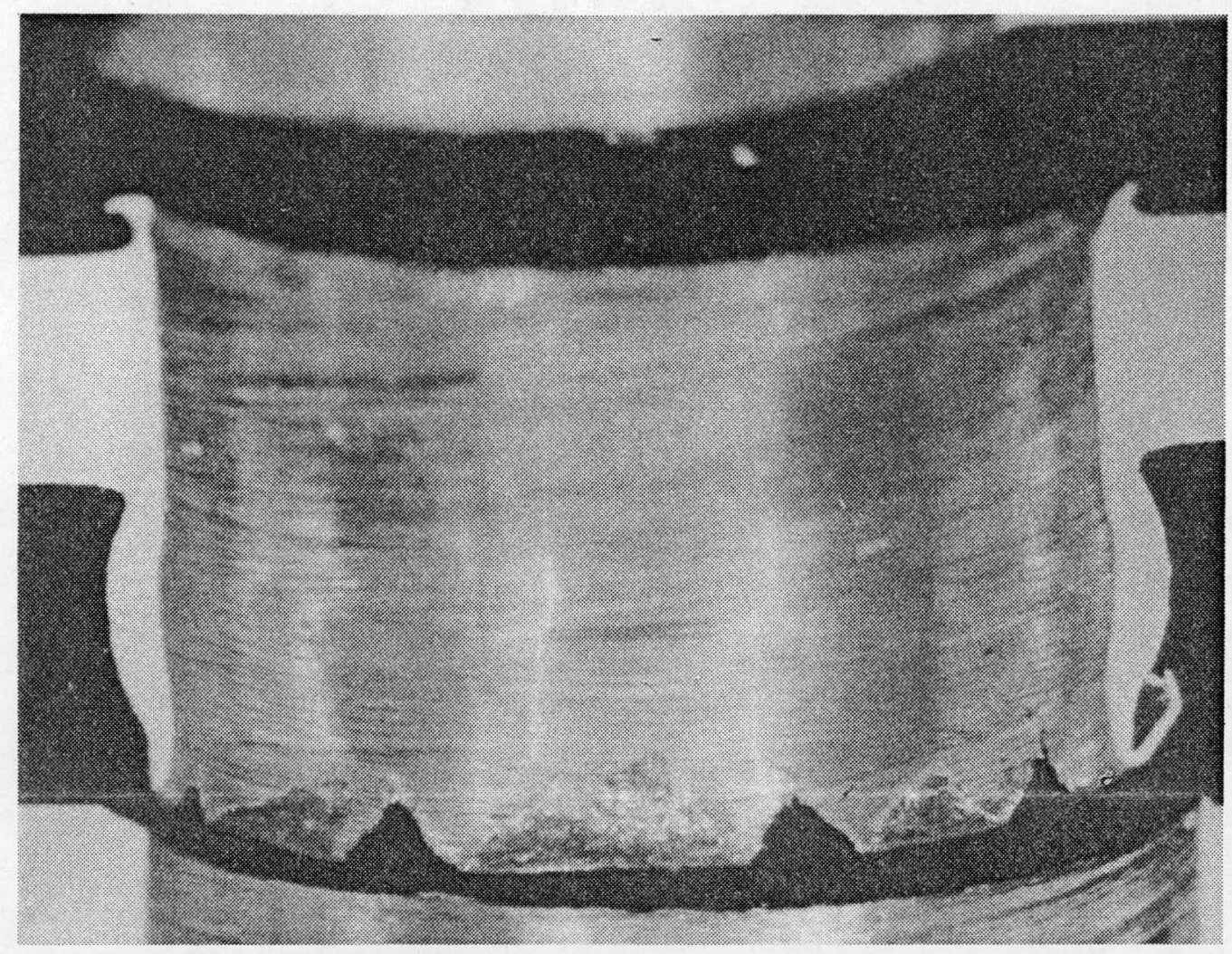

Figure 41. Cross Section of Long, Semiuniform Drill-Exit Burr From 6061-T6 Aluminum 


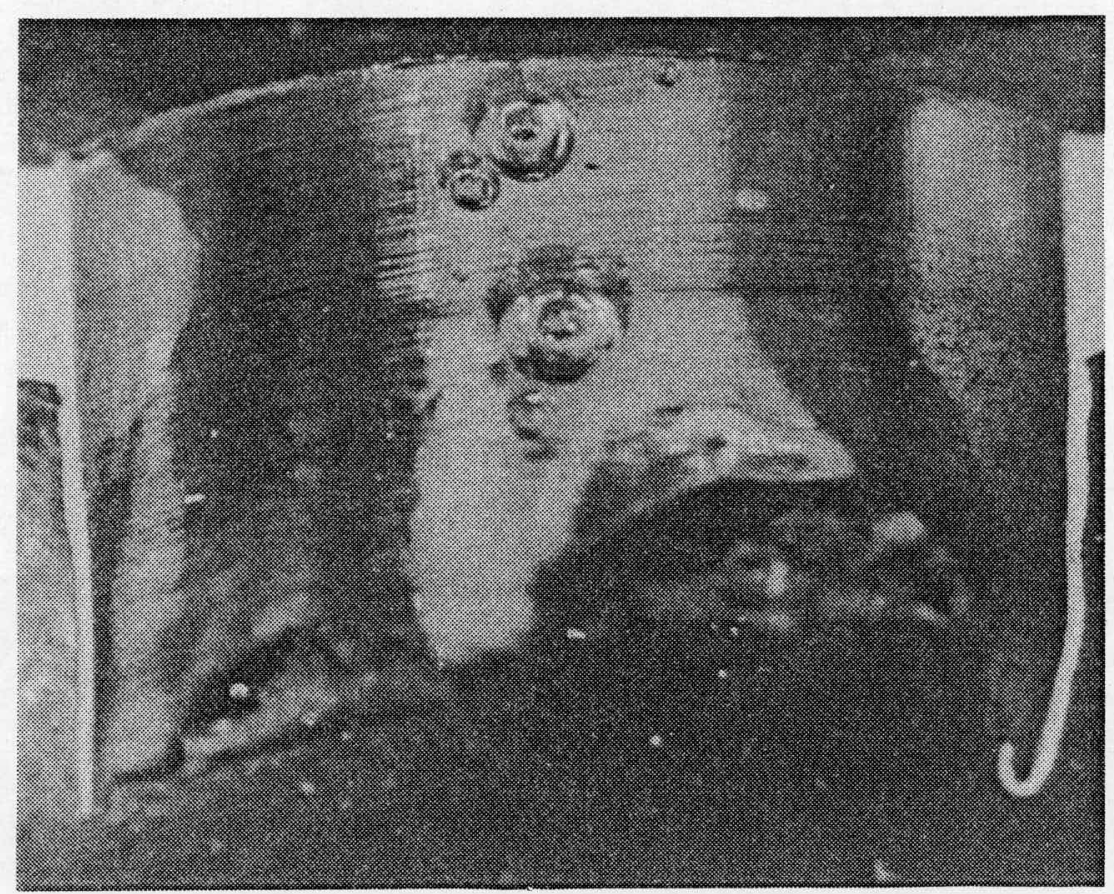

Figure 42. Cross Section of Long, Semiuniform Drill-Exit Burr From 1018 Steel 


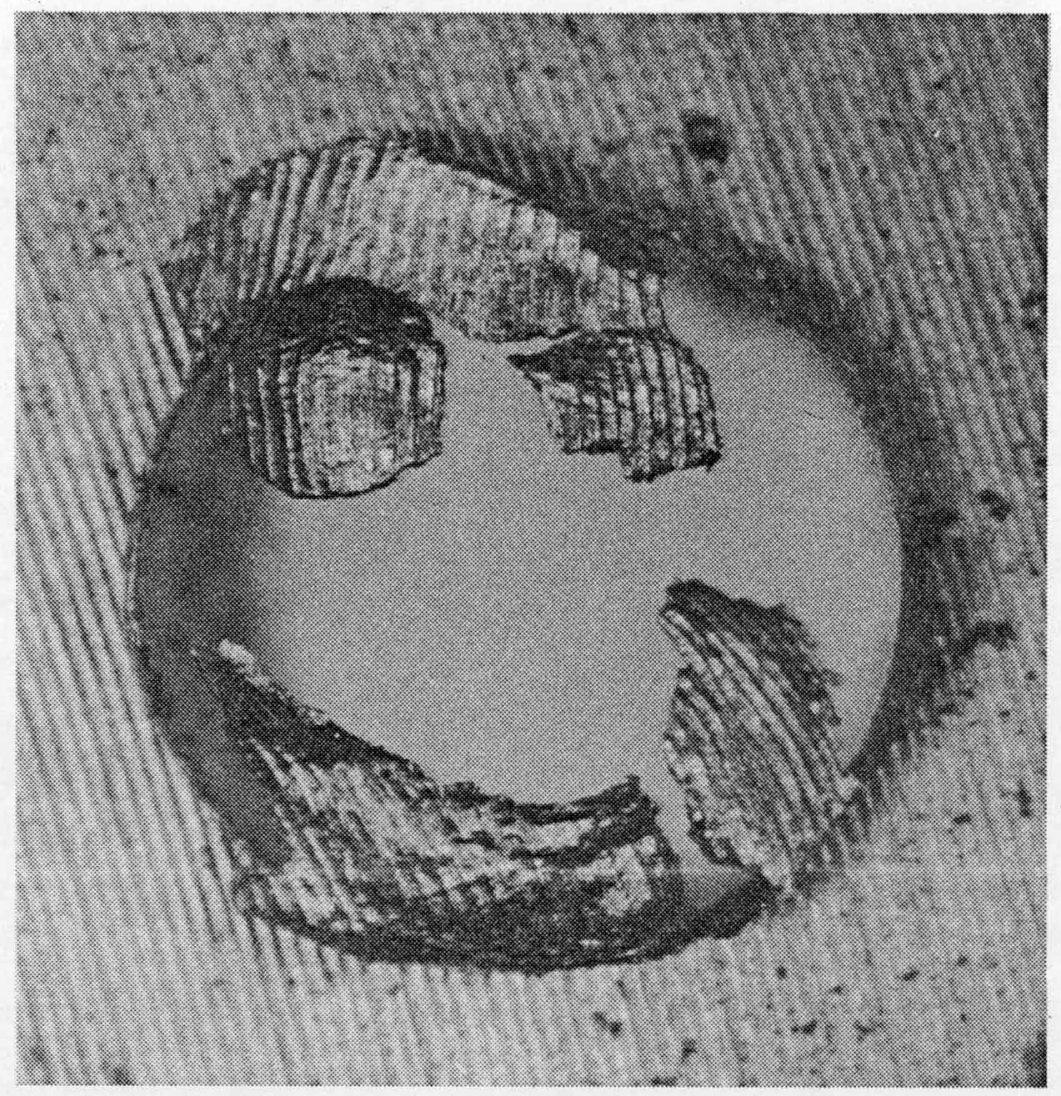

Figure 43. Ragged Dril1-Exit Burr From 1018 Steel 


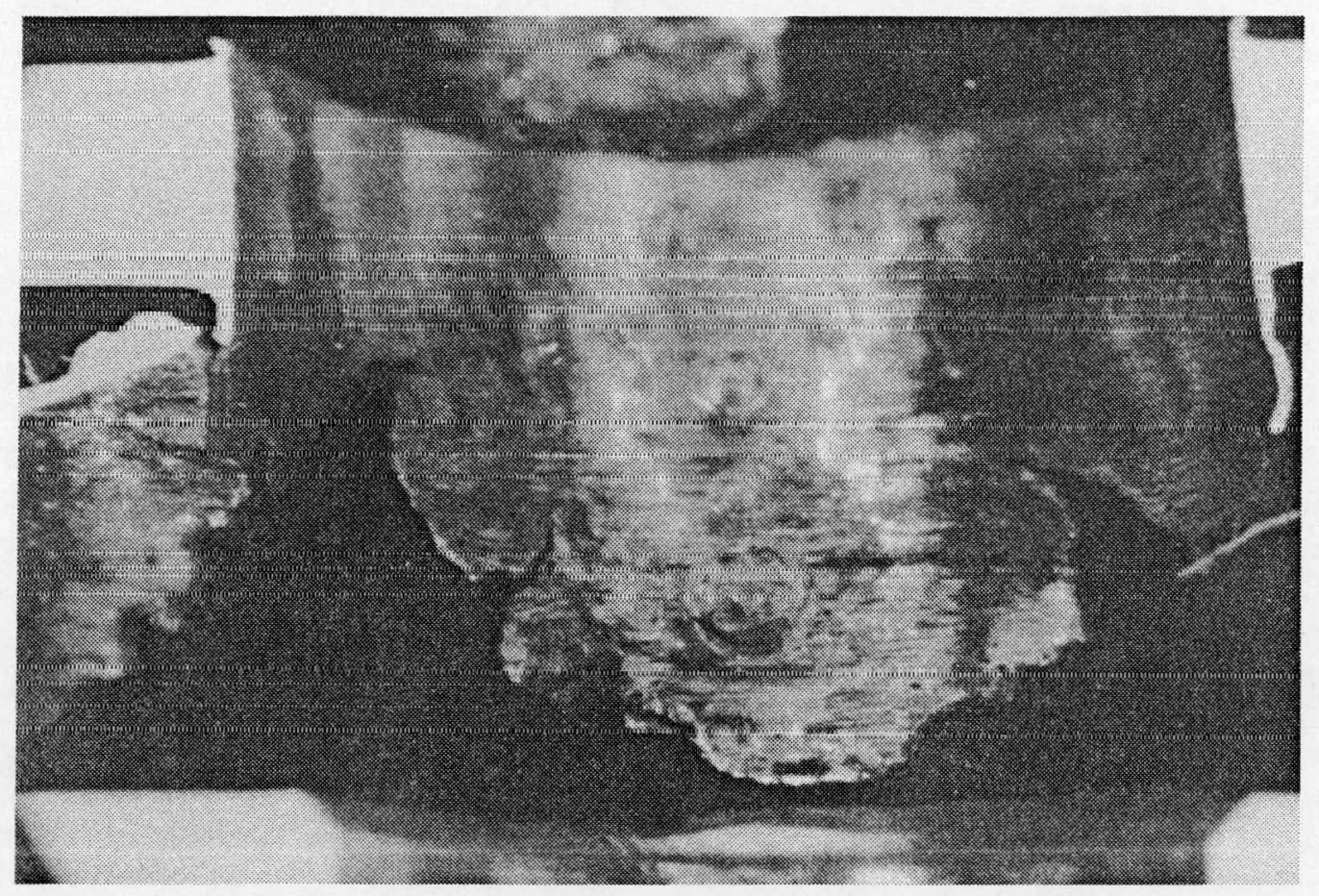

Figure 44. Cross Section of Ragged Drill-Exit Burr From 303Se Stainless Steel 


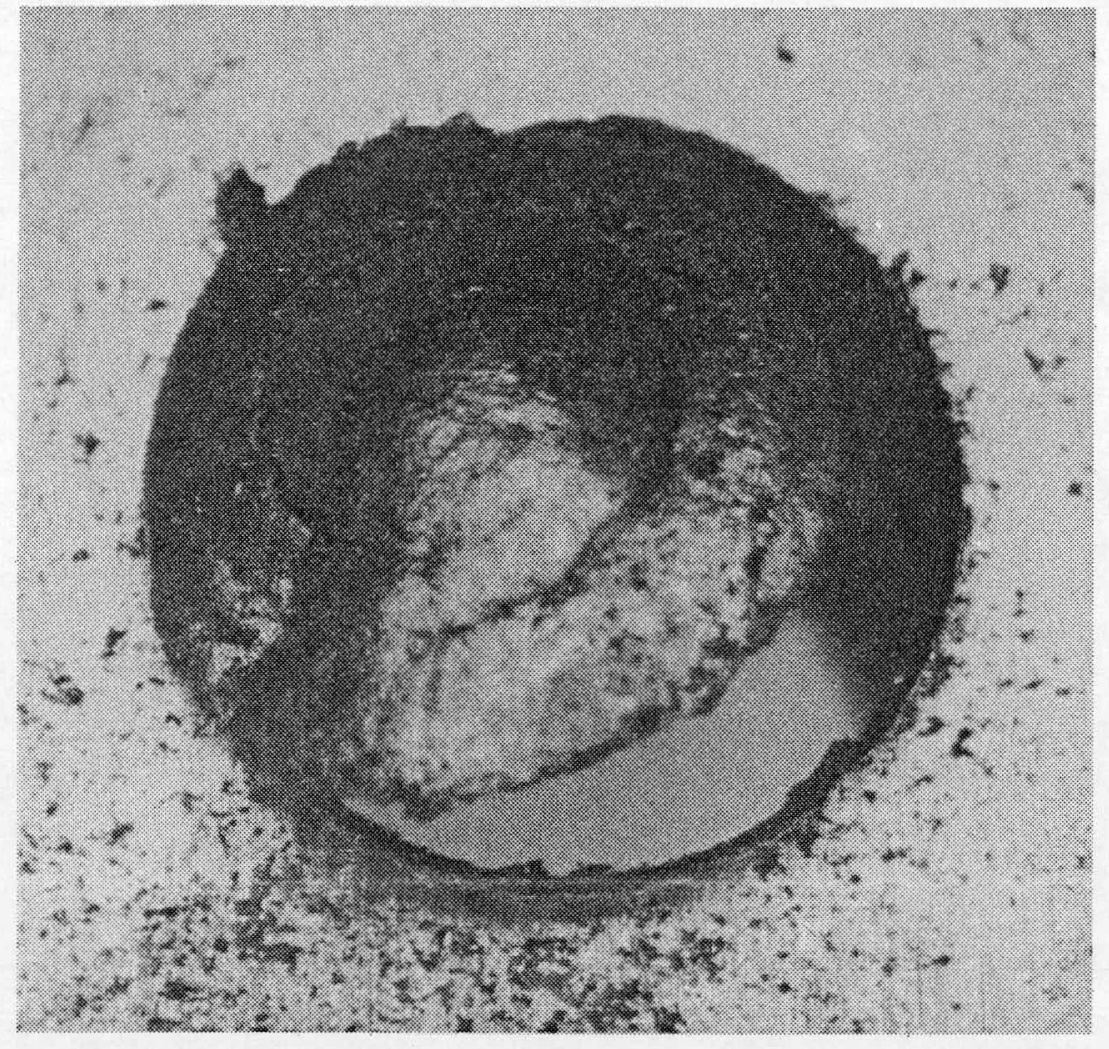

Figure 45. Cap of Metal Produced From 1018 Steel 


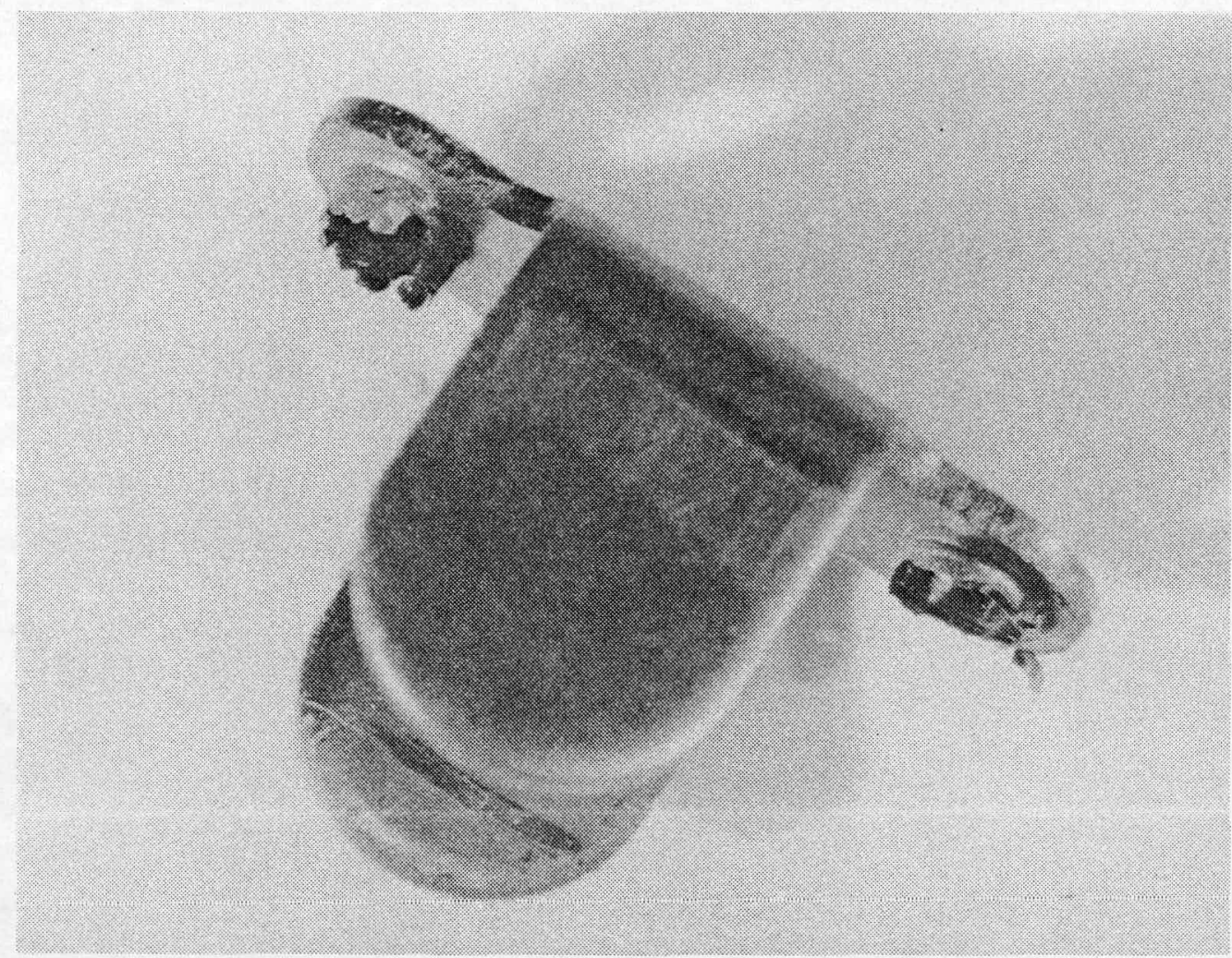

Figure 46. Consecutive Burrs From 302 Stainless Steel

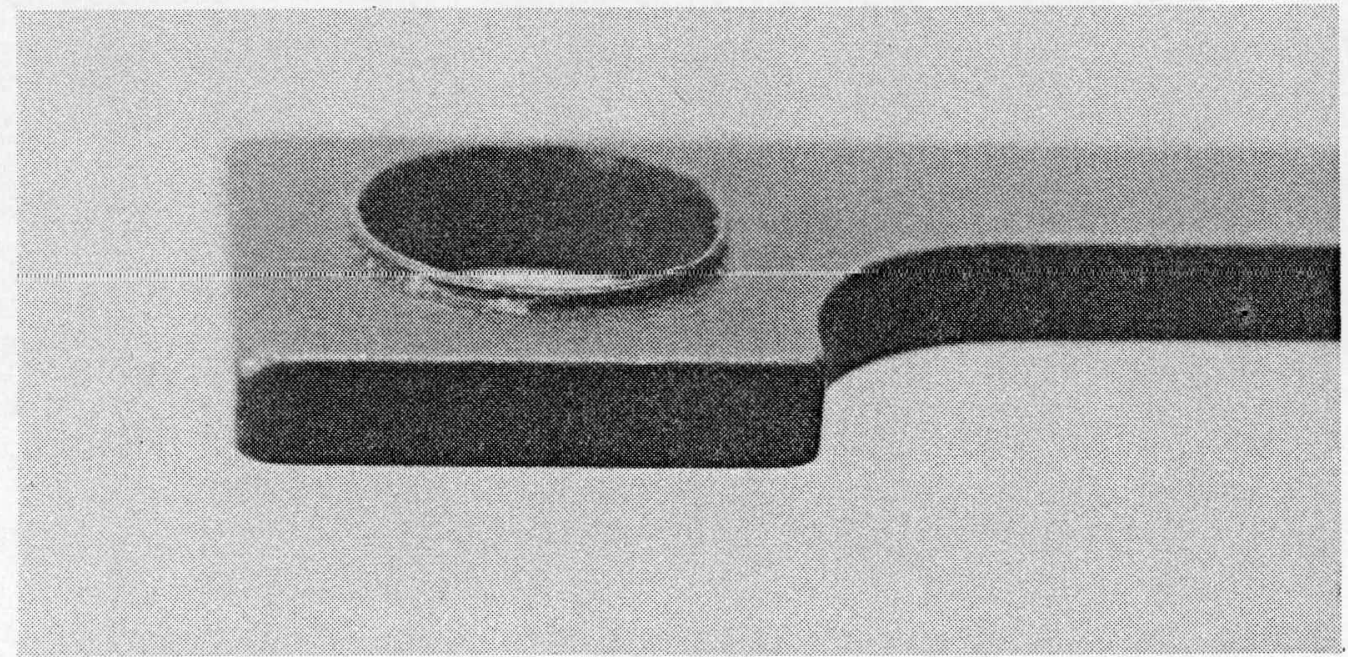

Figure 47. Extruded Burr Formed by Dull Drill in Beryllium-Copper 
Table 8. Effect of Drilling Variables on Entrance-Burr Thickness

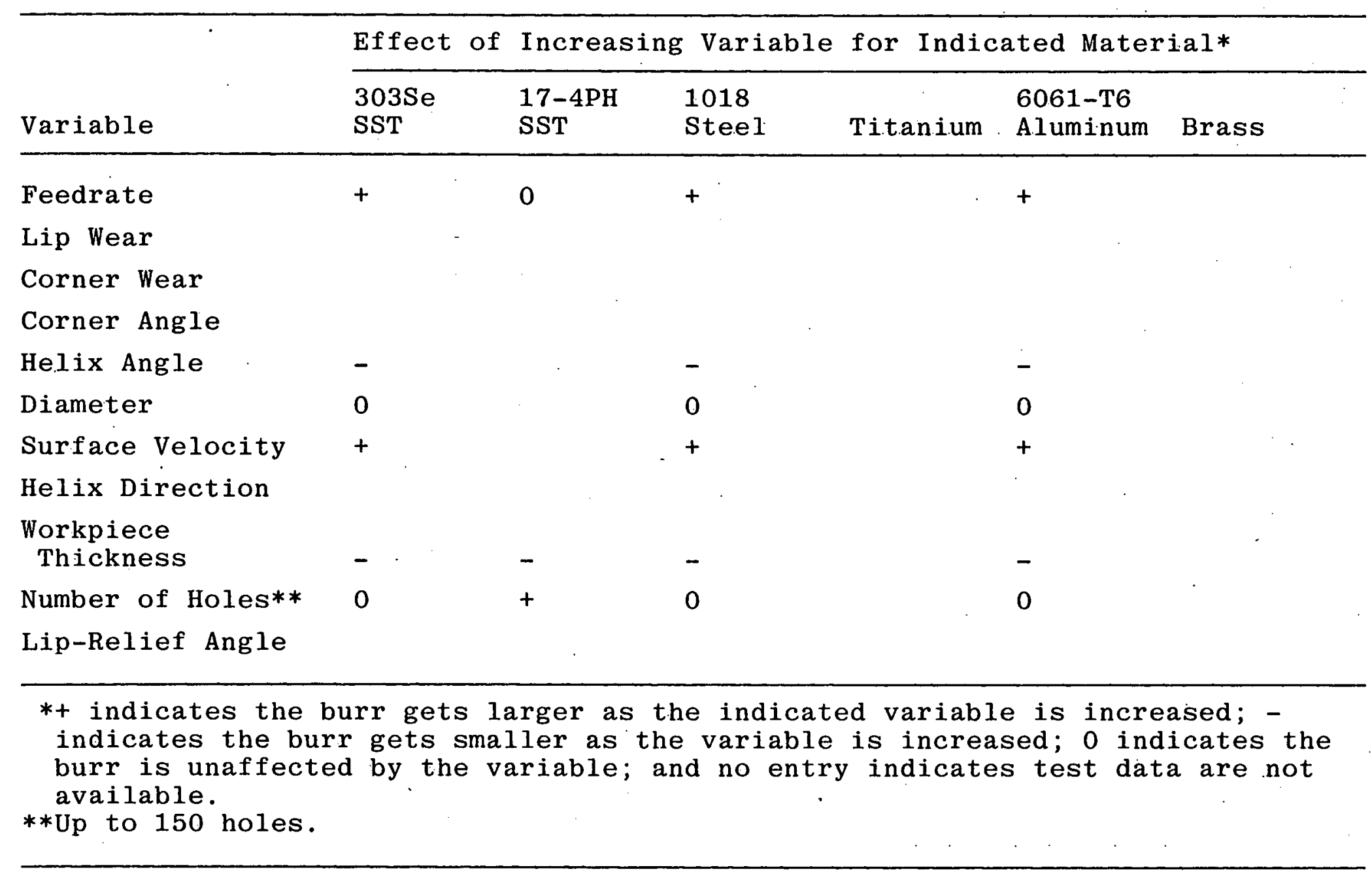


Table 9. Effect of Drilling Variables on Entrance-Burr Height

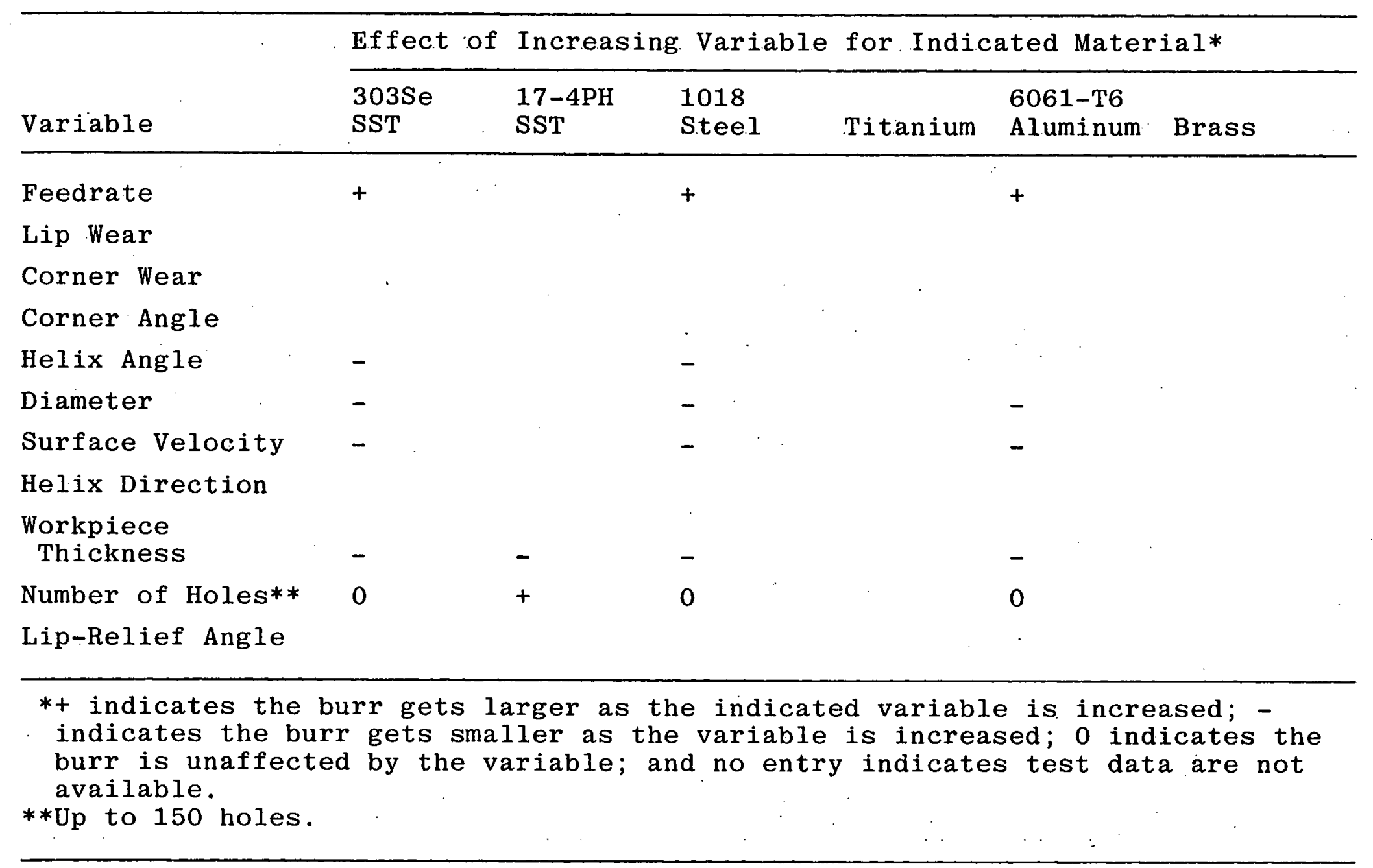


Table 10: Effect of Drilling Variables on Exit-Burr Thickness

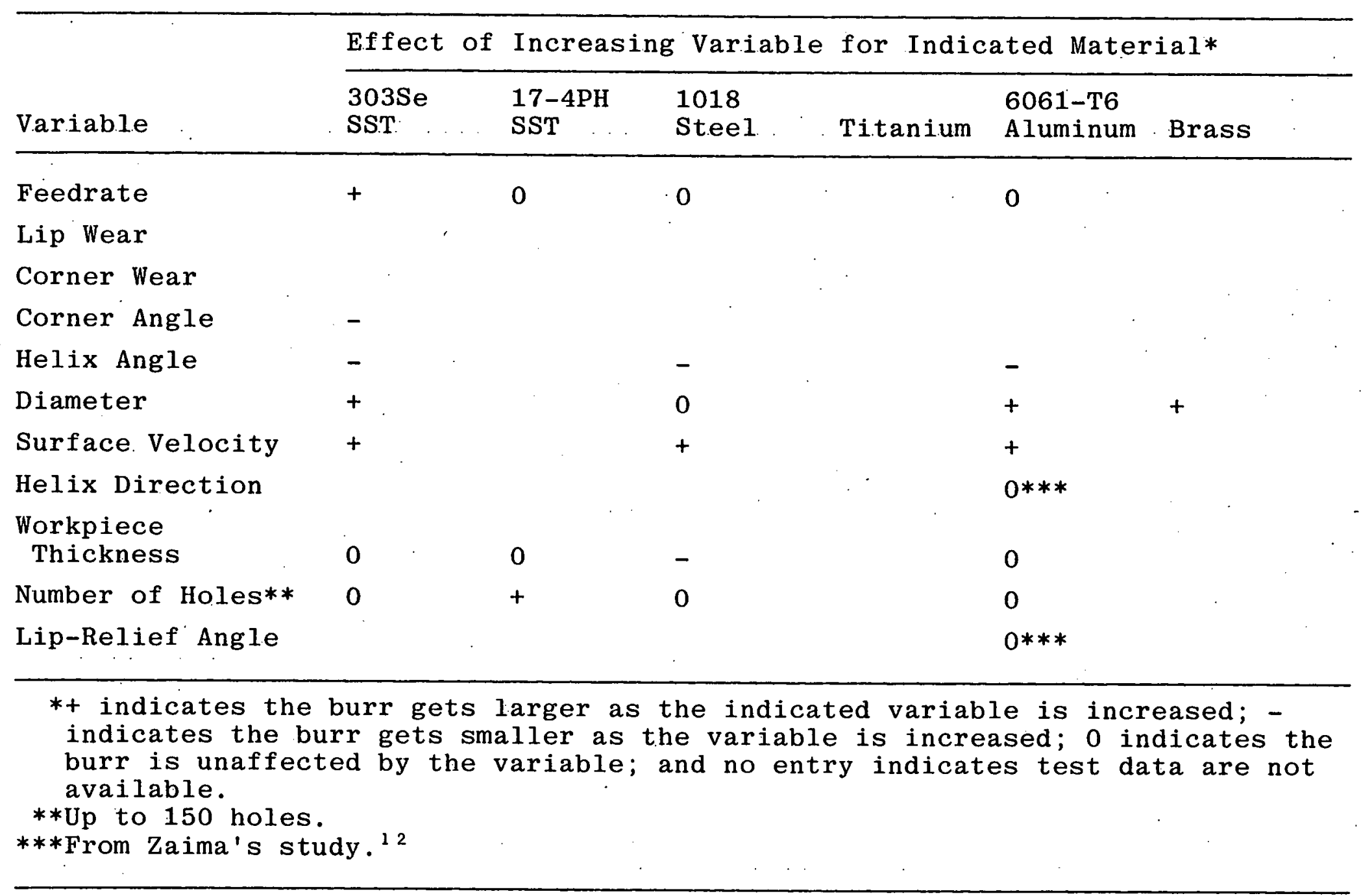


Table 11. Effect of Drilling Variables on Exit-Burr Height

\begin{tabular}{|c|c|c|c|c|c|c|c|}
\hline \multirow[b]{2}{*}{ Variable } & \multicolumn{7}{|c|}{ Effect of Increasing Variable for Indicated Material* } \\
\hline & $\begin{array}{l}303 \mathrm{Se} \\
\text { SST }\end{array}$ & $\begin{array}{l}17-4 \mathrm{PH} \\
\mathrm{SST}\end{array}$ & $\begin{array}{l}1018 \\
\text { S.tee.l }\end{array}$ & ' & Ti.tanium & $\begin{array}{l}6061-\mathrm{T} 6 \\
\text { Aluminum }\end{array}$ & Brass \\
\hline Feedrate & + & 0 & + & & & 0 & \\
\hline \multicolumn{8}{|l|}{ Lip Wear } \\
\hline Corner Wear & & & & & & & \\
\hline Corner Angle & + & & & & & & \\
\hline Helix Angle & - & & - & & & - & \\
\hline Diameter & + & & + & & & + & + \\
\hline Surface Velocityt & & & $:$ & & & $0 * * *$ & \\
\hline \multicolumn{8}{|l|}{ Helix Direction } \\
\hline \multicolumn{8}{|l|}{$\begin{array}{l}\text { Workpiece } \\
\text { Thickness }\end{array}$} \\
\hline $\begin{array}{l}\text { Number of Holes** } \\
\text { Lip-Relief Angle }\end{array}$ & 0 & + & & & $-t+$ & & 1 \\
\hline
\end{tabular}

*+ indicates the burr gets larger as the indicated variable. is increased; indicates the burr gets smaller as the variable is increased; 0 indicates the burr is unaffected by the variable; and no entry indicates test data are not available.

**Up to 150 holes.

***From Saito's study.15

tAssumes that surface velocity is maintained below the value recommended for the particular tool-workpiece combination. †tFrom Fleming's study.' 
Table 12. Recommended Variable Combinations to Minimize Exit-Burr Thickness

\begin{tabular}{|c|c|c|c|c|}
\hline \multirow[b]{2}{*}{ Workpiece Material } & \multicolumn{4}{|c|}{ Recommended Variable Combination*. } \\
\hline & Drill Point & $\begin{array}{l}\text { Feedrate } \\
\text { (IPR)**. }\end{array}$ & $\begin{array}{l}\text { Helix } \\
\text { Angle }\end{array}$ & $\begin{array}{l}\text { Surface } \\
\text { Velocity } \\
\text { (SFPM)*** }\end{array}$ \\
\hline 303Se Stainless Steel & Radial Lip & 0.0005 & $\mathrm{High}+$ & 50 \\
\hline 17-4PH Stainless Steel & Not Critical & 0.0005 to 0.0015 & High & \\
\hline 1018 Steel & Not Critical & 0.0005 to 0.0015 & $\mathrm{High}$ & 50 \\
\hline 6061-T6 Aluminum & Not Critical & 0.0005 to 0.0015 & High & 50 \\
\hline
\end{tabular}

*Based on drilling 150 holes, or less, and using feedrates and speeds compatible with the workpiece material.

$* * 0.001 \mathrm{ipr}=25.4 \mu \mathrm{m} / \mathrm{rev}$.

$* * * 100 \mathrm{sfpm}=510 \mathrm{~mm} / \mathrm{s}$. tA high helix angle implies 37-1/2 degrees; standard helix angles are 27-1/2
degrees. 

Table 13. Recommended Variable Combinations to Minimize Exit-Burr
Length

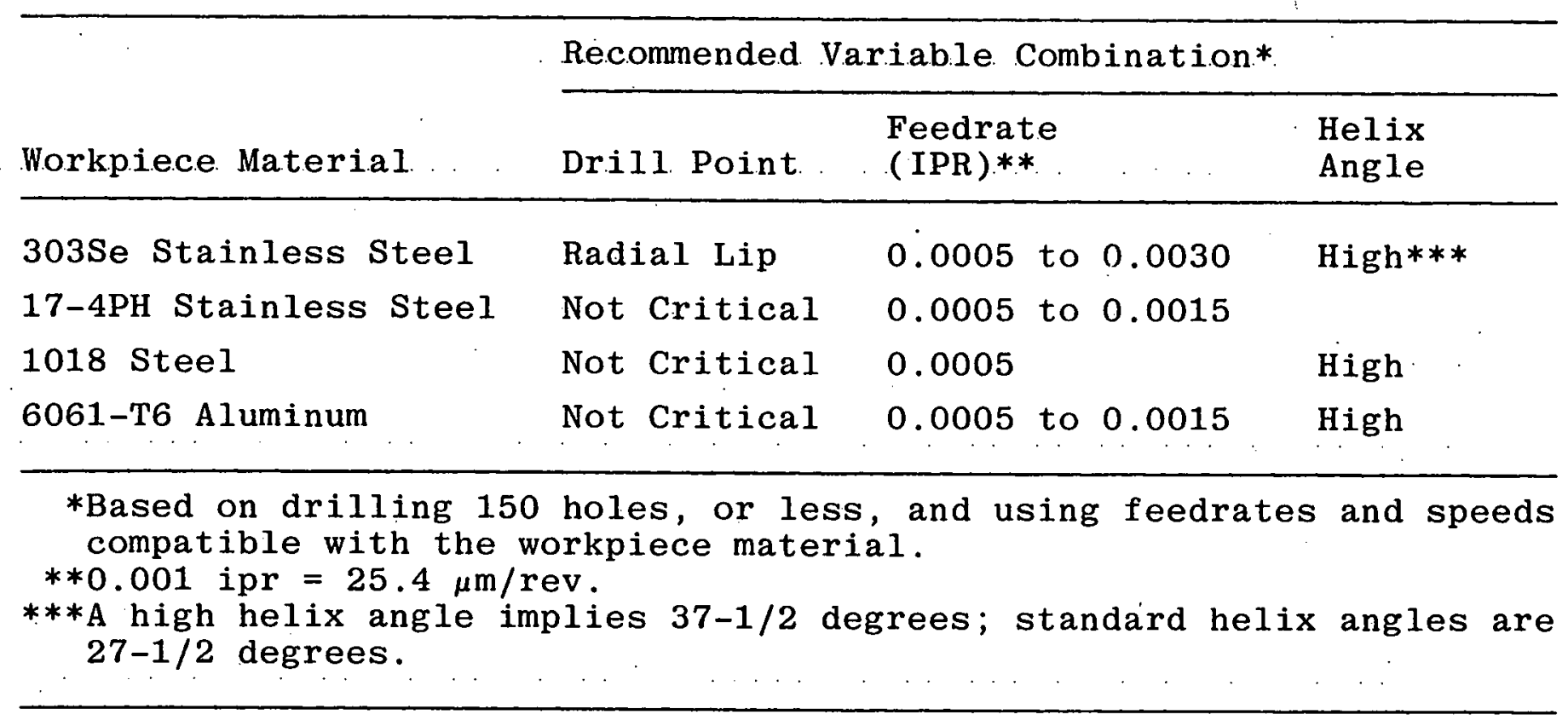


Table 14. Surface Velocities and Feedrates Recommended for Radial-Lip Drills by the Manufacturer

\begin{tabular}{|c|c|c|c|}
\hline Workpiece Material & $\begin{array}{l}\text { Surface } \\
\text { Velocity } \\
(\text { SFPM })^{*}\end{array}$ & $\begin{array}{l}\text { Feedrate } \\
(I P R) * *\end{array}$ & \\
\hline 303Se Stainless Steel & 60 or less & 0.003 to & 0.004 \\
\hline 17-4PH Stainless Steel & 30 or less & 0.001 to & 0.003 \\
\hline 1018 Steel & 70 or less & 0.003 to & 0.004 \\
\hline 6061-T6 Aluminum & 200 or less & 0.004 to & 0.008 \\
\hline $\begin{array}{c}* 100 \mathrm{sfpm}=510 \mathrm{~mm} / \mathrm{s} \\
* * 0.001 \mathrm{ipr}=25.4 \mu \mathrm{m} / \mathrm{r}\end{array}$ & & & \\
\hline
\end{tabular}




\section{REFERENCES}

${ }^{1}$ L. K. Gillespie, Burrs Produced by Drizling (Topical Report). UNCLASSIFIED. Bendix Kansas City: BDX-613-1248, December, 1975 .

${ }^{2}$ L. K. Gillespie, Vibratory Deburring (Final Report). UNCLASSIFIED. Bendix Kansas City: BDX-613-735 (Rev.), January, 1974 (Available from NTIS).

${ }^{3}$ L. K. Gillespie, The Formation and Properties of Machining Burrs. MS Thesis, Utah State University, Logan, Utah, 1973.

${ }^{4}$ L. K. Gillespie, The Effects of Reaming Variables on Burr Properties (Topical Report). UNCLASSIFIED. Bendix Kansas City: BDX613-1083 (Rev.), September, 1974 (Available from NTIS).

${ }^{5}$ L. K. Gillespie, Properties of Burrs Produced by Balz Broaching (Topical Report). UNCLASSIFIED. Bendix Kansas City: BDX-6131084 (Rev.), April, 1974 (Available from NTIS).

${ }^{6}$ L. K. Gillespie, Burrs Produced by End Mizling (Topical Report). UNCLASSIFIED. Bendix Kansas City: BDX-613-1503 (To be published).

${ }^{7}$ L. K. Gillespie, Burrs Produced by Side-Mizling Cutters (Topical Report). UNCLASSIFIED. Bendix Kansas City: BDX-613-1303 (Rev.), November, 1975 (Available from NTIS).

${ }^{8} \mathrm{~L}$. K. Gillespie, Burrs Produced by Grinding (Topical Report). UNCLASSIFIED. Bendix Kansas City: BDX-613-1372, February, 1976.

${ }^{9}$ L. K. Gillespie and P. T. Blotter, "The Formation and Properties of Machining Burrs," ASME Paper 75-PROD-J, 1975.

${ }^{10} \mathrm{~L}$. K. Gillespie, "The Effect of Cutting Edge Radius on Poisson Burr Properties," SME Paper.MR74-990, 1974.

${ }^{1}$ L. K. Gillespie, "The Formation and Properties of Burrs," SME Paper MRR75-03, April, 1975.

${ }^{12} \mathrm{~S}$. Zaima and others, "Drilling of Aluminum Alloy Plates With Special Type Point Drill," Journal of Japan Institute of Light Metals, Volume 18, Numbers 5 and 6, May and June, 1968, pp 269-276, 307-313.

${ }^{13}$ Clarence L. Bell and Blaine Kearsley, "The Effects of Drill Point Geometry, Feed and speed on Cutting Forces and Burrs," unpublished report for Department of Manufacturing Engineering, Utah State University, Logan, Utah, 1963. 
${ }^{14} \mathrm{C}$. M. Fleming, Precision Hole Generation Methods, McDonnell Aircraft Company: AFML-TR-73-135, March, 1973.

${ }^{15}$ Yuzo Saito and others, "Drilling Machinability for Aluminum Sheets,"Journal of Japan Institute of Light Metals (KEI Kinzoku), Volume 20, Number 2, February, 1970, pp 69-76.

${ }^{16}$ Shigeo Zaima and others, "On the Effect of Cutting Fluid on Drilling Aluminum Alloy," Journal of Japan Institute of Light Metals (KEI Kinzoku), Volume 19, Number 1, January, 1969; p 8.

${ }^{17} \mathrm{Y}$. Hasegawa and others, "Burr in Drilling Aluminum and a Prevention of It," SME Paper MR75-480, April, 1975.

${ }^{18} \mathrm{Joseph}$ L. Phillips, MuZti-Layer Fastener Systems, Boeing Commercial Airplane Company: Report IR-752-4 (III), January, 1975 .

19 Joseph L. Phillips, MuZti-Layer Fastener Systems, Boeing Commercial Airplane Company: Report IR-752-4 (V), July, 1975.

$2{ }^{\circ}$ Otto Kienzle and D. Werner Kienzle, Tool wear in the Cutting of Thin-Gauge Steel Sheets. ASTME Research Report Number 22, May 1, 1959. Translation and discussion of article in Stahl und Eisen, Volume 78, Number.12, June 12, 1958, pp 820-828.

'John E. Biegel and Robert E. Holmes, Development of a Punchability Rating Method for Electrical Steels. ASTME Research Report Number 30, March 1, 1961.

${ }^{2}$ Hans Buhler and Fedor Pollmar, "The Formation of Burrs in the Cutting of Thin Sheet," Bander-Bleche-Rohre, Volume 12 , Number 3 ,
March, 1971, pp 105-111.

$2{ }^{3}$ Harding R. Hugo, "How to Improve Metal Stamping Die Performance," Sheet Metal Industries, February, 1971, pp 120-135.

$2{ }^{4}$ Frederico Strasser, "How Control of Burrs Aids Sheet Metal Stamping," The Iron Age. Volume 185, Number 3, January 21, 1960,

${ }^{25} \mathrm{~K}$. K. Wang and others, An Anazysis of Punching Variables by Two-Level Fractional Factorial Design. ASME Paper 69-WA/Prod 27, ${ }^{26} \mathrm{C}$. S. Wukusik and R. S. Zeno, "Improving Punchability of Silicon Steel," Tool Engineer. Volume 41, Number 12, December, 1958,
pp 63-70. 
27 James Nielson McBride, The Magnitude of Burrs Caused by Electrical Discharge Machining. MS thesis, Utah State University, Logan, Utah, 1969.

${ }^{28} \mathrm{~L}$. K. Gillespie, "Effects of Measurement Technique and Experimental Design in the Analysis of Burrs," SME Paper MR75-985, 1975.

29 Joseph L. Phillips, MuZti-Layer Fastener Systems, Boeing Commercial Airplane Company: Report IR-752-4 (IV), April, 1975 .

${ }^{30}$ Akiyasum Yuki, "A Study on Burr in Drilling," The Research Bulletin of the Facility of Education, Natural Science Division, Oita University, Volume 3, Number 3, October, 1968.

${ }^{3} \mathrm{M}$. Okoshi and others, Journal Japan Society of Precision Engineering, Volume 11, Number 9, 1945, pp 25-38.

${ }^{32}$ Anthony Safronas, The Formation and Control of Drizling Burrs, Doctoral Dissertation, University of Detroit, Detroit, Michigan, 1975.

${ }^{3}{ }^{3}$ Anthony Safronas and others, "Reduction of Burr Formation in Drilling," SME Paper MR75-376, 1975. 
Appendix

TABULAR DATA ON BURRS OBTAINED FROM

STUDY OF DRILLING VARIABLES 
Table A-1. Effects of Dri11 Geometry on Burr Size

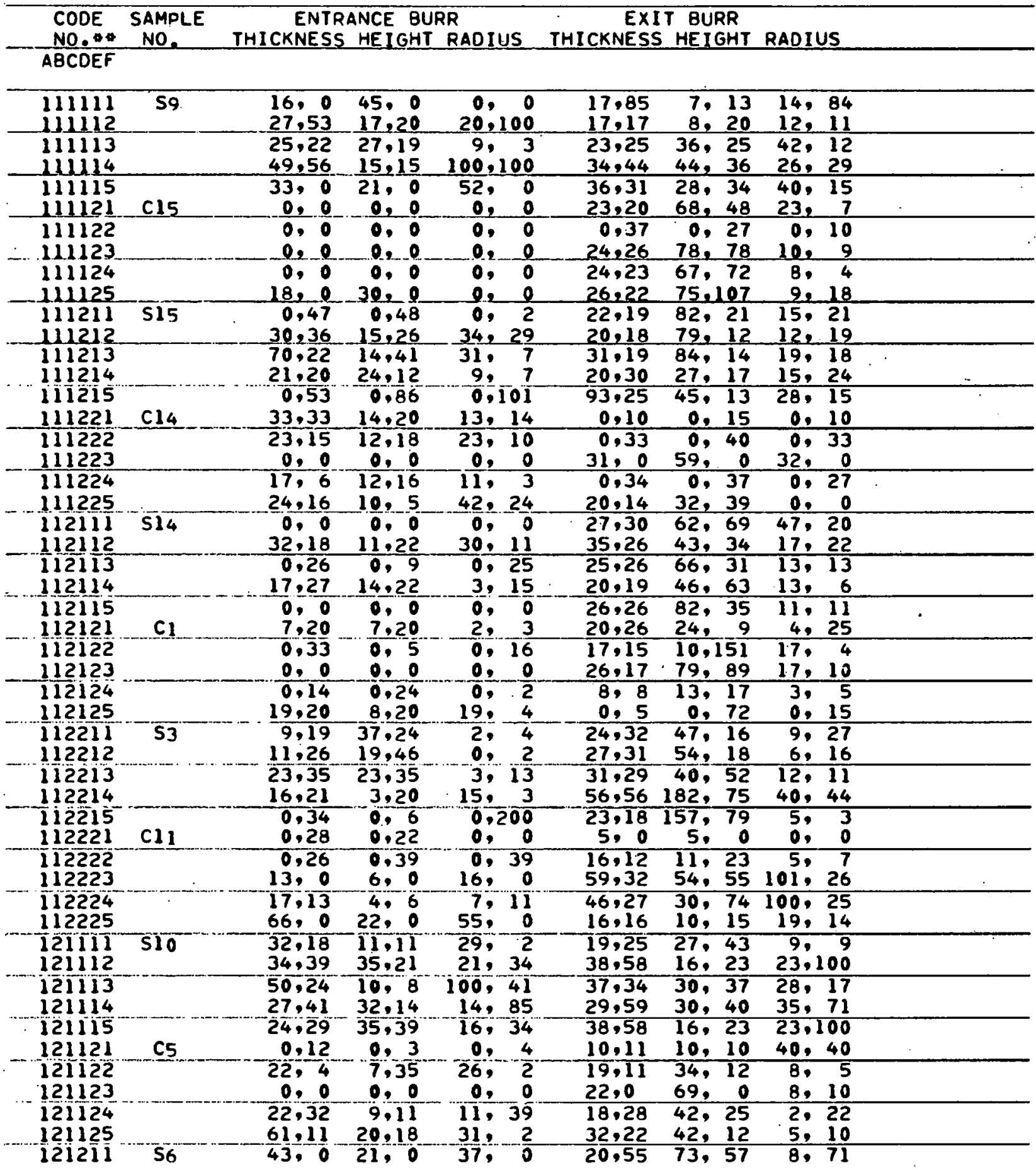

- VALUES SHOWN ARE IN 0.0001 INCH UNITS 0.0001 INCH EQUALS 2.54 MICROMETERS. $\triangle \triangle$ CODE NUMRERS ARE IOENTIFIED IN TABLE I IN THE MAIN BOOY OF THIS REPORT. 
Table A-1 Continued. Effects of Drill Geometry on Burr Size

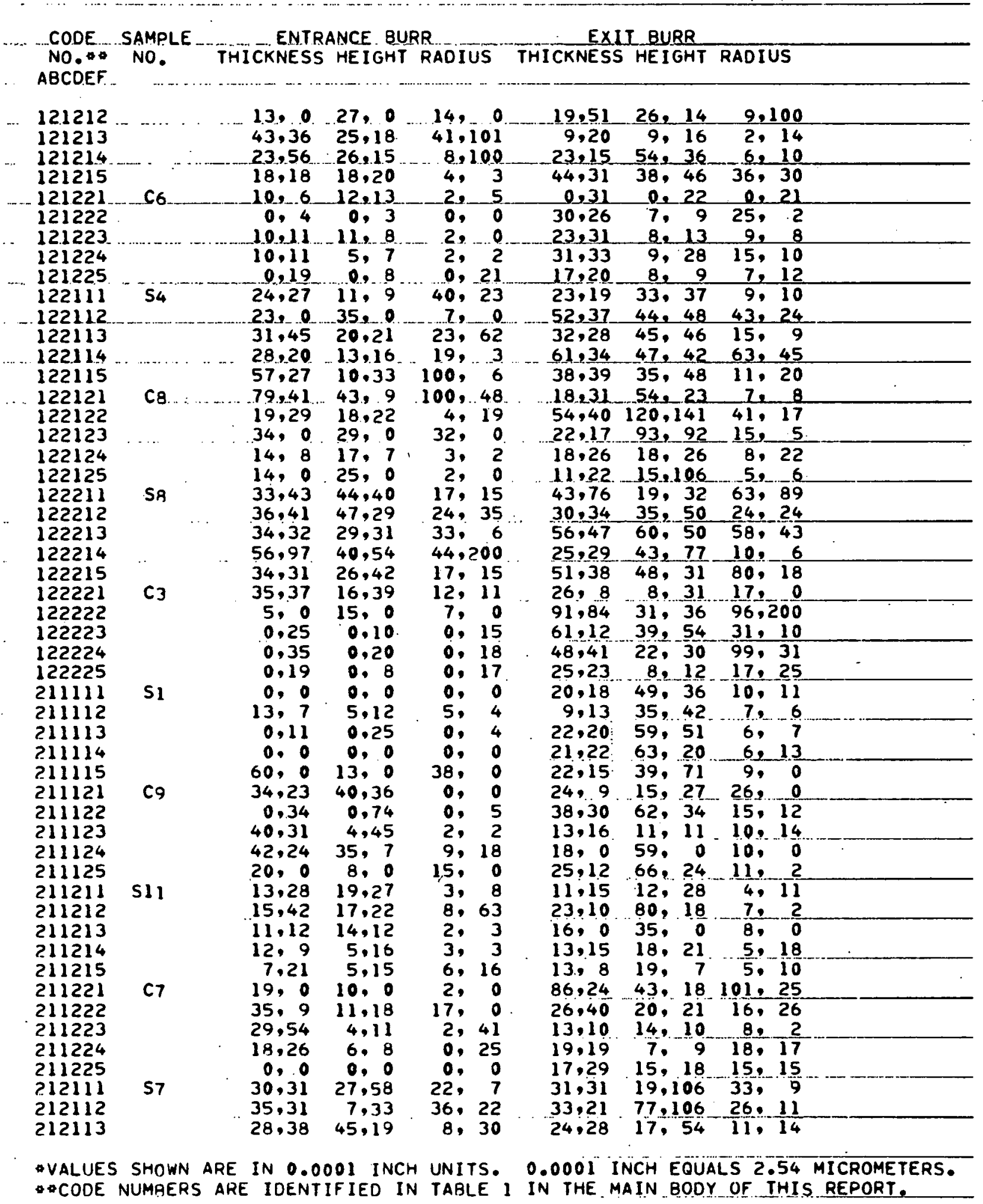


Table A-1 Continued. Effects of Drill Geometry on Burr Size

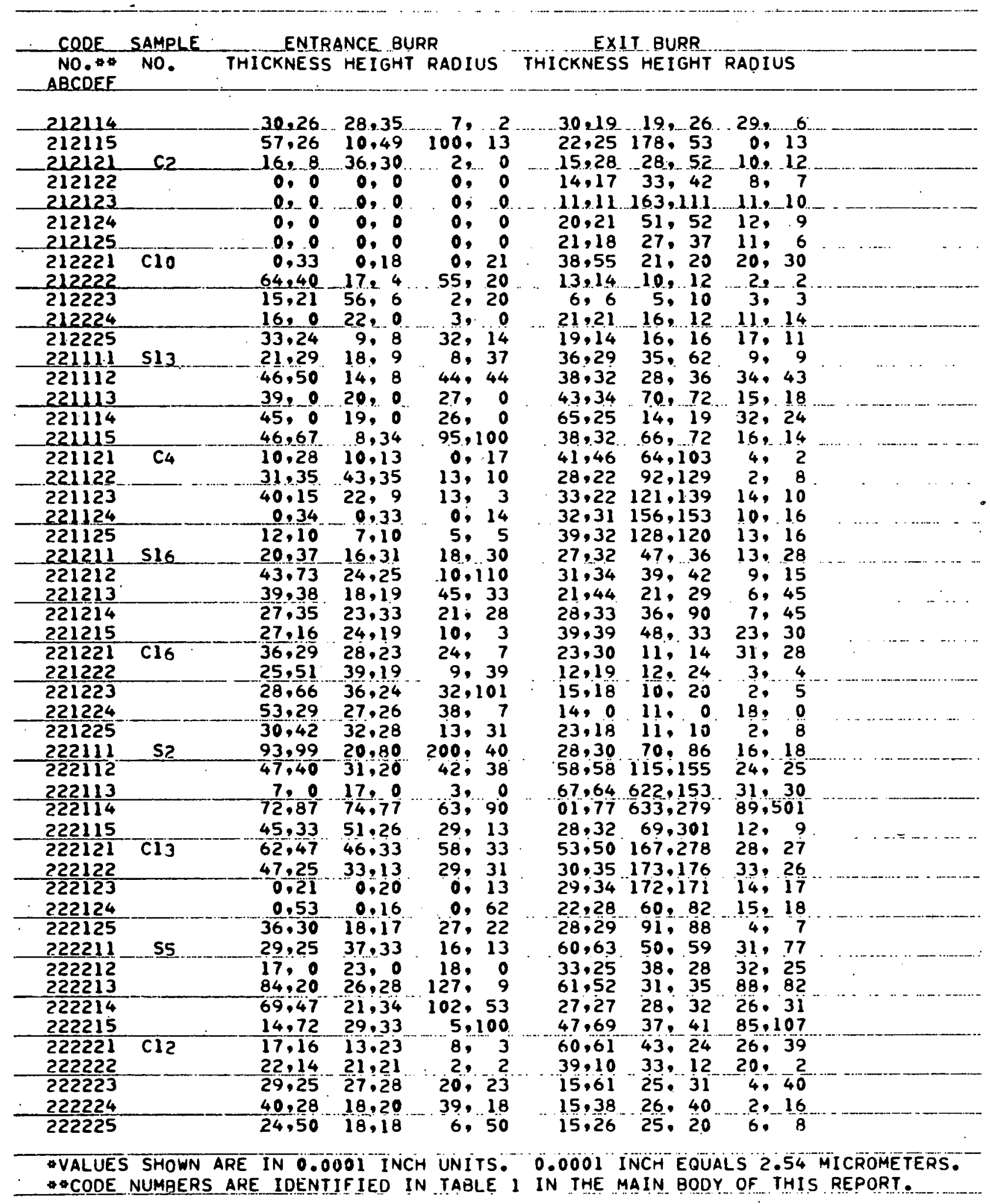


Table A-1 Continued. Effects of Drill Geometry on Burr Size

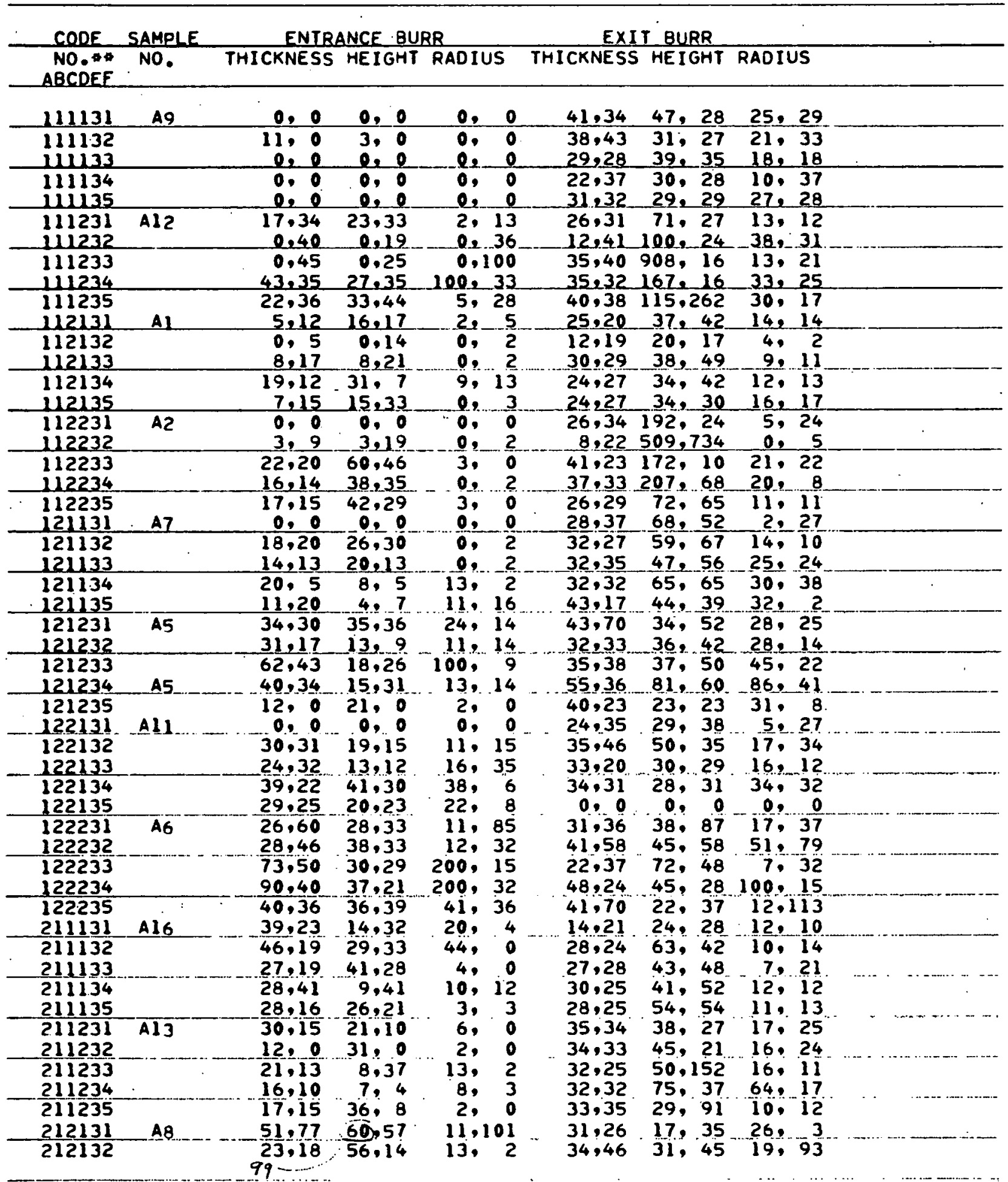

-VALUES SHOWN ARE IN O.0001 INCH UNITS. 0.0001 INCH EQUALS $2.5 \%$ MICROMETERS. - COODE NUMBERS ARE IDENTIFIEQ IN TABLE I IN THE MAIN BODY OF THIS REPORT. 
Table A-1 Continued. Effects of Drill Geometry on Burr Size

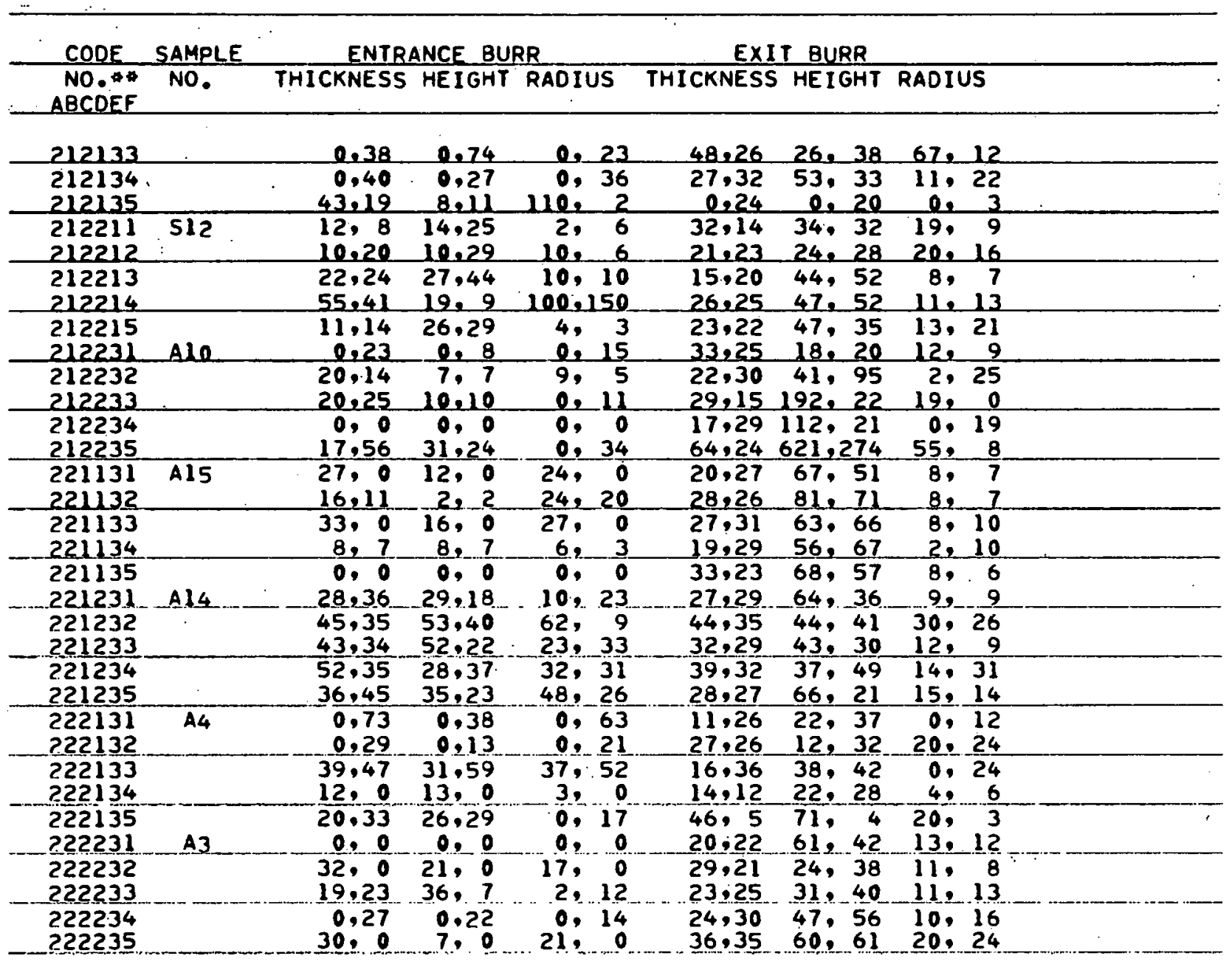

- VALUES SHOWN ARE IN 0.0001 INCH UNITS. 0.0001 INCH EQUALS 2.54 MICROMETERS. * CODE NUMAERS ARE IDENTIF IED IN TABLE I IN THE MAIN BODY OF THIS REPORT. 
Table A-2. Effects of Subland Drills on Burr Size

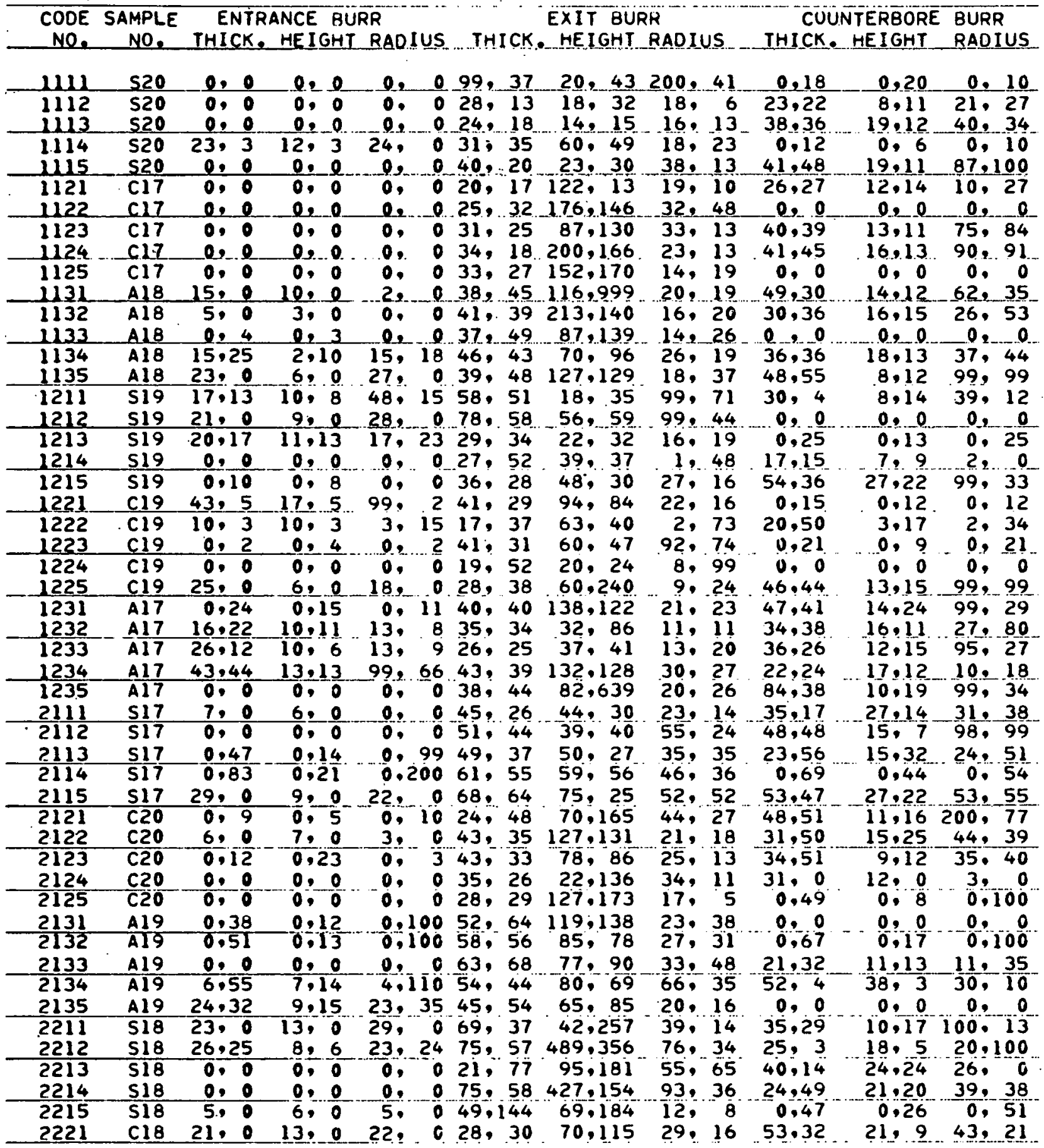

-VALUES SHOWN ARE IN 0.0001 INCH UNITS. 0.0001 INCH EQUALS 2.54 MICROMETERS. CODE NUMBERS ARE IOENTIFIED IN TABLE 5 IN THE MAIN BODY OF THIS REPORT. 
Table A-2 Continued. Effects of Subland Drills on Burr Size

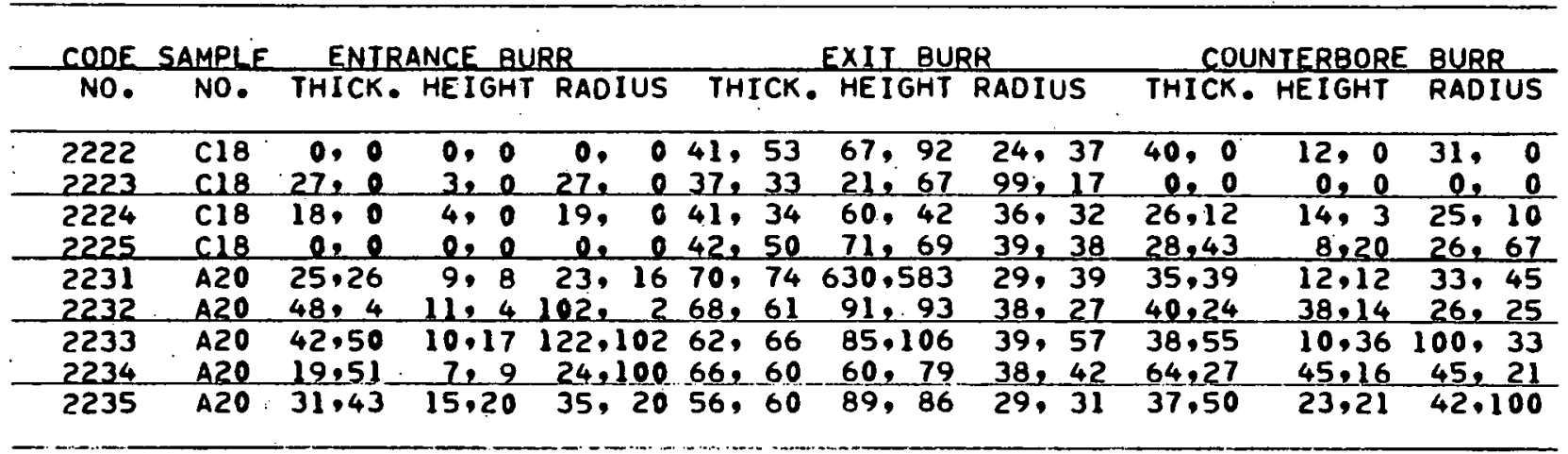

QVALUES SHOWN ARE IN 0.0001 INCH UNITS. 0.0001 INCH EQUALS 2.54 MICROMETERS. CODE NUMBERS ARE IDENTIFIED IN TABLE 5 IN THE MAIN BODY OF THIS REPORT. 
Table A-3. Effect of Tool Wear on Burr Properties

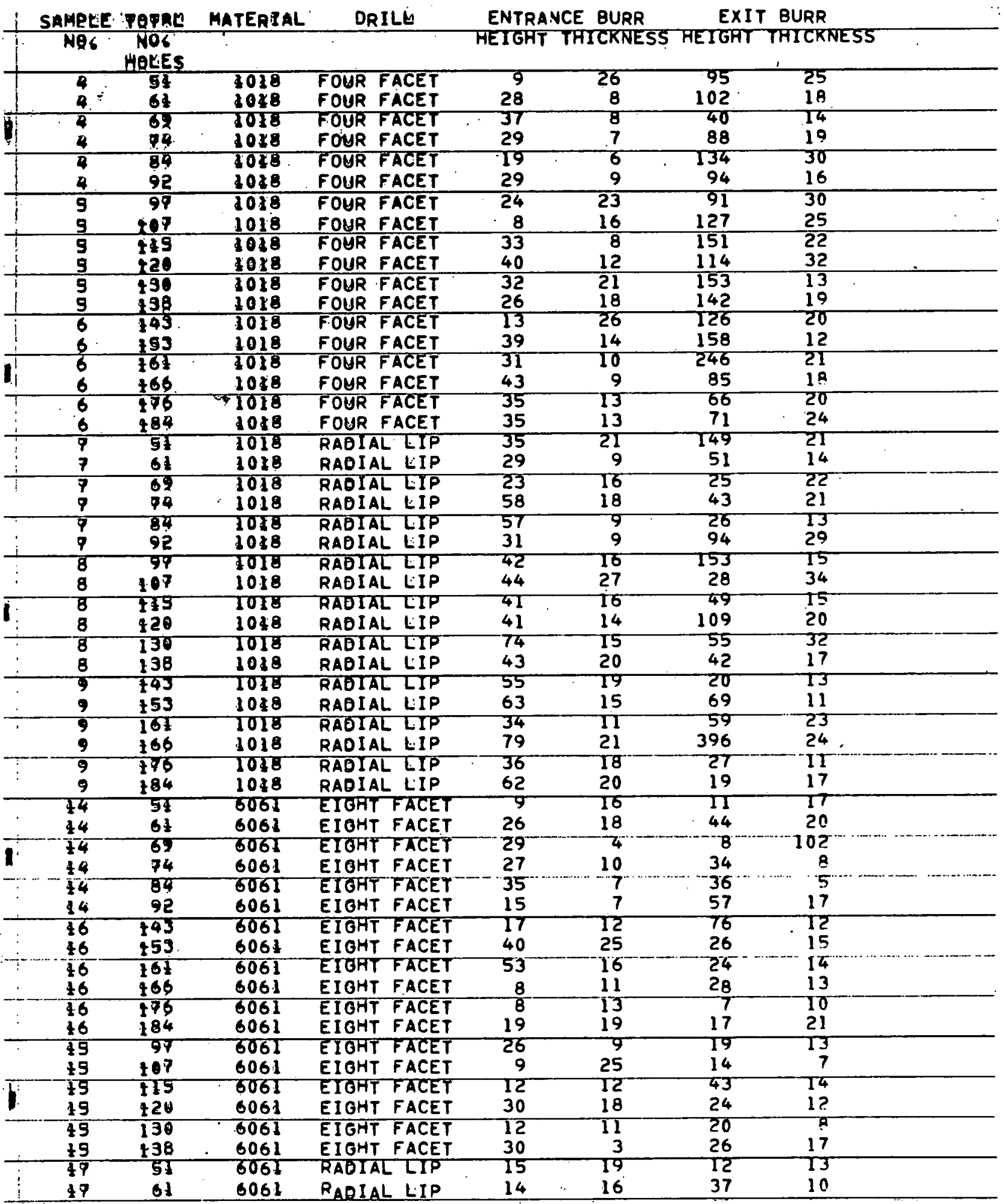


Table A-3 Continued. Effect of Tool Wear on Burr Properties

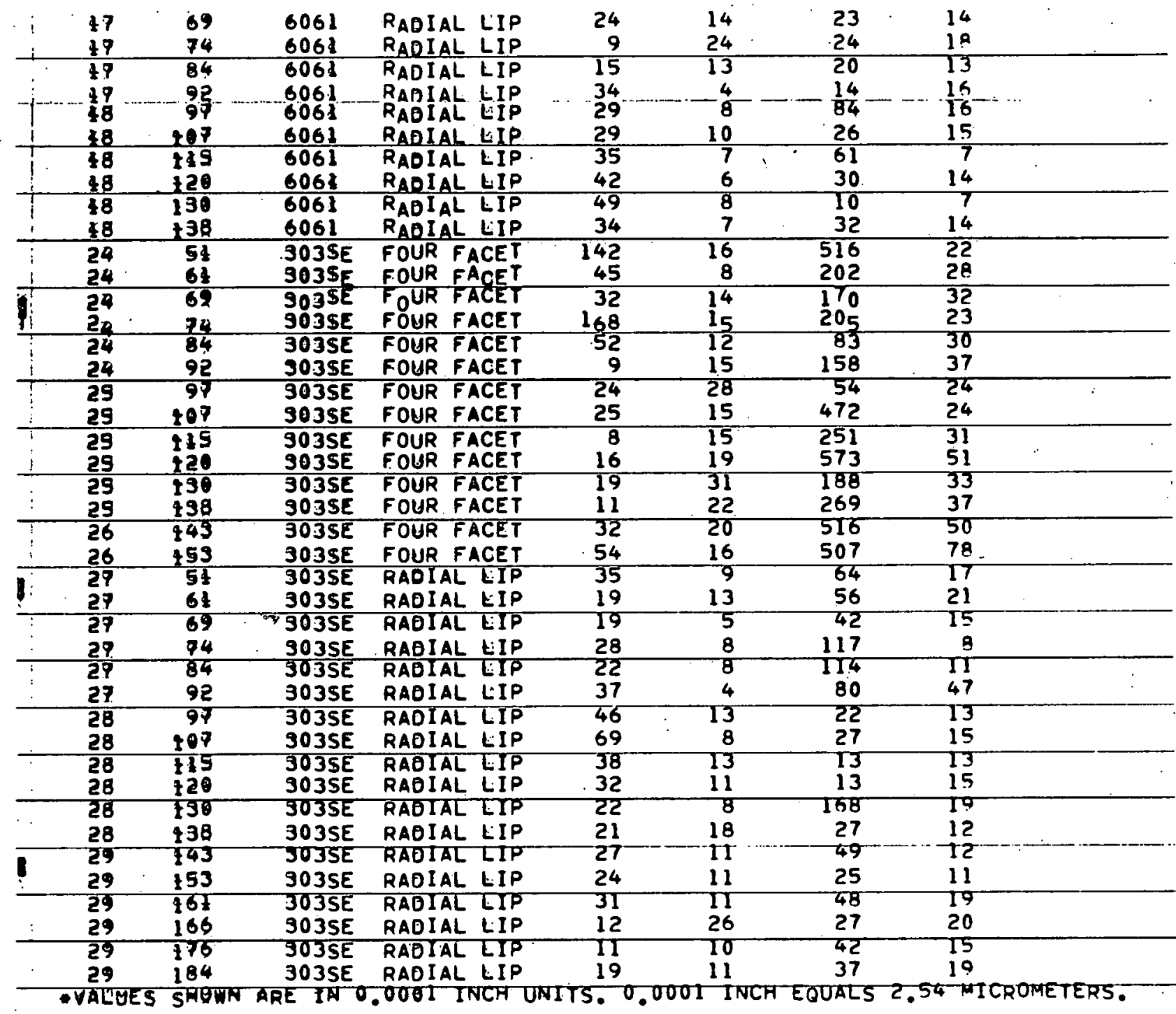


Table A-4. Material Deflection Below Drill Point

\begin{tabular}{|c|c|c|c|c|c|c|}
\hline \multirow{2}{*}{\multicolumn{2}{|c|}{ Workpiece Material }} & \multirow{2}{*}{$\begin{array}{l}\text { Specimen } \\
\text { Number }\end{array}$} & \multicolumn{4}{|l|}{ Feature* } \\
\hline & & & $\stackrel{A}{(\operatorname{Inch}) * *}$ & ${ }_{(\text {Inch })}$ & $\begin{array}{l}\mathrm{C} \\
(\text { Inch })\end{array}$ & (Inch) \\
\hline \multirow[t]{8}{*}{$303 \mathrm{Se}$} & Steel & 11 & 0.0405 & 0.0000 & 0.0165 & \\
\hline & & 12 & 0.0420 & 0.0046 & 0.0154 & \\
\hline & & 13 & 0.0262 & 0.0121 & 0.0090 & \\
\hline & & 14 & 0.0350 & 0.0105 & 0.0112 & \\
\hline & & 23 & 0.0204 & 0.0152 & 0.0059 & \\
\hline & & 24 & 0.0187 & 0.0210 & 0.0090 & 0.0038 \\
\hline & & 25 & 0.0102 & 0.0300 & 0.0075 & 0.0022 \\
\hline & & 26 & 0.0119 & 0.0255 & 0.0068 & 0.0026 \\
\hline \multirow[t]{10}{*}{1018 Steel } & & 3 & 0.0492 & 0.0000 & 0.0161 & \\
\hline & & 4 & 0.0280 & 0.0143 & 0.0105 & 0.0059 \\
\hline & & 9 & 0.0412 & 0.0000 & 0.0122 & \\
\hline & & 10 & 0.0404 & 0.0034 & 0.0094 & \\
\hline & & 15 & 0.0333 & 0.0036 & 0.0068 & \\
\hline & & 16 & 0.0316 & 0.0108 & 0.0085 & 0.0054 \\
\hline & & 21 & 0.0316 & 0.0119 & 0.0088 & 0.0064 \\
\hline & & 22 & 0.0228 & 0.0105 & 0.0022 & 0.0014 \\
\hline & & 27 & 0.0096 & 0.0305 & 0.0068 & 0.0009 \\
\hline & & 28 & 0.0087 & 0.0298 & 0.0064 & 0.0019 \\
\hline
\end{tabular}


Table A-4 Continued. Material Deflection Below Drill Point

\begin{tabular}{|c|c|c|c|c|c|}
\hline \multirow[b]{2}{*}{ Workpiece Material } & \multirow[b]{2}{*}{$\begin{array}{l}\text { Specimen } \\
\text { Number }\end{array}$} & \multicolumn{4}{|l|}{ Feature* } \\
\hline & & 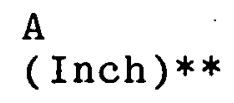 & $\begin{array}{l}\text { B } \\
(\text { Inch })\end{array}$ & $\begin{array}{l}\text { C } \\
\text { (Inch) }\end{array}$ & $\begin{array}{l}\mathrm{D} \\
(\operatorname{Inch})\end{array}$ \\
\hline \multirow[t]{6}{*}{ 17-4PH Stainless steel } & 35 & 0.0272 & 0.0072 & 0.0035 & 0.0015 \\
\hline & 36 & 0.0288 & 0.0014 & 0.0039 & 0.0014 \\
\hline & 37 & 0.0153 & 0.0072 & 0.0000 & 0.0009 \\
\hline & 38 & 0.0145 & 0.0119 & 0.0000 & 0.0017 \\
\hline & 39 & 0.0025 & 0.0122 & 0.0012 & 0.0012 \\
\hline & 40 & 0.0102 & 0.0153 & 0.0000 & 0.0012 \\
\hline \multirow[t]{5}{*}{ 6061-T6 Aluminum } & 18 & 0.0322 & 0.0000 & 0.0051 & 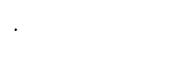 \\
\hline & 19 & 0.0222 & 0.0000 & 0.0131 & \\
\hline & 20 & 0.0222 & 0.0000 & 0.0048 & \\
\hline & 29 & 0.0102 & 0.0031 & 0.0136 & \\
\hline & 30 & 0.0102 & 0.0043 & 0.0017 & \\
\hline
\end{tabular}

* See Figure 33 of this report for definition of Features A, B, C, and D. $* * 0.0001$ inch $=2.54 \mu \mathrm{m}$. 
R. Bulcock, ERDA-KCAO, ID49

G. P. Ford, SLA

K. Gillespie, SLA

R. S. Pinkham, SLA

A. L. Thornton, SLA

A. N. Kenly, Pinellas

J. W. Baker, Rockwell

H. Mercer, Rockwell

K. Thistlewood, Rockwell

J. O. Christy, D/141, 2B31

H. Thompson, D/141, 2B30

W. Johaningsmeir, D/231, 1D40

H. L. Price, D/261, FU34

E. L. Young, D/261, FU34

J. D. Corey, D/554, BD50

L. Stratton, $\mathrm{D} / 554,2 \mathrm{C} 44$

R. F. Pippert, D/700, 1A42

E. F. Felkner, D/752, 1A41

J. D. Johnson, D/752, 1A41

R. P. Frohmberg, D/800, 2A39

J. A. Morrison, D/800; D. D. Oswald, J. P. Dycus, D. R. Wachter, D/822, 2A40

R. K. Albright, D/821, 2A36

J. L. Couchman, F. J. Boyle, B. W. Landes, W. G. Cooper, D/821, 2A36

L. K. Gillespie, D/822, 2A36

G. E. Klement, D/822, 2A36

W. P. McKay, D/822, 2A36

D. P. Roberts, C. E. Spitzkeit, D/823, $1 \mathrm{A27}$

R. W. Lange, D/861, 2A31

R. E. Kessler, D/865, 2C40 